Cephalopods from reef limestone of the Vasalemma Formation, northern Estonia (latest Sandbian, Upper Ordovician) and the establishment of a local warm-water fauna

Kröger, Björn

2018

Kröger , B \& Aubrechtová, M 2018 , ' Cephalopods from reef limestone of the Vasalemma Formation, northern Estonia (latest Sandbian, Upper Ordovician) and the establishment of a local warm-water fauna ', Journal of Systematic Palaeontology , vol. 16 , no. 10 , pp.

799-839 . https://doi.org/10.1080/14772019.2017.1347212

http://hdl.handle.net/10138/308818

https://doi.org/10.1080/14772019.2017.1347212

cc_by_nc_nd

acceptedVersion

Downloaded from Helda, University of Helsinki institutional repository.

This is an electronic reprint of the original article.

This reprint may differ from the original in pagination and typographic detail.

Please cite the original version. 


\title{
Cephalopods from reef limestone of the Vasalemma Formation, northern Estonia (latest Sandbian, Upper Ordovician) and the establishment of a local warm water fauna
}

\author{
Björn Kröger ${ }^{\mathrm{a}^{*}}$ and Martina Aubrechtováa,b \\ ${ }^{a}$ Finnish Museum of Natural History, University of Helsinki, Pohjoinen Rautatiekatu 13, \\ Helsinki, Finland, bjorn.kroger@helsinki.fi [corresponding author], aubrechm@gmail.com ${ }^{b}$ \\ Institute of Geology and Palaeontology, Faculty of Science, Charles University in Prague, \\ Albertov 6, 12843 Praha 2, Czech Republic, aubrechm@gmail.com
}

\begin{abstract}
The cephalopods of the reef limestones of the Vasalemma Formation, northern Estonia, are highly diverse and comprise a number of 22 species, of 10 families and seven orders in a sample of +300 specimens. Most of the specimens were collected from shell concentrations in synsedimentary cavities and are interpreted parautochthonous as washed in from nearby palaeo-habitats. Nearly all of the shells are fragmented and nearly $15 \%$ are partially encrusted by epibionts. The assemblage is dominated by small (mostly less than $30 \mathrm{~mm}$ wide) straight shelled actinocerids and orthocerids, additionally coiled tarphycerid are common. The higher taxonomic composition of the Vasalemma cephalopod assemblage with a dominance of actinocerids and an absence of endocerids is in agreement with an interpretation of the depositional environment under a warm water (tropical or subtropical) shallow subtidal regime. At species level the assemblage is highly endemic, but the generic composition allows for a statistical comparison with other faunas. A cluster analysis of contemporary assemblages reveals a high degree of similarity with late Sandbian cephalopod faunas of epicontinental Laurentia. The palaeogeographical distribution pattern is similar than in brachiopods, which supports earlier interpretations of these clusters as mainly controlled by water temperature and depositional depth. Several of the Vasalemma genera became conspicuous elements of epicontinental Laurentia during the Katian, which emphasizes that immigration toward Laurentia was an important factor in Late Ordovician diversity dynamics. Of the described taxa, the following are new: Beloitoceras cautis sp. nov., Curtoceras abditus sp. nov., Hemibeloitoceras arduum sp. nov., H. molis sp. nov., Hoeloceras muroni sp.nov., Isorthoceras cavi sp. nov., I. maris sp. nov., I. padisense sp. nov., I. vexilli sp. nov., Ordogeisonoceras tartuensis sp. nov., Orthonybyoceras isakari sp. nov., O. moisense sp. nov., Pleurorthoceras organi sp. nov., Rummoceras rummuensis gen. nov. et sp. nov., Trocholites gennadii sp. nov.
\end{abstract}

Keywords: Katian-Sandbian boundary, GICE, Keila Regional Stage, palaeogeography, bioherm.

\section{Introduction}

Biogenic reefs are an important part of the carbonate platform of the Late Ordovician Baltic Basin and adjacent areas of Baltoscandia. During the Late Ordovician framework reefs became widespread in the shallower parts of the basin and large mud mounds grew in a broad belt across the deeper parts of the basin (e.g. Tuuling \& Flodén 2000; Kröger et al. 2016). The framework reefs and mud mounds contain a highly diverse fauna of reef dwellers and associated taxa, which is often poorly known and in only few cases explicitely described.

The most complete faunal documentation currently exists for the mud mounds of the Boda Limestone Formation, late Katian to early Hirnantian, Sweden. Here, dozens of monographed species of bivalves, brachiopods, bryozoans, cephalopods, echinoderms, and trilobites indicate 
that the bioherms were diversity hot spots for a wide range of sessile and motile organisms (see reviews in Ebbestad \& Högström 2007; Kröger \& Ebbestad 2014).

The oldest horizon with widespread Baltoscandian reef and mound development is the late Sandbian-early Katian boundary interval. Mud mounds of this time interval occur in central Sweden (Kullsberg Limestone Formation, Ebbestad \& Högström 2007) and in a wide belt that ranges from subsurface Gotland to northern Estonia (see review in Kröger et al. 2016). Framework reefs occur in Norway (Mjøsa and Steinvika formations, e.g. Opalinski \& Harland 1981), and northern Estonia (Vasalemma Formation, Kröger et al. 2014a).

The late Sandbian-early Katian boundary interval is exceptional because it records drastic faunal changes, volcanic events, and oceanic and climatic disturbances at global scale and the processes and mechanisms behind the events are discussed highly controversially (e.g. Patzkowsky et al. 1997; Young et al. 2005, 2008, 2010; Bergström et al. 2010; Pancost et al. 2013; Sell et al. 2015; Quinton et al. 2015).

The reef evolution and the associated faunal changes are an important aspect of these events in the Baltoscandian region. The stratigraphy and depositional history of late Sandbian-early Katian reefs is comparatively well understood (Opalinski \& Harland 1981; Calner et al. 2010; Kröger et al. 2014a). In contrast, the fossil inventory of the late Sandbian-early Katian bioherms is only insufficiently known although comprehensive museum collections exist and new collections are easy to conduct.

The cephalopods are here of particular interest because they are unusually abundant and rich and because previous investigations have shown that the level of endemism is lower than in other groups. Cephalopods are privileged for palaeogeographical and paleoecological analyses of reef related motile organisms (Kröger 2013a). Most of the published paleogeographical faunal analyses of the late Sandbian-early Katian boundary interval are based on brachiopods (e.g. Hansen et al. 2008, 2009; Candela 2015; Sohrabi \& Jin 2013). A comparison of the cephalopod record with brachiopod occurrence pattern provides an independent test of these paleogeographical and pelaeoecological models of faunal distribution.

Few cephalopods of the Vasalemma Formation have been described in the past (Balashov 1953; Stumbur 1962; Kröger \& Isakar 2006). Our own collections and existing museum collections provide a material of more than 300 specimens, which are described herein. The taxonomic description of the Vasalemma cephalopods is the basis for a diversity analysis and allows for a comparison of the assemblage with other reef related and time equivalent cephalopod assemblages.

\section{Studied Material and Geological Setting}

\section{Abbreviations}

NM L: National Museum, Prague, Czech Republic, GIT: Tallinn University of Technology, Institute of Geology, Tallinn, Estonia, TUG: University of Tartu Natural History Museum, Tartu, Estonia, LGU: University of St. Peterburg, Institute of Historical Geology, St. Peterburg, Russia. 


\section{Studied material}

About 355 cephalopod specimens from the reefs of the Vasalemma Formation (for details of localities see Data Supplement 1, for list of specimens see Data Supplement 2) were studied. The material was collected mainly by Heino Stumbur in the 1950s and by joint collections of BK and Mare Isakar in 2007-2015. All of the material is kept at GIT and TUG in Estonia. Five specimens of the tarphycerid genus Discoceras also come from the private collection of M. Kubajko (specimens now held at the National Museum in Prague, Czech Republic).

\section{Geological Setting and Stratigraphy}

The Vasalemma Formation is an up to $15 \mathrm{~m}$ thick succession of biodetrital (mainly echinoderm) grainstone and reef limestone, which crops out in a narrow c. $5 \mathrm{~km}$ wide and $20 \mathrm{~km}$ long NE-SW stretching belt in northwestern Estonia. (Fig. 1). The limestone was first described in a stratigraphical context by Eichwald (1854) and Schmidt (1881) and named 'Hemicosmitenkalk' or 'Wasalemm'sche Schicht'. The reefs of the Vasalemma Formation were for the first time explicitely identified by Raymond (1916). A general review and revision of the stratigraphy and depositional setting of the formation and a detailed description of the reefs was published by Kröger et al. (2014a, b, 2016).

The reefs of the Vasalemma Formation reach diametres from a few metres up to $50 \mathrm{~m}$ and are composed of (1) a bryozoan framestone-bindstone, (2) an echinoderm bindstone, (3) a receptaculitid-bryozoan-microbial framestone, and (4) a tabulate bafflestone. Large parts of the matrix display a characteristic polymud-fabric with areas with different densities of micrite and often with clotted micritic pattern. Except for the tabulate bafflestone, all facies types occur in the youngest and oldest intervals of reef growth (Kröger et al. 2016).

The exact timing of the Vasalemma Formation and and the reef development is discussed controversially in the literature. The problems are partly caused by a lack of consenus concerning the exact position of the boundary between the Keila and Oandu regional stages (see Ainsaar et al. 1999, 2010; Bergström et al. 2011; Kaljo et al. 2004) and by a lack of biostratigraphically indicative taxa in the Vasalemma Formation. Chemostratigraphy, based on $\delta^{13} \mathrm{C}$ isotope curves, provides an additional tool for regional and supra-regional correlation. New data presented by Kröger et al. (2014a, b) provided evidence that the Vasalemma Formation represents the rising limb of a carbon isotope excursion that was widely interpreted as correlative of a Guttenberg Carbon Isotope Excursion (GICE) of North America (e.g. Ainsaar et al. 2010; Bergström et al. 2010, 2012). This time interval, in turn, can be correlated with the basal Katian of Goldman et al. (2007). In previous reviews, accordingly, the Vasalemma Formation was correlated with the basal Katian (Kröger et al. 2014a).

A refined absolute dating of the late Sandbian-early Katian K-bentonite layers in North America and geochemical K-bentonite fingerprinting methods reveal that the GICE is part of a complex succession of carbon isotope excursions in eastern North America which ranges across the late Sandbian-early Katian boundary interval (Sell et al. 2013, 2015). The Spechts Ferry Carbon Isotope Excursion represents the earlier peak and the GICE represents the late peak of that interval. The Spechts Ferry excursion is consistently interpreted as late Sandbian (e.g. Bergström et al. 2010, Sell et al. 2015).

New absolute datings indicate that the Baltoscandian Kinnekulle K-bentonite, which marks the base of the Keila Regional Stage, and which was partly correlated with the Millbrig K-bentonite in eastern North America (see e.g. Bergström et al. 2010), is older than any of the major North 
American late Sandbian-early Katian K-bentonites. Hence, in the absence of any indicative taxa, the initial onset of the isotope excursion in the Keila Stage deposits in the more complete sections of the Baltic area may rather be correlated with the Spechts Ferry excursion than with the GICE, sensu stricto. This interpretation would allow to restrict the Keila Regional Stage and the Vasalemma Formation to the late Sandbian Stage. Moreover, this interpretation would allow for a more consistent direct correlation of the prominent M4/M5 sequence boundary of eastern North America (at the base of the Lexington Limestone, sensu Patzkowsky et al. (1997) and Sell et al. (2015) with the major boundary of the depositional sequences VII/VIII (sensu Dronov et al. 2011) in Estonia as suggested already by Ainsaar et al. (2004). Consequently, herein we place the Vasalemma Formation (except for the Saku Member, see Kröger et al. 2014b) within the late Sandbian Stage (Fig. 2).

\section{Methods}

The specimens were studied using a stereoscopic microscope Olympus SZX7 (ACH 1x) and a stereoscopic microscope Olympus SZX16 (0.5xPF) with attached camera. The measurements were taken either by a caliper or calibrated measure inserted into the microscope. Polished median sections of selected specimens were prepared and photographed. For photographing of surficial structures, selected specimens were coated in ammonium chloride. Nikon D5300 and Canon EOS 6D cameras were used for photographing. The photographs were finished in CorelDRAW X5 and Photoshop CS5.

If possible, quantitative parametres were used for the morphological descriptions of the specimens (Table 1). Parametres of coiled specimens were measured and calculated according to Korn \& Klug $(2003,2007)$. The morphological terms of the cephalopod shell are adopted from Kröger (2004) and Kröger \& Isakar (2006). The denomination of the septal necks with terms such as orthochoanitic, suborthochoanitic, cyrtochoanitic and loxochoanitic is not always unambiguous when the septal neck is very short. This can create some cursory conflicts between existing genus and species diagnoses and specific descriptions. For a discussion of this problem see Kröger \& Isakar (2006: 140, 153).

The diversity measures and the measures of evenness are calculated based on subsampled richness after the shareholder quorum subsampling method of Alroy (2010) using R and the functions of the version 3.3 provided by John Alroy in 2011 (http://bio.mq. edu.au/ jalroy/SQS.html). The taxonomic distinctness (Clarke \& Warwick 1999) was calculated with a step length of 1 . This is justified in the case of Palaeozoic cephalopods because in all taxa, a fixed scheme of species, genus, family, order is used (see e.g. Moore 1964). We accepted the Barrandeocerida and placed Vasalemmoceras Stumbur, 1962 within this order, but did not accept the Pseudorthocerida and reassigned the families to the Orthocerida. The multivariate analyses were executed with the $\mathrm{R}$ functions of Vegan (Oksanen et al. 2013). A correspondence analysis as implemented in the function cca (all cephalopod orders are the variables of the analysis) of vegan was preferred herein as ordination method because it results in a relative ordering of the assemblages (see Oksanen et al. 2013). The data for the comparison of the cephalopod assemblages are compiled from the literature (see Data Supplement 3).

\section{Systematic palaeontology}


Order Cyrtocerinida Mutvei, 2015

Family Cyrtocerinidae Flower, 1946

Genus Rummoceras gen. nov.

Type species. Rummoceras rummuensis sp. nov., Rummu, near Vasalemma, northern Estonia, Vasalemma Formation, Keila Regional Stage.

Diagnosis. Orthoconic or slightly cyrtoconic cyrtocerinid with an angle of expansion of c. $11^{\circ}$, circular shape of cross-section, and orthochoanitic to loxochoanitic septal necks.

Derivation of name. Refering to the type locality.

Occurrence. As for the type species, by monotypy.

Remarks. The strongly concave, and strongly thickened connecting rings, which are combined with a relatively high angle of expansion qualify the new genus as a cyrtocerinid. Rummoceras gen. nov. is unique within the family in having a straight shell with nearly circular cross-section and in having relatively long loxochoanitic septal necks. Rummoceras gen. nov. differs from bathmocerids in lacking endosiphuncular lamellae, characteristic for this family (see Mutvei, 2015)

Rummoceras rummuensis gen. nov. et $\mathrm{sp}$. nov.

(Figs 3, 4, 5)

Holotype. Specimen TUG 1709-31 (by monotypy).

Diagnosis. As for the genus.

Derivation of name. Referring to the type locality.

Material. Known from the holotype, only.

Type locality and horizon. Rummu, near Vasalemma, Vasalemma Formation, Keila Regional Stage, northern Estonia.

Description. The holotype is an isolated part of a phragmocone, which was naturally cut in lateral direction at the siphuncular side of the shell (Figs 3A, B). The preserved length is $84 \mathrm{~mm}$, the maximum diametre is $41 \mathrm{~mm}$ and the minimum diametre is $25 \mathrm{~mm}$. The shell is straight or slightly curved with siphuncle on convex side of curvature and with a circular cross-section. The angle of expansion is $11^{\circ}$. The sutures are straight and directly transverse. Eighteen to twenty

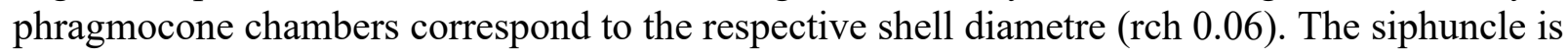
marginal (this can be deduced from the position of the siphuncle and its preserved maximum diameter, see Figs 3D, 5). The cross-section of the siphuncle is circular or slightly depressed. Its diametre corresponds to 0.3 of the corresponding phragmocone diametre. The septal necks (Figs $3 \mathrm{~A}, \mathrm{C}, 4 \mathrm{C}$ ) are ortho- to loxochoanitic and in length correspond to 0.3 of the total height of the respective siphuncular segment. The connecting rings (Figs 3A, C, 4C) are thin, almost tubular (scr 5.8, rss 0.97), with projections into the siphuncle . The projections are thickest at about half the height of the siphuncular segment. The living chamber is not preserved. The apex is not preserved. The sculpture is poorly preserved but the shell was probably smooth. The cameral and endosiphuncular deposits have not been observed.

Remarks. As for the genus.

Order Tarphycerida Flower in Flower \& Kummel, 1950

Family Trocholitidae Chapman, 1857

Genus Trocholites Conrad, 1838

Type species. Trocholites ammonius Conrad, 1838, from the Middle Ordovician of Trenton, USA, by original designation. 
Diagnosis (after Frey 1995). Shell small, generally less than $100 \mathrm{~mm}$ in diametre, gradually expanding, subdiscoidal in shape, five or more volutions, a body chamber one-half to threefourths of a volution in length that does not diverge from preceding whorl, whorl cross-section strongly depressed, broadly reniform, weakly impressed dorsally, rounded across venter and flanks, umbilicus wide, umbilical perforation small, siphuncle tubular, narrow in diametre, segment diametres from one-fifth to one-sixth the diametre of the whorl, dorsal or subdorsal in position in all stages of growth, septal necks short, ortho- and/or loxochoanitic, connecting rings thin, thickening adorally with ontogeny, surface sculpture of fasciculate growth lines or bands and raised ribs that form ventral sinuses.

Remarks. See discussion under Curtoceras Ulrich, Foerste, Miller \& Furnish, 1942.

Trocholites gennadii sp. nov.

(Figs 6A, B, 7A, D, 8D, 9B)

Holotype. Specimen TUG 939-71, herein figured at Figs 6A, B, 7A, D, 8D, 9B.

Type locality and horizon. Vasalemma, northern Estonia, Vasalemma Formation, Keila Regional Stage.

Diagnosis. Trocholites with adult shell diametre of slightly more than $30 \mathrm{~mm}$, with faint reticulate sculpture, relatively low WER (c. $2^{\circ}$ ), relatively high UWI (c. 0.5$)$, and a strongly depressed whorl cross-section (WWI c. 1.8), with a wide marginal to submarginal siphuncle with a diametre of 0.28 of the respective whorl height. Siphuncular position between dorsum and center of the shell with rsp of c. 0.86 .

Derivation of name. Derivation of name. Named after Gennadi Baranov, a skilled photographer and active collector at the GIT.

Material. Holotype and GIT 222-669.

Occurence. Type locality and horizon, only.

Description. The holotype is a fragment of a phragmocone and a body chamber. The shell is in total $32 \mathrm{~mm}$ in diametre. The last whorl is $16 \mathrm{~mm}$ in width and $9 \mathrm{~mm}$ in height. The aperture of the living chamber is not preserved, the preserved part equals in length c. 0.25 of the last whorl. The individual whorls do not overlap each other (UWI 0.5) and are slightly depressed in crosssection (WWI 1.8) (Fig. 8D). The whorl expands with a WER of 2. The sutures are straight and directly transverse. About four phragmocone chambers correspond to the respective whorl height (rch 0.26). The last phragmocone chamber is significantly shorter (rch 0.1) (Fig. 7A). The siphuncle (Figs 7D, 9B) is marginal, close to the dorsal shell wall ( $r s p ~ 0.86)$. The cross-section of the siphuncle is circular or slightly compressed with a diametre of 0.3 of the respective phragmocone diametre. Septal necks are loxochoanitic, the connecting rings are in shape concavo-convex ventrally and concave dorsally (Figs Figs 7D, 9B). They are thin and homogenous in the last five phragmocone chambers (Fig 7D). In earlier phragmocone chambers the connecting rings are thickened on their outer surface (Fig 7D). Their outer layer is finegrained, micro-sparitic, without any visible internal structure. Their inner layer is thin and dark in colour, without any visible internal structure. The shell is sculptured with faint, slightly undulating longitudinal (3 per $\mathrm{mm}$ ) and transverse lirae (10 per $\mathrm{mm}$ ) (Figs 6A, B).

Specimen GIT 222-669 is a small fragment of a phragmocone, $24 \mathrm{~mm}$ in diametre. The last whorl is $11 \mathrm{~mm}$ in width and $9.5 \mathrm{~mm}$ in height. The living chamber is not preserved. The individual whorls do not overlap each other (UWI 0.3) and are slightly depressed in cross-section (WWI 1.13). The whorl expands with a WER of 1.7.

Remarks. Trocholites gennadii sp. nov. is nearly similar in WER and UWI to Trocholites contractus Schröder, 1891, known from erratic boulders of Uhaku Regional Stage strata (Middle 
Ordovician) in the Baltic region and from Norway (Sweet 1958; Neben \& Krüger 1971; Dzik 1984), and can be compared with Trocholites faberi Foerste, 1930 from the Trentonian Regional Stage (Sandbian Stage) of Kentucky, USA (Frey 1995). However, T. contractus differs in being significantly more depressed (WWI 2.25) and T. faberi reaches an adult size of up to $90 \mathrm{~mm}$ (Frey 1995). Note, that the reduced distance between the last two septa of the holotype of $T$. gennadii sp. nov. indicates near adult size of the specimen. The reticulate shell sculpture of $T$. gennadii sp. nov. resembles that of Trocholites ammonius Conrad, 1838 and Trocholites planorbiformis Conrad, 1842 from early Katian strata of the eastern USA. T. gennadii sp. nov. differs from the latter two species in having a lower WER and a higher UWI (Fig. 10).

Genus Curtoceras Ulrich, Foerste, Miller \& Furnish, 1942

Type species. Lituites eatoni Whitfield, 1886, from Fort Cassin Limestone, Early Ordovician, USA, by subsequent designation by Ulrich et al. (1942).

Diagnosis (compiled from Ulrich et al. 1942 and Furnish \& Glenister 1964). Gradually expanded, subdiscoidal in shape, with half of the fully mature body chamber or more divergent from the preceding whorl, whorl cross-section with width and height nearly equidimensional, weakly impressed dorsally, rounded across venter and flanks, siphuncle tubular, ventral in initial chamber, subdorsal after one volution, septal necks orthochoanitic, connecting rings thin, thickening adorally with ontogeny, surface smooth or with prominent striae or low ribs that form ventral sinuses.

Remarks. The generic distinction between Trocholites and Curtoceras Ulrich, Foerste, Miller \& Furnish, 1942, is problematic. Curtoceras, originally, was distinguished from Trocholites because the shell of Trocholites is 'more prominently ornamented and the whorls are broader' (Ulrich et al. 1942, p. 70). Additionally the detachment of the adult body chamber in Curtoceras as a distinguishing criterion is listed (Furnish \& Glenister 1964). This distinction is unambiguous when comparing the type species of the two genera, but it becomes problematic with species that that are transitional between the two extremes. Compared with Curtoceras, the internal characters of Trocholites and the early growth stages are poorly known. Nothing is known from both genera about ontogenetic trends in the shape the whorl cross-section. This makes a direct comparison and genus determination difficult.

Generally, authors tend to place trocholitids with strongly depressed whorl cross-sections (WWI c. 2 and above) into Trocholites, and trocholitids with nearly equidimensional whorl cross-sections (WWI c. 1) into Curtoceras (comp. e.g. Balashov 1953 and Sweet 1958). Herein, we follow this practice. Curtoceras abditus sp. nov. is described herein, with a nearly equidistal whorl cross-section (WWI 1.2) and a pronounced ornamentation.

\section{Curtoceras abditus sp. nov.}

(Figs 6C, 8F)

Holotype. Specimen GIT 222-676 (by monotypy).

Type locality and horizon. Vasalemma, northern Estonia, Vasalemma Formation, Keila

Regional Stage.

Diagnosis. Curtoceras with a relatively weakly depressed whorl cross-section WWI (c. 1.2) and high WER (c. 2.3), shell sculptured by faint longitudinal lirae and prominent transverse striae (c. 2 per $\mathrm{mm})$.

Derivation of name. From Latin, abditus, the hidden.

Material. Known from the holotype, only. 
Description. The single specimen is a fragment of the phragmocone and part of the body chamber. The shell is $26 \mathrm{~mm}$ in maximum diametre with WER of c. 2.4. The whorl cross-section is depressed (Fig. 8F) with a width of $13 \mathrm{~mm}$ and a height of c. $10 \mathrm{~mm}$ (WWI 1.2). The shell is sculptured by faint longitudinal lirae $(22$ per $\mathrm{mm}$ ) and pronounced transverse striae (distance c. 3 per $\mathrm{mm}$ ) that form shallow sinus on the ventral side of the shell (Fig. 6C). The siphuncle is 1.3 $\mathrm{mm}$ in diameter, where the whorl height is $7.4 \mathrm{~mm}$ and close to the dorsal side $(0.2 \mathrm{~mm})$.

Remarks. Curtoceras abditus sp. nov. is similar in whorl expansion to Trocholites depressus (Eichwald, 1840) from the Uhaku Regional Stage of Estonia, Trocholites ammonius Conrad, 1838 from the Trenton limestone, New York, USA, and to Trocholites hospes (Remelé, 1880) from the Middle Ordovician of the Baltic Region (Fig. 10), but differs from these species in having a significantly less depressed whorl cross-section. Trocholites contractus Schröder, 1891 from the Uhaku Regional Stage is similar to C. abditus sp. nov. in possessing surficial ribs but differs in having a lower whorl expansion WER (1.8) and a more depressed whorl cross-section (WWI 2.25) (Fig. 10A). C. abditus sp. nov. differs from other species of Curtoceras in combining a pronounced transverse ornamentation with a relatively strongly depressed whorl cross-section (WWI 1.2) (Fig. 10A).

Genus Discoceras Barrande, 1867

Type species. Clymenia antiquissima Eichwald, 1842, Kärdla, Island of Hiiumaa, Estonia, Nabala to Pirgu regional stages, upper Katian, Upper Ordovician.

Diagnosis (adapted after Furnish \& Glenister 1964). Gradually expanding ribbed or smooth forms characterized by a slight to moderate whorl impression, circular to subquadrate whorl cross-section, central position of siphuncle in initial half-volution, marginodorsal in succeeding 1.5 to 2 whorls, subdorsal at maturity, and thick, layered connecting rings.

Discoceras rarospira (Eichwald, 1860)

(Figs 8C, 11)

1840 Clymenia rarospirai Eichwald: 108.

1860 Clymenia rarospira Eichwald, Eichwald: 1302, pl. 50, figs 2a, b.

1953 Schroederoceras rarospira (Eichw.), Balashov: 251-2, pl.6, figs 4a,b.

1958 Discoceras rarospira (Eichwald), Sweet: 103, 114-5, pl. 17, fig.6, text-fig.13B.

1962 Schroederoceras rarospira (Eichwald), Balashov: 9, fig. 3.

1962 Rectanguloceras rarospira Eichwald, Stumbur: 137, 142.

1964 Schroederoceras rarospira (Eichwald), Balashov: pl. 9, fig. 3.

2002 Discoceras cf. Discoceras rarospira (Eichwald), 1860, Zhang \& Chen: 83, pl. 3, fig. 2.

Holotype. LGU 1/1125 collection of K. E. I. von Eichwald (1775-1876), by subsequent designation by Balashov (1953) from Haljala, Estonia, type horizon questionably Uhaku Regional Stage (see Balashov 1953, Stumbur 1962) (not studied herein).

Material. Two specimens, GIT 222-95 and TUG 1585-34, from locality Vasalemma and Rummu, respectively.

Occurrence. Arnestad Formation, Upper Ordovician, Oslo-Asker district, Norway (Sweet 1958), Haljala, Keila, Rakvere, and Nabala Regional Stages, Upper Ordovician, Estonia (Stumbur 1962), and from the upper part of the Guniutan Formation of Yunnan, Middle Ordovician, South China (Zhang \& Chen 2002). 
Diagnosis (compiled from Balashov 1953). Shape of the whorl cross-section nearly circular in early ontogeny, later in ontogeny sub-quadratic with flattened venter and rounded lateral sides (WWI 0.9-1), shell surface sculptured by slightly frilled transverse ribs that form a deep sinus on the venter, sutures with shallow lateral lobe, siphuncle with diametre of $0.16-0.19$ of the respective whorl height, close to the dorsal margin of the shell (rsp 0.9-0.95), with orthochoanitic septal necks.

Description. Specimen GIT 222-95 with a slightly depressed, sub-quadratic whorl cross-section (Fig. 8C). The whorl is c. $20 \mathrm{~mm}$ in width and c. $19 \mathrm{~mm}$ in height (WWI c. 1). In late growth stages the whorl cross-section becomes more depressed. The sutures are directly transverse, with a lateral lobe. Six phragmocone chambers correspond to the respective whorl height (rch 0.16). The siphuncle is dorsal, marginal to submarginal (rsp 0.86), with a circular cross-section, and a diametre of c. 0.2 of the respective shell cross-section diametre. The shell sculpture consists of irregularly spaced crenulated ribs.

TUG 1585-34, is a phragmocone with a maximum diametre of c. $68 \mathrm{~mm}$. The latest whorl is $25 \mathrm{~mm}$ in width and $25 \mathrm{~mm}$ in height. The shell is evolute, the individual whorls do not overlap each other (UWI 0.4, IZR 0.04) (Fig. 11B). The shape of the whorl cross-section is subquadratic with flattened venter and flattened lateral sides. The whorl expansion (WER) is c. 2.4. The siphuncle is dorsal, marginal but not in contact with the shell wall ( $r s p$ 0.9), it has a circular cross-section and its diametre is 0.16 of the respective shell cross-section diametre. The shell is sculptured by slightly frilled transverse ribs with a deep lobe on the ventral side of the shell. The ribs are regularly spaced.

Remarks. Herein we emended the original diagnosis of Discoceras rarospira in order to include ontogenetic changes of the shell shape. D. rarospira is similar to Discoceras ievense (Balashov, 1953) with respect of the flattened venter of the whorl cross-section, with WWI, which is nearly 1 (Fig. 11C), and with whorl expansion rate (Fig. 11A). The two species differ in details of the whorl cross-section. The lateral side of the whorl cross-section are more flattened and the transition between flanks and venter is more sharp in D. ievense. Discoceras vesenbergense (Balashov, 1953) (sic!) resembles D. rarospira and D. ievense in the general shape of the crosssection but the former differs in having a significantly more depressed whorl cross-section (WWI c. 1.3) (Fig. 11C). Discoceras rarospira (Eichwald, 1860) differs from Discoceras vasalemmense (Balashov, 1953) in having a flattened venter and a slightly higher WER (Figs 8C, 11A).

Discoceras vasalemmense (Balashov, 1953)

(Figs 7B-C, E, 12)

1953 Schroederoceras vasalemmense sp. n. Balashov: 212 (nomen nudum).

1958 Discoceras vasalemmense (Balaschov), Sweet: 102, text-fig.13K.

1962 Rectanguloceras vasalemmense (Balashov, 1953), Stumbur: 142.

Diagnosis (emended). Discoceras with a circular to compressed ovoid whorl cross-section in early growth stages and compressed heart-shaped whorl cross-section in later growth stages, WWI decreasing with increasing shell diametre from $>1$ to $<0.8$, WER decreasing with increasing shell diametre from $>3$ to c. 2 , UWI between $0.14-0.45$, decreasing with increasing shell diametre, in early ontogenetic growth stage sculptured by regular, slightly frilled, straight, transverse ribs with faint longitudinal lirae, in later ontogenetic growth stage sculptured by irregularly spaced crenulated ribs. 
Material. Thirty-nine specimens at the UT, GIT and NM, from localities Rummu and Vasalemma, northern Estonia, Vasalemma. Formation, Keila Regional Stage (see Data Supplement 2).

Occurrence. Vasalemma Formation, Keila Regional Stage.

Description. None of the specimens probably represents an adult specimen. The largest specimen in the collection (NM L 46530) has a maximum diametre of c. $78 \mathrm{~mm}$. About three whorls are preserved in largest specimens. The third whorl ranges from 9-25 in width (median=12, $\mathrm{n}=15$ ) and from $10-24 \mathrm{~mm}$ in height (median=15, $\mathrm{n}=24)$. The shell is almost evolute, the individual whorls do not overlap each other significantly (UWI 0.14-0.45, median $=0.3, \mathrm{n}=36$, IZR $0.01-0.4$, median $=0.2, \mathrm{n}=27$ ). The shape of the whorl cross-section changes with ontogeny from circular to compressed ovoid or slightly heart-shaped (WWI decreases with increasing shell diametre, see Figs 7C, 8A-B, 11C, 13A), in late growth stages the whorl cross-section is heart-shaped with a narrow ventral side. The whorl expansion rate (WER) is 2-3.3 (median 2.65, $\mathrm{n}=36$ ). The whorl expansion declines with increasing diametre of the shell from $>2.5$ in early whorls to $<2.2$ in specimens with diametres larger than $35 \mathrm{~mm}$ in diametre (Fig. 11A). The sutures are straight and directly transverse with five to six phragmocone chambers per respective shell diametre. The siphuncle is dorsal, marginal but not in contact with the shell wall ( $\operatorname{rsp} 0.93-0.83$, median $=0.88, \mathrm{n}=8$ ), it has a circular cross-section and its diametre is $0.14-0.16$ of the respective whorl height. The septal necks are short orthochoanitic, the connecting rings are thin, homogenous and tubular (Figs 7B, 9A). The shell is sculptured with frilled transverse ribs with a deep lobe on the ventral side of the shell (Fig. 12). In early growth stages, the ribs are regularly spaced (TUG 1585-39, GIT 426-157, Fig. 12A), and a fine, longitudinal sculpture (TUG 939-76, GIT 426-148, Fig. 12D) occurs (first c. 1.5 whorl). During later growth stages, the ribs are strongly crenulated, coarse, and irregularly spaced (Fig. 12D). The internal structure of the initial shell part is preserved in specimen TUG 939-64 (Figs $7 \mathrm{~B}, \mathrm{E})$. The most apical part is curved, depressed (1 $\mathrm{mm}$ in height and $2.5 \mathrm{~mm}$ in width), without a constriction. The caecum is compressed, ovoid in shape $(0.7 \mathrm{~mm}$ in height, $0.5 \mathrm{in}$ width, ratio $0.7)$, and in position shifted towards the ventral part of the shell. The second phragmocone chamber is $1 \mathrm{~mm}$ in height and $3 \mathrm{~mm}$ in width (rch 0.4), the siphuncle is central in position, tubular in shape. In the third phragmocone chamber, the siphuncle is subcentral and tubular in shape. From the fourth phragmocone chamber on, the siphuncle is dorsal in position. At the position of $\mathrm{c}$. one whorl, the phragmocone chambers shorten to relative heights as described above.

Remarks. The designation of the specimens, described above, is somewhat problematic, because the holotype and only specimen described by Balashov (1953) is not available. Furthermore, the type locality given is Rakvere, northern Estonia, which is in conflict with a Vasalemma Formation occurrence, because at Rakvere the Vasalemma Formation does not occur. However, we decide to include our specimens, which form a coherent morphological group, to assign to $D$. vasalemmense because of the close similarity and uniqueness of the conch cross section and of the similarity of the transverse ornamentation. The original diagnosis of Balashov (1953) is emended herein, in order to incorporate intraspecific variability. The original diagnosis of Balashov (1953) was based on a single slightly taphonomically distortet specimen (see Balashov, 1953, tab. 9, fig. 4a), only. The specimens available at the TUG, GIT and NM allowed for a better evaluation of ontogenetic and intraspecific variation of shell parametres (Figs 8A-B, 11, $12 \mathrm{~A}-\mathrm{F}, 13 \mathrm{~A}$ ). All specimens are characterised by a very fine longitudinal ornamentation (Fig. $12 \mathrm{~B}, \mathrm{E})$, and/or crenulation which varies from specimen to specimen. Specimen GIT 426-148 
(Fig. 12F) is extreme in having a crenulated ornamention already during earliest growth stages and is placed within $D$. vasalemmense until more and better preserved similar variants are known.

Discoceras rarospira (Eichwald, 1860), which is a widespread species of Discoceras in Middle and early Late Ordovician strata of Baltoscandia and South China (Balashov 1953; Sweet 1958; Zhang \& Chen, 2002), differs in having a less compressed, adult cross-section with a flattened venter. Discoceras ievense (Balashov, 1953) from Jõhvi Regional Substage (Sandbian Stage) of Estonia differs in having a sub-quadratic slightly depressed whorl cross-section and a larger relative diametre of the siphuncle.

Order Barrandeocerida Flower in Flower \& Kummel, 1950

Family Barrandeoceratidae Foerste, 1925

Genus Vasalemmoceras Stumbur, 1962

Type species. Vasalemmoceras tolerabile Stumbur, 1962, Vasalemma, northwest Estonia, Keila Regional Stage.

Diagnosis (emended). Barrandeocerid with a compressed planispirally coiled shell, which becomes gyroconic after c. one volution, initial c. $4 \mathrm{~mm}$ of the shell weakly cyrtoconic, first whorl with whorls in contact but not overlapping each other, with large umbilical window of c. 4 $\mathrm{mm}$, the whorl cross-section elliptically compressed with WWI of c. 0.8 , WER of c. 3, sutures straight or with shallow lateral lobes, phragmocone chambers short (rch c. 0.12), siphuncle narrow (0.04-0.1 relative to whorl height), ventral, in contact with the shell wall, septal necks short, suborthochoanitic, connecting rings thick, tubular, shell surface smooth with fine transverse growth lines producing sharp ventral sinus.

Remarks. The genus diagnosis is emended based on new observations on the type material that allow the determination of characters of early ontogeny and details of the internal morphology. Vasalemmoceras has short, suborthochoanitic septal necks and thick, tubular connecting rings in which two layers of different composition can be observed. The inner of these layers is a continuation of the septal necks. This corresponds to the calcified-perforate type of connecting rings as described and illustrated by Mutvei \& Dunca (2011) and Mutvei (2015) for orthocerids and barrandeocerids.

Dzik (1984) synonymised Vasalemmoceras with the Charactoceras Foerste, 1924 (Upper Ordovician of Laurentia and Baltica). However, Charactoceras differs from Vasalemmoceras because it has ventral and dorsal lobes on the sutures, surficial ribs in early ontogenetic stages, a less marginal siphuncle and expanded connecting rings. Avilionella Flower, 1952 from the upper Chazyan, Valcour Formation of North America is generally similar to Vasalemmoceras, but differs in having a gyroconic growth stage after 1.5 volutions, and in having a lower WER (2.25) (Fig. 14A).

Vasalemmoceras tolerabile Stumbur, 1962

(Fig. 15)

Holotype. Specimen GIT 147-4, herein figured at Fig. 15A, C. Type locality and horizon. Vasalemma, northern Estonia, Vasalemma Formation, Keila Regional Stage.

Diagnosis. As for the genus, by monotypy.

Material. Holotype and twelve additional specimens at the UT and GIT, from localities Rummu and Vasalemma, northern Estonia, Vasalemma. Formation, Keila Regional Stage (see Data Supplement 2). 
Occurrence. Known from the type locality and horizon only.

Description. The holotype, GIT 147-4, is a fragment of the phragmocone and small part of the body chamber. The shell is in total $33 \mathrm{~mm}$ in diametre. The last whorl is c. $13 \mathrm{~mm}$ in width and $16 \mathrm{~mm}$ in height. The shell is gyroconic, coiled in the planispiral plane, the successive whorls touch each other only within the first $360^{\circ}$ degrees. In later growth stages the shell becomes gyroconic. The whorl expansion (WER) is 3 . The ventral side of the shell expands more rapidly (WER 3.3, Fig. 15A). The shell cross-section is compressed in shape (WWI=0.8). The sutures are straight and directly transverse. About eight phragmocone chambers correspond to the respective whorl height ( $\mathrm{rch} 0.12$ ). The siphuncle is ventral, marginal, in contact with the shell wall. The shell surface is sculptured with faint, transverse lines that are ventrally inclined (Fig. 17A).

The remaining material consists of fragments of phragmocones. The largest specimen in the collection (GIT 426-133) has a maximum diametre of c. $31 \mathrm{~mm}$. The last whorl in this specimen is $12 \mathrm{~mm}$ in width and $14 \mathrm{~mm}$ in height. The shell is generally gyroconic, coiled in the planispiral plane $(\mathrm{UWI}=0.2-0.3$, median $=0.25, \mathrm{n}=3)$, the successive whorls touch each other only within the first $360^{\circ}$ degrees. In later growth stages the shell becomes gyroconic. The whorl angle of expansion (WER) is $2.8-3.4$ (median=3.11, $\mathrm{n}=3$ ) and slightly increases during ontogeny. The shell cross-section is compressed in shape (WWI=0.73-0.9, median=0.82, $\mathrm{n}=11$ ). In early ontogenetic stages the shell cross-section is slightly less compressed (WWI is higher and slightly declines with ontogeny, Figs. 8E, 13B, 14B). The sutures are straight or with shallow lateral lobes and directly transverse. Six to ten phragmocone chambers correspond to the respective whorl height ( $\mathrm{rch} 0.1-0.15$, median=0.12, $\mathrm{n}=5$ ). The siphuncle is ventral, marginal, in contact with the shell wall and its position does not change during ontogeny. The siphuncle is narrow, corresponds in diametre to $0.04-0.1$ of the corresponding whorl height. The septal necks are short, suborthochoanitic, the connecting rings are homogenous and slightly expanded (Figs 9C, 15E-F). The shell surface is smooth, with faint, transverse growth-lines that are inclined ventrally (Fig. 15B). The embryonic shell is shown in specimen GIT 426-129a (Fig. 15D). The first whorl, as seen in specimen GIT 426-129a, has nearly straight initial part with a length of 4 $\mathrm{mm}$. In the straight initial part the first two chambers are about one-half millimetre high, the following chambers are $0.25 \mathrm{~mm}$ high. At the position of the 9th and 13th chamber, there is a rapid break in growth direction towards a coiled shell. At the position of c. $360^{\circ}$, the shell starts to uncoil.

Remarks. As for the genus.

Order Barrandeocerida Flower in Flower \& Kummel, 1950 Family, genus and species indet.

Material. Specimen GIT 222-570, from Vasalemma, northern Estonia, Vasalemma Formation, Keila Regional Stage.

Description. The specimen, GIT 222-570, is a fragment of the living chamber with a preserved last septum of the phragmocone. The length of the fragment is $34 \mathrm{~mm}$. The shell is compressed and was contracted at the aperture. The apicalmost part of the shell is $45 \mathrm{~mm}$ dorso-ventrally and $39 \mathrm{~mm}$ laterally in diametre (WWI 0.86). The adoralmost part of the shell is $35 \mathrm{~mm}$ dorsoventrally and $33 \mathrm{~mm}$ laterally in diametre (WWI 0.94). The siphuncle is subcentral in position (rsp 0.3 ) and its diametre is 0.1 of the corresponding shell diametre. The shell was probably smooth. 
Remarks. The specimen represents a barrandeocerid because the shell is large in proportions, cyrtoconic or coiled and the siphuncle is subcentral in position. However, the poor preservation of the specimen does not allow a further determination.

Order Actinocerida Teichert, 1933

Family Gonioceratidae Hyatt, 1884

Genus Hoeloceras Sweet, 1958

Type species. Hoeloceras helgoeyense Sweet, 1958, from the Elnes Formation, late Darriwilianearly Sandbian, Nes-Hamar district, Oslo region, Norway, by original designation.

Diagnosis (after Sweet 1958). Shell orthoconic or curved in shape, depressed (but not flattened), in cross-section. Sutures either straight or bearing dorsal and ventral lobes and lateral saddles. Septal necks short cyrtochoanitic. Connecting rings broadly expanded, recumbent adapically, not recumbent adorally. Endosiphuncular deposits present. Surface smooth or with fine transverse lirae.

Remarks. The genus was considered to be a subjective junior synonym of Lambeoceras Foerste, 1917 by Teichert (1964) but its much smaller size, less depressed conch cross section and less well developed endosiphuncular deposits justify generic distinction

The classification of Hoeloceras within the Gonioceratidae is questionable, because the species is relatively small compared with other gonioceriatids, has no angular flank, and the endosiphuncular deposits are much more reduced than in typical gonioceratids. More details are needed of apical parts of the siphuncle in order to decide if the genus eventually belongs to the Valcouroceratidae of the Oncocerida. Species of Hoeloceras differ from proteoceratids in having strongly expanded siphuncular segments throughout growth and a depressed conch cross section.

Hoeloceras muroni sp. nov.

(Figs 16A, 17D)

Holotype. Specimen TUG 1709-6 (by monotypy).

Type locality and horizon. Rummu Quarry, northern Estonia, Vasalemma Formation, Keila Regional Stage.

Diagnosis. Hoeloceras with a smooth, slightly curved shell, angle of expansion of. c. $11^{\circ}$ and with nearly straight transverse sutures.

Derivation of name. After Mikuláš Muroň (Brno, Czech Republic) who provided MA with technical help and support during the research.

Material. Known from the holotype, only.

Description. The single specimen TUG 1709-6 (Fig. 16A) is part of a phragmocone and living chamber $57 \mathrm{~mm}$ in total height of which $9 \mathrm{~mm}$ is the height of the preserved fragment of the living chamber. The phragmocone is $6 \mathrm{~mm}$ in apical dorso-ventral diametre. The phragmocone is $16 \mathrm{~mm}$ and $20 \mathrm{~mm}$ in most adoral dorso-ventral and lateral diametres, respectively. The shell is slightly curved and depressed in cross-section (the ratio between the lateral and dorsal diametres in the adoral part of the shell is 0.8 ). The angle of expansion dorso-ventrally is $11^{\circ}$. The sutures are straight and directly transverse. Five phragmocone chambers correspond to the respective dorso-ventral shell diametre (rch 0.2 ). Generally, the siphuncle is subcentral in early ontogenetic stages and submarginal in late ontogenetic stages (relative siphuncle position 0.2 ), situated at the convex side of the shell. The siphuncular diametre at the septal foramen is 0.1 of the corresponding dorso-ventral diametre and diametre at the position of the maximum expansion is 0.2 of the corresponding dorso-ventral phragmocone diametre (scr 1.7, rss 0.4 ). The septal necks are cyrtochoanitic, moderately long and recumbent (the recumbent part is thin) (Fig. 17D). The 
connecting rings are thin and homogenous, heart-shaped with the position of the maximum expansion at their adoral half (Fig. 17D). Cameral and intrasiphuncular deposits are not present. The shell is smooth.

Remarks. The genus Hoeloceras was originally described by Sweet (1958) from the Middle Ordovician of Norway. The type species, H. askeri, differs from the Estonian species in being more strongly depressed (ratio between the lateral and dorsal diametres in the adoral part of the shell is 0.6 ), having a lower angle of expansion (less than $10^{\circ}$ ), sutures that form dorsal and ventral lobes, and surface ornamented with longitudinal lirae. H. helgoeyense differs from the Estonian species in having a reticulate ornamentation, a lower angle of expansion $\left(6-7^{\circ}\right.$ at shell diametres about $20 \mathrm{~mm}$ ), and sutures that form dorsal, lateral and ventral lobes.

Family Ormoceratidae Saemann, 1853

Genus Orthonybyoceras Shimizu \& Obata, 1935

Type species. Ormoceras? covingtonense Foerste \& Teichert, 1930, from the Maysvillian Regional Stage, Upper Ordovician, Kentucky, USA, by original designation.

Diagnosis (after Teichert 1964, and Frey 1995). Shell straight, longiconic, circular to slightly depressed in cross-section, moderately to rapidly expanding. Sutures straight, directly transverse or slightly sloping, septa shallow. Phragmocone chambers short. Surface of the shell smooth or sculptured by faint transverse or longitudinal lirae. Siphuncle in position central or slightly subcentral in earliest ontogenetic stages, becomes subventral in later ontogenetic stages. Septal necks short, cyrtochoanitic. Connecting rings thin, homogenous and expanded, recumbent dorsally, not recumbent ventrally to adoral septum. Siphuncular segments with ontogenetic change in shape from short and globular in early growth stages, to globular ovoid, to ovoid elongated in later growth stages. Endosiphuncular deposits annulosiphonate, with central canal and radial canals (dorsal at the middle part of the segments, ventral at the adoral part of the segments), ventral deposits may be more massive, especially on their apical side. Cameral deposits rare, episeptal or hyposeptal, more strongly developed ventrolaterally.

Orthonybyoceras cf. dyeri (Miller, 1875)

(Figs 17A, E, 18B-E, I)

1875 Orthoceras dyeri Miller: 125, fig. 11.

1880 Orthoceras dyeri Miller, Miller: 236, pl. 7, fig. 7.

1995 Orthonybyoceras dyeri (Miller), Frey: 89-90, pl. 18, figs 10-17 (cum syn.).

Diagnosis (after Frey 1995). Small to medium-sized Orthonybyoceras, with angle of expansion of 8.5-10 $10^{\circ}$ with a compressed, subcentral siphuncle, segments one-third to one-fourth the diametre of the shell, short recumbent septal necks, and thin connecting rings dorsally recumbent to adjacent septa.

Material. Ninety-nine specimens, parts and fragments of phragmocones, mostly studied from polished sections, from localities Rummu and Vasalemma, northern Estonia, Vasalemma Formation, Keila Regional Stage (see Data Supplement 2).

Occurrence. Fairview Formation, Grant Lake Limestone Formation, and lower part of the Bull Fork Formation, Edenian to Richmondian of Kentucky, Ohio, and Indiana, USA, and Vasalemma Formation, Keila Regional Stage, northern Estonia, Katian, Late Ordovician.

Description. The material consists of parts of phragmocones ranging from 5-47 $\mathrm{mm}$ diametre. The shells are straight and circular in cross-section. The angle of expansion varies from $4.6^{\circ}$ to 
$11.6^{\circ}$ (median $8.1^{\circ}, \mathrm{n}=16$ ) with no significant ontogenetic trend (Fig. 19A). The sutures are straight and directly transverse. The relative chamber height ( $\mathrm{rch}$ ) varies between 0.1 and 0.3 of the respective shell diametre (median $0.16, \mathrm{n}=26$ ). Narrow septal spacing in fragments with shell diametres $>45 \mathrm{~mm}$ indicates near adult size of some of the fragments. The siphuncular position is subcentral with a general trend of an increasing eccentricity in larger fragments (Fig. 19C). In fragments with shell diametres of $>30 \mathrm{~mm}$ the siphuncular position is more marginal with an rsp of $<0.4$. The cross-section of the siphuncle is circular. Its relative diametre at the septal foramen is 0.04 to 0.12 of the corresponding cross-section diametre (median $0.08, \mathrm{n}=21$ ) and the relative diametre at the position of the maximum expansion is $0.1-0.3$ (median $0.2, \mathrm{n}=22$ ) of the corresponding phragmocone diametre. The shape of the siphuncular segments varies between globular and ovoid with no significant ontogenetic trend (scr 0.7-1.8, median 1.25, $\mathrm{n}=21$; rss 0.25-0.6, median 0.4, $\mathrm{n}=21$ ) (Fig. 19B). The septal necks are orthochoanitic, suborthochoanitic or cyrtochoanitic, short, thin and recumbent in specimens with expanded (globular) connecting rings, and suborthochoanitic in specimens with less expanded (ovoid) connecting rings (Fig. $17 \mathrm{~A}, \mathrm{E})$. The connecting rings in all specimens are thin and homogenous. Cameral deposits were not observed. Annulosiphonate deposits are present and well developed around the septal necks especially in specimens with globular connecting rings (Fig. 17A, E). The shell surface is smooth.

Remarks. The shell morphology of the specimens described above corresponds fully to Orthonybyoceras dyeri Miller, 1875 from the Cincinnatian of the USA as described in Frey (1995). The specimens from the Vasalemma Formation tend to have a more centrally positioned siphuncle than the type material (Fig. 19). However, a quantitative comparison and test, which could prove if the two samples would differ statistically significantly from each other, is impossible with the data published in Frey (1995).

Siphuncular measurements (two measurements) provided by Frey $(1995$, p. 89$)$ indicate that there is a tendency of increase in siphuncular segment expansion, and increase in scr during ontogeny. This is contrary to the genus diagnosis given by Teichert (1964, see above). The material from the Vasalemma Formation does not reveal any statistically significant change in scr during ontogeny. A definite decision on the taxonomic value of this feature and a revision of $O$. dyeri and genus Orthonybyoceras is beyond the scope of this study.

Orthonybyoceras isakari sp. nov. is indistinguishable from Orthonybyoceras cf. dyeri by general shell shape, angle of expansion, siphuncular shape and position, but differs in ornamentation. $O . c f$. dyeri has a smooth shell surface whilst $O$. isakari sp. nov. has a transversally ornamented shell. In both species, specimens with relatively a low angle of expansion occur. It remains an open question, if these specimens represent variants of sexual dimorphs.

Orthonybyoceras isakari sp. nov.

(Figs. 16C, 17B, 18A, G-H)

Holotype. Specimen TUG 1393-19, herein figured at Fig. 18A, G.

Paratype. Specimen TUG 1709-37, herein figured at Fig. 18H.

Type locality and horizon. Vasalemma Quarry, Vasalemma, northern Estonia, Vasalemma Formation, Keila Regional Stage.

Diagnosis. Orthonybyoceras with shell sculptured with faint, straight transverse lirae (3-4 per $\mathrm{mm}$ ), shell orthoconic in shape, with angle of expansion of c. $7.6^{\circ}$, siphuncle central to subcentral with rsp of c. 0.4 , the maximum diametre of the siphuncle c. 0.2 of the shell diametre, connecting rings thin, siphuncular segments expanded with scr of c. 1.3. 
Derivation of name. In honour of Mare Isakar (TUG) who collected together with BK many of the specimens described in this paper.

Material. Holotype, paratype and additional sixty-three specimens, from localities Rummu and Vasalemma, northern Estonia, Vasalemma Formation, Keila Regional Stage (see Data Supplement 2).

Occurence. Vasalemma Formation, Keila Regional Stage.

Description. The holotype, TUG 1393-19, is $82 \mathrm{~mm}$ in height, with the maximum diametre of c. 28 and minimum diametre of $18 \mathrm{~mm}$. The shell is straight and circular in cross-section. The angle of expansion is $9^{\circ}$. The sutures are straight and directly transverse. Nine to ten phragmocone chambers correspond to the respective shell diametre (rch 0.11). The three most adoral phragmocone chambers are shortened (rch 0.04) and followed by a short fragment of the living chamber. The siphuncle is sub-central in position ( $r s p 0.4$ ). The cross-section of the siphuncle is circular, its diametre at the septal foramen is 0.1 of the corresponding cross-section and the siphuncular diametre at the position of the maximum expansion is 0.26 of the corresponding phragmocone diametre (scr 1.6) The septal necks are cyrtochoanitic, moderately long and weakly recumbent (the recumbent part is thin). The connecting rings are thin, homogeneous, strongly expanded within chambers (globular) and recumbent. Endosiphuncular deposits are developed in three most apical chambers as small annuli around the septal necks. The surface of the shell is sculptured by straight, transverse lirae ( 3 per $\mathrm{mm}$ ).

The paratype, TUG 1709-37, is a part of phragmocone and fragment of living chamber 61 $\mathrm{mm}$ in height (of which $29 \mathrm{~mm}$ is the height of the living chamber fragment), with a maximum diametre of 33 and minimum diametre of $27 \mathrm{~mm}$. The shell is straight and circular in crosssection. The angle of expansion is $4.3^{\circ}$. The sutures are straight and directly transverse. Seven to eight phragmocone chambers correspond to the respective shell diametre ( $\mathrm{rch} 0.13$ ). The siphuncle is markedly subcentral ( $\mathrm{rsp} 0.3$ ). The cross-section of the siphuncle is circular. Its relative diametre at the septal foramen is 0.03 , and at the position of the maximum expansion 0.13 (scr 0.9, rss 0.2). The septal necks are cyrtochoanitic, long and recumbent (the recumbent part is thin). The connecting rings are thin, homogeneous, moderately expanded (ovoid) within chambers and recumbent. Endosiphuncular deposits are not present. The surface of the shell is sculptured by straight, transverse lirae ( 3 per $\mathrm{mm}$ ).

The rest of the material consists of parts of phragmocones ranging between 15 and 120 $\mathrm{mm}$ in height $(\mathrm{n}=38), 11 \mathrm{~mm}$ and $36 \mathrm{~mm}$ in minimum diametre (median $23.5 \mathrm{~mm}, \mathrm{n}=36)$ and 14 $\mathrm{mm}$ and $40 \mathrm{~mm}$ in maximum diametre (median $27 \mathrm{~mm}, \mathrm{n}=26$ ). The shell fragments are straight and circular in cross-section. The angle of expansion of all measured fragments ranges between 4 and $11.25^{\circ}$ (median $7.6^{\circ}, \mathrm{n}=13$ ) which decreases with ontogeny (Fig. 19A). The sutures are straight and directly transverse. Six to fourteen (median 10.4, $\mathrm{n}=24$ ) phragmocone chambers correspond to the respective shell diametre ( $\mathrm{rch} 0.07-0.2$, median $0.14, \mathrm{n}=24$ ) with no significant ontogenetic trend. The siphuncle position generally is subcentral, varying between between $0.3-$ 0.5 (median $\mathrm{rsp} 0.4, \mathrm{n}=24$ ) with a strong tendency towards more eccentric positions in later growth stages (Fig. 19C). The cross-section of the siphuncle is circular. Its relative diametre (rsd) at the septal foramen is $0.05-0.2$ (median $0.13, \mathrm{n}=22$ ), and $0.15-0.3$ (median $0.23, \mathrm{n}=18$ ) at the position of the maximum expansion (scr $1-1.7$, median $1.35, \mathrm{n}=15$; rss $0.1-0.58$, median 0.4 , $\mathrm{n}=20$ ). During ontogeny the shape of the siphuncular segments changes from globular to ovoid. Ovoid siphuncular segments occur in fragments with shell cross-sections of $>25 \mathrm{~mm}$ (Fig. 19B). The septal necks are cyrtochoanitic, short, thin and recumbent in fragments with expanded (globular) connecting rings and suborthochoanitic in fragments with less expanded (ovoid) 
connecting rings (Fig. 17B). The rings are thin and homogenous. Cameral deposits were not observed. Annulosiphonate deposits are present and well developed around the septal necks especially in specimens with globular connecting rings (Fig. 17B). The shell is sculptured by straight and transverse, faint to moderate lirae (3 per $\mathrm{mm}$ at shell diametre of $32 \mathrm{~mm}, 4$ per $\mathrm{mm}$ at shell diametre of $20 \mathrm{~mm}$ ) (Fig. 16C).

Remarks. Orthonybyoceras isakari sp. nov. differs from Orthonybyoceras cf. dyeri only in having a transversally annulated shell. The key characters, such as angle of expansion, relative chamber height, siphuncular position, and siphuncular shape, are highly variable within this species, however, sometimes with significant ontogenetic trends (Fig. 19). A cluster analysis of the available fragments reveals that in $O$. isakari, and in $O$. cf. dyeri, few of the fragments differ from the main sample set in having higher angles of expansion of $>4^{\circ}$ (Fig. 19A). However, the sample set does not allow for a further statistical distinction of the specimens of Orthonybyoceras of the Vasalemma Formation other than between the smooth $O$. cf. dyeri and the annulated $O$. isakari sp. nov. It remains an open question, if the low angle of expansion group and the high angle of expansion group that exist within the annulated and smooth species, respectively, eventually represent sexual dimorphs.

\section{Orthonybyoceras moisense sp. nov.}

(Figs 16D, 17C, 18F)

Holotype. Specimen TUG 939-44, herein figured at Fig. 18F.

Paratype. Specimen GIT 222-658, herein figured at Fig. 16D.

Type locality and horizon. Vasalemma, northern Estonia, Vasalemma Formation, Keila Regional Stage.

Diagnosis. Orthonybyoceras sculptured with longitudinal lirae (c. 10 per $\mathrm{mm}$ ); shell orthoconic, with angle of expansion of c. $4^{\circ}$; siphuncle central to subcentral with rsp of c. 0.4 , the maximum diametre of the siphuncle 0.13 of the corresponding shell diametre; connecting rings thin, expanded with an rss of c. 0.4 and scr of c. 0.8 .

Derivation of name. From Vasalemma mõis (Estonian for Vasalemma manor house), refering to the beautiful ornamentation of the shell of this species.

Material. Holotype, paratype and additional five specimens, parts of phragmocones, from localities Vasalemma and Rummu, northern Estonia, Vasalemma Formation, Keila Regional Stage (see Data Supplement 2).

Description. The holotype, TUG 939-44, is a part of phragmocone $34 \mathrm{~mm}$ in height, with a maximum diametre of $27 \mathrm{~mm}$ and minimum diametre of $24 \mathrm{~mm}$. The shell is straight and circular in cross-section. The angle of expansion is $4.2^{\circ}$. The sutures are straight and directly transverse. Five to six phragmocone chambers correspond to the respective shell diametre (rch 0.17). The siphuncle is central. The cross-section of the siphuncle is circular. Its relative diametre at the septal foramen is 0.07 , and 0.14 at the position of the maximum expansion (scr 0.86 , rss 0.47). The septal necks are cyrtochoanitic, thin and recumbent. The connecting rings are thin, homogeneous and moderately expanded (ovoid) within chambers. Small annulosiphonate deposits present (Figs 17C, 18F). Cameral deposits were not observed. The surface of the shell is sculptured by longitudinal lirae (c. 10 per $\mathrm{mm}$ ).

The paratype, GIT 222-658, is a part of phragmocone $35 \mathrm{~mm}$ in height, with a maximum diametre of $34.5 \mathrm{~mm}$. The shell is straight and circular in cross-section. The surface of the shell is sculptured by longitudinal lirae (c. 11 per mm) (Fig. 16D).

The remaining material consists of parts phragmocones ranging between 55 and $80 \mathrm{~mm}$ in height, $12 \mathrm{~mm}$ and $27 \mathrm{~mm}$ in minimum diametre (median $19.5 \mathrm{~mm}, \mathrm{n}=3$ ) and $16 \mathrm{~mm}$ and 34 
$\mathrm{mm}$ in maximum diametre (median $25 \mathrm{~mm}, \mathrm{n}=4)$. The shells are straight and circular in crosssection. The angle of expansion ranges between 3.6 and $5.2^{\circ}$ (median $4.4^{\circ}, n=3$ ) (Fig. 19A). The sutures are straight and directly transverse. Five phragmocone chambers correspond to the respective shell diametre (rch 0.2, specimen TUG 1393-49). The siphuncle in specimen TUG 1393-49 is subcentral ( $r s p 0.37$ at diametre of $28 \mathrm{~mm}$ ) (Fig. 19C). The cross-section of the siphuncle is circular, its relative diametre at the septal foramen is 0.04 , and 0.13 at the position of the maximum expansion (scr 0.78, rss 0.3). The septal necks are cyrtochoanitic, thin and recumbent. The connecting rings are thin, homogeneous and moderately expanded (ovoid) within chambers. Cameral deposits were not observed. Annulosiphonate deposits were not observed. The shell is sculptured by faint, longitudinal lirae (c. 10 per mm).

Remarks. Orthonybyoceras moisense sp. nov. differs from $O$. isakari sp. nov. and $O$. cf. dyeri in having a longitudinally striated ornamentation. $O$. moisense sp. nov. differs from the longitudinally striated Orthonybyoceras crebriseptum (Hall, 1847) from the Upper Utica Shale of New York, USA in having a lower angle of expansion $\left(8.6^{\circ}\right.$ at the shell diametre of $33 \mathrm{~mm}$ in O. crebriseptum, Fig. 19A).

\section{Orthonybyoceras sp.}

Material. Twenty-two specimens, from TUG and GIT, parts of phragmocones, from locality Vasalemma, northern Estonia, Vasalemma Formation, Keila Regional Stage (see Data Supplement 2).

Remarks. The morphology of the above mentioned specimens corresponds fully to the diagnosis of genus Orthonybyoceras, however, the shell wall is not preserved in any of the specimens. Thus, it is not possible to assign any of them at the species level.

\section{Order Orthocerida Kuhn, 1940 \\ Family Proteoceratidae Flower, 1962 \\ Genus Isorthoceras Flower, 1962}

Type species. Orthoceras sociale Hall in Miller, 1877, from the Elgin Member, Maquoketa Formation, latest Katian Stage, Graf, Iowa, USA, by original designation.

Diagnosis (adapted from Flower 1962, Frey 1995, and Kröger 2013b). Orthoconic longicones with subcircular cross-section and subdued ornamentation, smooth or with fine transverse and/or longitudinal lirae, siphuncle subcentral, with barrel-shaped early segments and subcylindrical later segments, septal necks suborthochoanitic-cyrtochoanitic, endosiphuncular annuli growing forward and backward, joining those of adjacent segments to form continuous parietal lining of uniform thickness throughout segments. Mural to episeptal cameral deposits exist.

Remarks. The diagnosis of Isorthoceras given herein is a summary of diagnoses of previuos authors (Flower 1962; Frey 1995; Kröger 2013b, but see Ghavidel-Syooki et al. 2015). The diagnosis follows the original erection of the genus by Flower (1962) which focussed on the characteristics of the siphuncle (barrel shaped during early and nearly tubular during late ontogeny) and in which no explicit description of the sculpture is given. The type species is ornamented with 'fine and very inconspicuous transverse lines which usually do not occur at rhythmic intervals as in typical Geisonoceras' (Foerste 1936, p. 240). Combinations of fine longitudinal and/or transverse ornamentation pattern occur in a number of closely related North American species from the late Ordovician, which are assigned to Isorthoceras by Frey (1995). This is reflected in the diagnosis given herein. The diagnosis of Isorthoceras given in GahvidelSyooki et al. (2015) restricts the genus to species with cancellate ornamentation only, which would be an emendation of the original concept and is rejected herein. 
The earliest occurrence of Isorthoceras, reported so far was Isorthoceras sp. A from the Grange Allen Formation, Burrelian Regional Stage, late Sandbian-early Katian, of the Kildare Inlier, Ireland (Evans 2002). The new species of Isorthoceras from the Vasalemma Formation, described herein are roughly coeval with the Kildare species. The high species diversity of the Vasalemma Isorthoceras suggests that the genus originated before the Keila Regional Stage. 'Arionoceras' lotskirkense Kröger, 2004 from the Middle Ordovician of Sweden, which is probably closely related to and very similar to Isorthoceras in general shell form and septal neck shape, and differs in having a more tubular connecting ring.

Isorthoceras cavi sp. nov.

(Figs 20A, D, 21D, F, 22D)

Holotype. Specimen TUG 1585-41, herein figured at Figs 20A, 21D, 22D.

Paratype. Specimen TUG 1393-22, herein figured at Fig. 20D.

Type locality and horizon. Rummu, northern Estonia, Vasalemma Formation, Keila Regional

Stage.

Diagnosis. Isorthoceras with a straight shell, low to medium angle of expansion $\left(2.5-6^{\circ}\right)$. Shell ornamented with transverse striae (2-4 per $\mathrm{mm}$ ) that form broad, shallow lobe/sinus and are slightly oblique on lateral sides, and with longitudinal lirae ( $8-10$ per $\mathrm{mm})$.

Derivation of name. From Latin cavum, from the cave, referring to the common occurrence in Vasalemma reef pockets.

Material. Holotype, paratype and additional seven specimens, from TUG and GIT, from localities Rummu and Vasalemma, northern Estonia, Vasalemma Formation, Keila Regional Stage (see Data Supplement 2).

Description. The holotype, TUG 1585-41, is a part of phragmocone $60 \mathrm{~mm}$ in height, $12 \mathrm{~mm}$ in maximum diametre, and 11 in minimum diametre. The shell is straight and circular in crosssection. The angle of expansion is $4.4^{\circ}$. Seven to eight phragmocone chambers correspond to the respective shell diametre (rch 0.13). The siphuncle is central in position, its diametre at the septal foramen is 0.05 of the corresponding shell cross-section diametre, and 0.08 of the corresponding shell cross-section diametre at the position of the maximum expansion (scr 0.67 , rss 0.6 ). The septal necks are short, cyrtochoanitic, and recumbent. The connecting rings are thin, homogenous and slightly expanded. Endosiphuncular and cameral deposits were not observed.

The paratype, TUG 1393-22 is a part of phragmocone $79 \mathrm{~mm}$ in height, $14 \mathrm{~mm}$ in maximum diametre, and $6.5 \mathrm{~mm}$ in minimum diametre. The shell is straight and was probably originally circular in cross-section. The angle of expansion is $5.5^{\circ}$. Five to six phragmocone chambers correspond to the respective shell diametre ( $\mathrm{rch} 0.2$ ).

The remaining material consists of parts phragmocones ranging between 10 and $45 \mathrm{~mm}$ in height, $5 \mathrm{~mm}$ and $12 \mathrm{~mm}$ in minimum diametre (median $8.5 \mathrm{~mm}, \mathrm{n}=6$ ) and $7 \mathrm{~mm}$ and $14 \mathrm{~mm}$ in maximum diametre (median $10.5 \mathrm{~mm}, \mathrm{n}=4$ ). The shells are straight and circular in cross-section. The angle of expansion ranges between 2.5 and $5.7^{\circ}$ (median $3.7^{\circ}, \mathrm{n}=6$ ). The sutures are straight and directly transverse. Six to nine phragmocone chambers correspond to the respective shell diametre (rch 0.1-0.15, specimens GIT 222-664 and TUG 1393-45). The siphuncle (Fig. 21F) is central, its relative diametre at the septal foramen is $0.07-0.09(\mathrm{n}=4) 0.04$, and $0.13-0.18(\mathrm{n}=3)$ at the position of the maximum expansion ( $\operatorname{scr} 0.6-0.9, \mathrm{n}=3$; rss $0.4-0.6, \mathrm{n}=2$ ). The septal necks are short, cyrtochoanitic, and recumbent. The connecting rings are thin, homogenous and slightly expanded adorally. Endosiphuncular deposits not present or small, annulosiphonate. Cameral deposits were not observed. 
Remarks. The combination of a coarse lobate transverse and longitudinal ornamentation is unique within known species of Isorthoceras. Isorthoceras cavi differs from all other species of the genus in having a combination of longitudinal and transverse striae, in which the distance between the longitudinal striae is considerably narrower than that of the transverse striae.

Isorthoceras maris sp. nov.

(Figs 20B, 21E, 22E)

Holotype. Specimen TUG 1307-26, herein figured at Fig. 21E, 22E.

Paratype. Specimen TUG 1393-16, herein figured at Fig. 20B.

Type locality and horizon. Vasalemma, northern Estonia, Vasalemma Formation, Keila Regional Stage.

Diagnosis. Isorthoceras ornamented with with sharp transverse lirae (3-4 per $\mathrm{mm}$ ), with two lobes and two saddles across the circumference. Angle of expansion of $\mathrm{c} 3^{\circ}$. Episeptal cameral deposits.

Derivation of name. From Latin, mare, because of the wavy ornamentation.

Material. Holotype and paratype, TUG 1307-26, and TUG 1393-16, from locality Vasalemma, northern Estonia, Vasalemma Formation, Keila Regional Stage.

Description. The holotype, TUG 1307-26 is a part of phragmocone $31 \mathrm{~mm}$ in height, with a diametre of $9-10 \mathrm{~mm}$. The angle of expansion is $3.1^{\circ}$. Three to four phragmocone chambers correspond to the respective shell diametre ( $\mathrm{rch} 0.3$ ). The siphuncle is central in position. Its relative diametre (rsd) at the septal foramen is 0.07 and at the position of the maximum expansion it is 0.1 (scr 0.45 , rss 0.6 ). The septal necks are short, suborthochoanitic, the connecting rings are thin, homogenous and slightly expanded (Fig. 22E). Episeptal cameral deposits occur. Endosiphuncular deposits are not present.

The paratype TUG 1393-16, is a part of phragmocone $40 \mathrm{~mm}$ in height, with a maximum diametre of $9 \mathrm{~mm}$ and a minimum diametre of $7 \mathrm{~mm}$. The shell is straight and circular in crosssection. The angle of expansion is $2.4^{\circ}$. The siphuncle is central in position. The relative diametre of the siphuncle (rsd) at the septal foramen is 0.1 .

Remarks. Isorthoceras maris sp. nov. is similar to Isorthoceras curvilineatum Kröger, 2013b with respect to its wavy transverse ornamentation. The striae in I. curvilineatum are, however, more closely spaced (c. 10 per $\mathrm{mm}$ ).

\section{Isorthoceras padisense sp. nov.}

(Figs 20C, 21G, 22F)

Holotype. Specimen TUG 1585-18b, herein figured at Fig. 20C.

Paratype. Specimen TUG 1709-5, herein figured at Fig. 21G, 22F.

Type locality and horizon. Rummu near Vasalemma, northern Estonia, Vasalemma Formation, Keila Regional Stage.

Diagnosis. Isorthoceras with a straight shell, moderate angle of expansion $\left(\mathrm{c.} 6^{\circ}\right)$, ornamented with faint longitudinal lirae (10-12 per mm).

Derivation of name. From Padise, a village near the type locality.

Material. Holotype and an additional specimen TUG 1709-5, from the type locality and horizon.

Description. The holotype, TUG 1585-18b, is a part of phragmocone $50 \mathrm{~mm}$ in height, with maximum diametre $15 \mathrm{~mm}$, and minimum diametre $10 \mathrm{~mm}$. The shell is straight and circular in cross-section. The angle of expansion is $6^{\circ}$. Five to six phragmocone chambers correspond to the respective shell diametre ( $\mathrm{rch} 0.2)$. The siphuncle is in position in between the longitudinal axis 
of the shell and the shell wall (rsp 0.3). The cross-section of the siphuncle is circular, its diametre at the septal foramen is 0.11 of the corresponding shell cross-section.

Specimen TUG 1709-5 is a part of phragmocone $19 \mathrm{~mm}$ in height, with maximum diametre $14 \mathrm{~mm}$, and minimum diametre $13 \mathrm{~mm}$. The shell is straight and circular in crosssection. The angle of expansion is $6^{\circ}$. Four to five phragmocone chambers correspond to the respective shell diametre ( $r c h 0.2$ ). Diametre of the siphuncle at the position of the septal foramen is 0.07 and diametre at the position of the maximum expansion is 0.1 of the corresponding phragmocone diametre (scr 0.4, rss 0.7). Septal necks are short, cyrtochoanitic, recumbent. Connecting rings are thin, homogenous and sligtly expanded (Fig. 22F). The last phragmocone chamber is shortened, indicating an adult size of the specimen.

Remarks. Isorthoceras padisense sp. nov. is one of a number of similar exclusively longitudinally ornamented species of genus Isorthoceras. Isorthoceras albersi (Miller \& Faber, 1894), which is a common species in the early Katian, Lexington Limestone in the Cincinnati arch region (Frey 1995) differs in having a higher angle of expansion (7-8 ${ }^{\circ}$ ). Isorthoceras hudsonicum (Ruedemann, 1912) possesses a slightly curved shell. The ornamentation in Isorthoceras strigatum (Hall, 1847) has a wider spacing with 1-2 striae per mm.

Isorthoceras vexilli $\mathrm{sp}$. nov.

(Figs 20G, 21C, H, 22C)

Holotype. Specimen TUG 939-11, herein figured at Figs 20G, 21H.

Paratype. Specimen TUG 939-33, herein figured at Fig. 21C, 22C.

Type locality and horizon. Vasalemma, northern Estonia, Vasalemma Formation, Keila Regional Stage.

Diagnosis. Isorthoceras with moderate angle of expansion (c. $4.3^{\circ}$ ). Sculptured with slightly oblique faint, rounded, directly transverse lirae (two per mm; sloping at the angle of 5-10 ${ }^{\circ}$ ).

Derivation of name. From Latin, vexillum, a banner.

Material. Holotype, paratype and an additional specimen, TUG 939-11, TUG 939-33, TUG 1585-18c, from the type locality and horizon (see Data Supplement 2).

Description. The holotype, TUG 939-11, is a part of phragmocone and the living chamber. The specimen is $67 \mathrm{~mm}$ in total height, with $20 \mathrm{~mm}$ maximum diametre, and $18 \mathrm{~mm}$ minimum diametre. The preserved part of the living chamber is $29 \mathrm{~mm}$ long and its diametre seems to decline slightly adorally, to form a shallow constriction in its adoral-most part. The shell is straight and was probably circular in cross-section. The angle of expansion is $4.3^{\circ}$. Four to five phragmocone chambers correspond to the respective shell diametre ( $\mathrm{rch} 0.21)$. The latest phragmocone chambers are shortened, the last phragmocone chamber has rch of 0.05 . The siphuncle is almost central adapically and clearly subcentral adorally (relative siphuncle position 0.3). The siphuncular diametre is c. 0.1 respective to the shell diametre (scr 0.6, rss 0.9). The septal necks are short, suborthochoanitic. The connecting rings are thin, homogenous and slightly expanded in front of the adoral septal foramen.

The paratype, TUG 939-33, is a polished part of a phragmocone with $27 \mathrm{~mm}$ in total height, maximum diametre of $14 \mathrm{~mm}$, and minimum diametre $13 \mathrm{~mm}$. The shell is straight and was probably circular in cross-section. The angle of expansion is $3.6^{\circ}$. Four to eight phragmocone chambers correspond to the respective shell diametres ( $\mathrm{rch} 0.2$ ). The changes in the chamber height are irregular during ontogeny. The specimen is sectioned laterally but the dorso-ventral side of the shell shows the subcentral position of the siphuncle (rsp 0.37). The diametre of the siphuncle, as studied from the available lateral section of the shell, is 0.06 of the corresponding cross-section at the septal foramen and 0.13 at the position of the maximum 
expansion (scr 0.64, rss 0.5). The septal necks are short, and suborthochoanitic. The connecting rings are thin, homogenous and expanded (Fig. 22C).

Specimen TUG 1585-18 (C) is a part of phragmocone with $23 \mathrm{~mm}$ in height, $11 \mathrm{~mm}$ maximum diametre, and $9 \mathrm{~mm}$ minimum diametre. The shell is straight and circular in crosssection. The angle of expansion is $5^{\circ}$.

Remarks. Isorthoceras vexilli differs from other transversely striated species of the genus: Isorthoceras sp. A (Evans, 2002) differs in having a denser striation (6 per $\mathrm{mm})$, Isorthoceras? sp. B (Evans, 2002) differs in having a higher angle of expansion $\left(12^{\circ}\right)$, Orthoceras aff. elongatocinctum (Portlock, 1843), differs in having adorally imbricated and more densely spaced striae (up to 7 per $\mathrm{mm}$ ), Isorthoceras heroyense (Strand, 1934) differs in having striae that slope with a lower angle $\left(<5^{\circ}\right)$ and in having a wider siphuncle (more than 0.15 of the corresponding shell diametre), and Isorthoceras heintzi (Strand, 1934), Isorthoceras junceum (Hall, 1847), and Isorthoceras bisignatum (Barrande, 1877) differ in having directly transverse striae.

Family Orthoceratidae McCoy, 1844

Genus Pleurorthoceras Flower, 1962

Type species. Orthoceras clarksvillense Foerste, 1924, Waynesville Formation, Richmondian Regional Stage, Upper Ordovician, Ohio, USA, by subsequent designation (Flower 1962).

Diagnosis (after Frey 1995). Slender, orthonic, longiconic orthoceratids with circular shell crosssection, straight and transverse sutures and chamber heights from one-third to one-half the diametre of the shell, body chamber long, tubular, shell surface smooth, siphuncle slightly subcentral in position, narrow, almost tubular, septal necks short, suborthochoanitic, connecting rings thin, homogenous, only slightly expanded, endosiphuncular deposits unknown, cameral deposits initially mural, during ontogeny mural-episeptal and thickened ventrally.

Pleurorthoceras organi sp. nov.

(Figs 20E-F, 21I, 22B)

Holotype. Specimen TUG 1307-27, herein figured at Fig. 20F.

Paratype. Specimen TUG 939-84B, herein figured at Figs 21I, $22 B$.

Type locality and horizon. Vasalemma, northern Estonia, Vasalemma Formation, Keila Regional Stage.

Diagnosis. Pleurorthoceras with a smooth shell, angle of expansion $<4^{\circ}$ and a relatively wide chamber spacing with rch $0.3-0.4$.

Derivation of name. From Latin, organum, from the organ, refers to its resemblance with an organ pipe.

Material. Holotype and additional four specimens, held at the UT and GIT, from locality Vasalemma (see Data Supplement 2).

Description. The holotype, TUG 1307-27, is a part of phragmocone $92 \mathrm{~mm}$ in height, with maximum diametre $10 \mathrm{~mm}$, and minimum diametre $8 \mathrm{~mm}$. The shell is straight and circular in cross-section. The angle of expansion is $2.5^{\circ}$. The siphuncle is central to slightly subcentral in position. The diametre of the siphuncle at the septal foramen is 0.1 of the corresponding shell cross-section. The shell surface is smooth. Endosiphuncular deposits are not present.

The paratype, TUG 939-84b, is a cut and polished section of a phragmocone $21 \mathrm{~mm}$ in height, $7 \mathrm{~mm}$ in maximum and $6 \mathrm{~mm}$ in minimum diametre. The angle of expansion is $2.6^{\circ}$. The shell has a circular cross-section and a central, narrow siphuncle with the relative diametre of 0.1 at the position of the maximum expansion ( $\mathrm{scr} 0.35$ ). The connecting rings are slightly expanded 
(Fig. 22B). Endosiphuncular deposits are not present. Cameral deposits are mural and episeptal. Three to four phragmocone chambers correspond to phragmocone diametre (rch 0.4). Shell surface smooth.

Specimens TUG 939-84a and TUG 939-84c are two cut and polished sections of phragmocones supposedly belonging two individuals. They are 23 and $10 \mathrm{~mm}$ in height, with the maximum diametre of 9 and $8.5 \mathrm{~mm}$ and minimum diametre of $8 \mathrm{~mm}$. The angle of expansion is 3.3 and $2.6^{\circ}$, respectively. The shells have a circular cross-section and a central, narrow siphuncle. Diametre at the position of the maximum expansion of the siphuncle in specimen TUG 939-84a is 0.09 of the phragmocone diametre (scr 0.42 ). The connecting rings are slightly expanded at their adoral and adapical parts. Endosiphuncular deposits are not present. Cameral deposits are mural and episeptal. Three to four phragmocone chambers correspond to phragmocone diametre (rch 0.35 and 0.3 , respectively). Shell surface smooth.

Specimen GIT 222-536-2 (Fig. 20E) is a part of a phragmocone $45 \mathrm{~mm}$ in height, $5 \mathrm{~mm}$ in minimum diametre and $7 \mathrm{~mm}$ in maximum diametre. The shell is straight and circular in cross-section. The angle of expansion is $2.6^{\circ}$. The siphuncle is narrow and central in position. cross-section of the siphuncle is circular. Shell surface is smooth.

Remarks. Pleurorthoceras organi sp. nov. differs from Pleurorthoceras clarksvillense in having slightly shorter phragmocone chambers (rch $0.3-0.5$ vs. rch $0.3-0.4$ ), slightly lower angle of expansion (4-5 $5^{\circ}$ vs. $\left.2.5-3.3^{\circ}\right)$ and in being generally larger in proportions. Pleurorthoceras chinense Chen, 1987 differs in much smaller proportions of the shell, in having a wider siphuncle (rsd 0.16) and heigher phragmocone chambers (rch 0.7). Pleurorthoceras selkirkense (Whiteaves, 1891) differs in having an eliptical-shaped cross-section and sculpture (annulations, raised ridges) and a marginal siphuncle.

\section{Family Geisonoceratidae Zhuravleva, 1959}

Genus Ordogeisonoceras Frey, 1995

Type species. Orthoceras amplicameratum Hall, 1847, from the Trenton Formation, latest Katian, Middleville, New York, USA, by original designation.

Diagnosis (adapted after Frey 1995). Shell is straight, longiconic, circular in cross-section. Sutures are straight, transverse. Phragmocone chambers are as high as one-half the diametre of the shell. Living chamber is long and tubular. Surface ornamented with fine longitudinal or transverse striae. Siphuncle situated close to the dorsal margin later in ontogeny, more central earlier in ontogeny. Siphuncular segments are elongate, depressed. Septal necks are suborthochoanitic. The connecting rings are thin, homogenous, and slightly expanded. Small annulosiphonate deposits are developed adapically. Cameral deposits are developed adapically. Hyposeptal and episeptal cameral deposits are developed ventrally and episeptal dorsally.

Remarks. The diagnosis is compiled from the diagnosis given in Frey (1995: P39) and from the description of the type species in Frey (1995: P40). In Frey's (1995) diagnosis of Ordogeisonoceras, it is not explicitly mentioned that the siphuncle position shifts during ontogeny from more central towards the shell margin. However, this siphuncular shift is a character of the type species as described in Frey (1995: P40) and we evaluate this character as important for the genus diagnosis.

\section{Ordogeisonoceras tartuensis sp. nov.}

(Figs 20H, 21B, 22A)

Holotype. Specimen TUG 939-10, herein figured at Fig. 21B, 22A. 
Type locality and horizon. Vasalemma, northern Estonia, Vasalemma Formation, Keila Regional Stage.

Diagnosis. Siphuncle central to slightly subcentral in position, 0.14 to 0.17 in diametre (relative to shell diametre), septal necks suborthochoanitic, shell sculptured with fine straight and transverse lirae (8-12 per $\mathrm{mm}$ ).

Derivation of name. From the city of Tartu, Estonia, where the holotype specimen is held. Material. The holotype and additional six specimens (held at TUG and GIT, from locality Vasalemma (see Data Supplement 2).

Description. The holotype, specimen TUG 939-10, is a part of a sectioned and polished phragmocone $36 \mathrm{~mm}$ in height, $22 \mathrm{~mm}$ in minimum and $23 \mathrm{~mm}$ in maximum diametre. The shell is straight and circular in cross-section. The sutures are straight and directly transverse. Two to

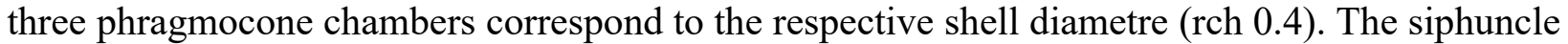
is slightly subcentral ( $\mathrm{rsp} 0.46$ ). Its diametre at the septal foramen is 0.1 and maximum diametre of the connecting rings is 0.14 of the phragmocone diametre (scr 0.4, rss 0.7 ). The septal necks are straight, orthochoanitic. The connecting rings are thin, homogenous and expanded adorally. Small annulosiphonate deposits were observed (Fig. 22A). The cameral deposits are mural.

Specimens included under TUG 939-1065 are five parts of cut and polished phragmocones ranging between 33 and $56 \mathrm{~mm}$ in height, $17 \mathrm{~mm}$ and $24 \mathrm{~mm}$ in minimum diametre (median 20.5, $\mathrm{n}=5$ ) and $18 \mathrm{~mm}$ and $26 \mathrm{~mm}$ in maximum diametre (median 22, $\mathrm{n}=5$ ). The shells are straight and circular in cross-section. The angle of expansion ranges between 3 and $4.3^{\circ}(\mathrm{n}=3)$. The sutures are straight and directly transverse. Two to four phragmocone chambers correspond to the respective shell diametre ( $\mathrm{rch} 0.25-0.4$, median $0.34, \mathrm{n}=5)$. The siphuncle is central or slightly subcentral. The siphuncular diametre at the septal foramen is $0.05-0.1$ (median $0.09, \mathrm{n}=4$ ) and maximum diametre of the connecting rings is 0.1 and 0.17 (median $0.13, \mathrm{n}=4$ ) of the phragmocone diametre ( $\operatorname{scr} 0.3-0.44$, median $0.4, \mathrm{n}=5$; rss $0.4-0.8$, median $0.6, \mathrm{n}=5$ ). The septal necks are straight, orthochoanitic or slightly inclined. The connecting rings are thin, homogenous and expanded adorally. The annulosiphonate deposits, and mural and/or episeptal cameral deposits are small. The shell is covered by faint, straight and transverse lirae (8-12 per mm, corresponding diametre $26 \mathrm{~mm}$ ) (Fig. 20H).

Specimen GIT 222-667 is a part of a sectioned and polished phragmocone $53 \mathrm{~mm}$ in height, $15 \mathrm{~mm}$ in minimum and $17 \mathrm{~mm}$ in maximum diametre. The shell is straight and circular in cross-section. The angle of expansion is $2^{\circ}$. The sutures are straight and directly transverse. Three phragmocone chambers correspond to the respective shell diametre (rch 0.34). The siphuncle is almost central. Its diametre at the septal foramen is 0.06 and maximum diametre of the connecting rings is 0.1 of the phragmocone diametre (scr 0.3, rss 0.6). Septal necks are straight, orthochoanitic. Connecting rings are thin, homogenous and expanded adorally. The annulosiphonate deposits are small, and cameral deposits (episeptal and mural) occur.

Remarks. Ordogeisonoceras tartuensis sp. nov. differs from Ordogeisonoceras amplicameratum (Hall, 1847) in having a transversely lirated shell, it differs from Ordogeisonoceras foerstei (Strand, 1934) in having a more narrowly spaced and directly transverse sculpture. The siphuncular positions of $O$. amplicameratum and $O$. foerstei are more eccentric than that of $O$.tartuensis sp. nov., but in all three species the position shifts during growth along the dorsoventral axis. We consider this latter character as important for the genus determination and evaluate differences in the actual amplitude as species characteristics.

Ordogeisonoceras? sp.

(Figs 20I, 21A) 
Material. Two specimens (TUG 939-8 and TUG 939-9a, from locality Vasalemma, northern Estonia, Vasalemma Formation, Keila Regional Stage.

Description. Specimen TUG 939-8 (Fig. 20I) is a part of a sectioned and polished phragmocone $35 \mathrm{~mm}$ in height, $25 \mathrm{~mm}$ in minimum and $29 \mathrm{~mm}$ in maximum diametre. The shell is straight and circular in cross-section. The sutures are straight and directly transverse. Three phragmocone chambers correspond to the respective shell diametre (rch 0.33). The siphuncle is slightly subcentral ( $\mathrm{rsp}$ 0.44). Its diametre is c. 0.1 of the corresponding phragmocone diametre (scr 0.35 , rss 0.97). Septal necks are orthochoanitic, completely straight and short. Connecting rings are thin, homogenous and tubular. Cameral and endosiphuncular deposits are not present. Shell is sculptured by fine straight and transverse lirae (6 per $\mathrm{mm}$ at the corresponding shell diametre of $28 \mathrm{~mm})$.

TUG 939-9a (Fig. 21A) is a part of a sectioned and polished phragmocone is $46 \mathrm{~mm}$ in height, $30 \mathrm{~mm}$ in minimum and $33 \mathrm{~mm}$ in maximum diametre. The shell is straight and circular in cross-section. The shell is sculptured with straight and directly transverse lirae. The sutures are straight and directly transverse. Three phragmocone chambers correspond to the respective shell diametre (rch 0.3). The siphuncle is very slightly subcentral (relative siphuncle position 0.44). Its diametre is c. 0.1 of the phragmocone diametre (scr 0.38, rss 0.9). Septal necks are orthochoanitic, completely straight and short. Connecting rings are thin, homogenous and tubular (Figs 21A). Cameral and endosiphuncular deposits are not present.

Remarks. The specimens described above, differ from Ordogeisonoceras tartuensis in having completely tubular connecting rings and more widely spaced lirae (6 per $\mathrm{mm}$ ). The specimens are relatively large parts of phragmocones, which are in general shell morphology very similar to the previous species. The differences in siphuncular shape and sculpture density in comparing to the previous species may represent an ontogenetic trend rather than being taxonomically significant. Based on the limited material and the lack endosiphuncular or cameral deposits no species designation is possible. The specimens do not belong to Orthoceras Brugiére, 1789, because they lack the characteristic fine longitudinal ornament of this genus.

Order Discosorida Flower in Flower \& Kummel, 1950

Family Westonoceratidae Teichert, 1933

Genus Hemibeloitoceras Balashov, 1962

Type species. Hemibeloitoceras ellipsoidale Balashov, 1962, from the Krivolutsk Regional Stage, Middle Ordovician, Siberian Platform, Russian Federation, by original designation. Emended diagnosis. Shell small longiconic, straight to slightly curved, compressed in crosssection (ratio lateral/dorsal diametres 0.6-0.8). Shell smooth with shallow, irregularly spaced undulations and fine growth lines. Sutures straight and directly transverse or with shallow saddle on the venter and dorsum. Phragmocone chambers shallow (more than 10 per distance similar to corresponding shell cross-section). Siphuncle marginal, almost in contact with shell wall at the convex side of the shell curvature; with a diametre of $0.13-0.18$ of the corresponding shell crosssection. Siphuncular segments strongly expanded, globular. Septal necks short, cyrtochoanitic. Mural cameral deposits and endosiphuncular deposits present.

Remarks. The diagnosis largely follows the original description of Balashov (1962) and is emended herein, in order to include species with a higher angle of expansion and with fine transverse ornament of undulations and growth-lines (see Fig. 23C). In the original diagnosis the angle of expansion was based on the type species only (angle of expansion $8^{\circ}$ in H. ellipsoidale 
Balashov, 1962) despite the apical angle of the second (sub-) species, originally included in this genus, H. ellipsoidale nujense Balashov, 1962 is unknown. Herein the original narrow concept of the genus is widened in order to include the species of the Vasalemma Formation, which differ from the type species only in having a fine transverse ornamentation and in having a slightly wider angle of expansion ( $15^{\circ}$ in Hemibeloitoceras molis sp. nov).

\section{Hemibeloitoceras arduum sp. nov.}

(Figs 23A-B, D-F)

Holotype. Specimen TUG 1612-12, herein figured at Fig. 23B, E. Type locality and horizon. Rummu, near Vasalemma, northern Estonia, Vasalemma Formation, Keila Regional Stage.

Diagnosis. Orthoconic Hemibeloitoceras with compressed shell cross section (ratio of lateral/dorsal diametres c. 0.74). Angle of expansion $10^{\circ}$ or less. Shell smooth with shallow, irregularly spaced undulations and fine growth lines. Sutures straight and directly transverse; more than 10 phragmocone chambers relative to the shell diametre. Siphuncular diametre c. 0.2 of the corresponding shell cross section. Siphuncle marginal in position, septal necks short, cyrtochoanitic, connecting rings strongly expanded, globular. Cameral deposits mural, endosiphuncular deposits not developed.

Derivation of name. From Latin, arduum, towering, because of its tower-like shell form. Material. Holotype and additional two specimens (TUG 1612-13 and TUG 1585-49), held at the UT, from localities Rummu and Vasalemma, northern Estonia, Vasalemma. Formation, Keila Regional Stage (see Data Supplement 2).

Occurence. Northern Estonia, Upper Ordovician, lower Katian, Keila Regional Stage. Description. The holotype, TUG 1612-12, is part of a phragmocone $23 \mathrm{~mm}$ in height, with diametres 22-26 mm (dorso-ventrally), 18-21 mm (laterally), with elliptically compressed shell cross section, with ratio of lateral/dorsal diametres c. 0.8 . The angle of expansion is $9.7^{\circ}$ dorsoventrally and $8^{\circ}$ laterally. The sutures are straight and directly transverse. Eighteen phragmocone chambers correspond to the respective shell diametre ( $\mathrm{rch}$ is 0.06 at shell diametre of $23 \mathrm{~mm}$ ). The siphuncle is marginal, almost in contact with the shell wall. The siphuncular diametre at the position of the maximum expansion is 0.2 and diametre at the septal foramen is 0.06 of the corresponding shell cross-section (scr 4, rss 0.3). The septal necks are short cyrtochoanitic. The connecting rings are homogenous and expand strongly within the chambers (Figs 4B, 23E). Shell smooth with shallow, irregularly spaced undulations and fine growth lines.

Specimen TUG 1612-13 (Fig. 23A, F) is part of a phragmocone $31 \mathrm{~mm}$ in height with adoral diametre $17 \mathrm{~mm}$ (lateral), and apical diametres $18 \mathrm{~mm}$ (dorso-ventral), $14 \mathrm{~mm}$ (lateral), with compressed shell cross section (ratio of lateral/dorsal diametres apically 0.78 ). The sutures are straight and directly transverse. Sixteen phragmocone chambers correspond to the respective shell diametre (rch 0.06 at shell diametre of $17 \mathrm{~mm}$ ). The siphuncle is marginal, almost in contact with the shell wall. The siphuncular diametre at the position of the maximum expansion is 0.2 and diametre at the septal foramen is 0.06 of the corresponding shell cross section (scr 3 , rss 0.3 ). The septal necks are short and cyrtochoanitic. The connecting rings are similar to connecting rings of other westonoceratids, homogeneous and expand strongly within the chambers (Fig. 23. Shell smooth with shallow, irregularly spaced undulations and fine growth lines (Fig. 23A). The shell is slightly constricted at the central part of the specimen (Fig. 23A).

Specimen TUG 1585-49 (Fig. 23D) is part of a phragmocone $50 \mathrm{~mm}$ in height, with adoral diametre $15 \mathrm{~mm}$ (dorso-ventral), and apical diametres $21 \mathrm{~mm}$ (dorso-ventral), $14 \mathrm{~mm}$ (lateral), with compressed shell cross section (ratio of lateral/dorsal diametres apically 0.64 ). 
The dorso-ventral angle of expansion is $7^{\circ}$. Shell smooth with shallow, irregularly spaced undulations and fine growth lines (Fig. 23D).

Remarks. Hemibeloitoceras arduum sp. nov. differs from the type species in having the shell sculptured by irregularly spaced undulations and fine growth lines and from Hemibeloitoceras molis sp. nov. in having a considerably lower angle of expansion (less than $10^{\circ}$ against c. $15^{\circ}$ in $H$. molis sp. nov.).

\section{Hemibeloitoceras molis sp. nov.}

(Fig. 23G)

Holotype. Specimen GIT 426-164, herein figured at Fig. 23G.

Type locality and horizon. Vasalemma, northern Estonia, Vasalemma Formation, Keila Regional Stage, lower Katian, Upper Ordovician.

Diagnosis. Hemibeloitoceras with straight shell, nearly circular shell in cross section in early growth stages and slightly compressed (ratio of lateral/dorsal diametres c. $0.7-0.8$ ) in later growth stages. Angle of expansion $>15^{\circ}$. Shell smooth with shallow, irregularly spaced undulations and fine growth lines. Sutures straight and directly transverse, with more than ten phragmocone chambers relative to the shell diametre (rch c. 0.1). Siphuncular diametre c. 0.17 of the corresponding shell cross section. Siphuncle marginal in position.

Derivation of name. From Latin, molis, massive, because of its massive shell form. Material. Holotype, paratype and additional six specimens, from localities Rummu and Vasalemma (see Data Supplement 2).

Description. The holotype, specimen GIT 426-166, is a phragmocone measuring $34.5 \mathrm{~mm}$ in total height, with dorso-ventral diametre $23 \mathrm{~mm}$ and lateral diametre $15 \mathrm{~mm}$, and with compressed shell cross section (ratio lateral/dorsoventral diametres: 0.65 adorally, 0.9 adapically). The dorso-ventral angle of expansion is $21.4^{\circ}$. The siphuncle is marginal, almost in contact with the shell wall (rsp 0.13). The siphuncle is preserved with connecting rings, the siphuncular diametre at the septal foramen is 0.17 of the corresponding shell cross section. Shell surface smooth.

Specimen TUG 1307-2a is a fragmented phragmocone measuring $34 \mathrm{~mm}$ in total height, with dorso-ventral diametre 12-24 mm, and with compressed shell cross section (ratio lateral/dorsoventral diametres: 0.66 adorally, 0.83 adapically). The dorso-ventral angle of expansion is $26^{\circ}$. Eleven phragmocone chambers correspond to the respective shell diametre (rch 0.09 at shell diametre of $12 \mathrm{~mm}$ ). The sutures are straight and directly transverse. The siphuncle is marginal, almost in contact with the shell wall. The siphuncular diametre at the septal foramen is 0.17 of the corresponding shell cross section. Shell smooth with shallow, irregularly spaced undulations and fine growth lines.

Specimen TUG 1585-32 is part of a phragmocone measuring $28 \mathrm{~mm}$ in height, with dorso-ventral diametre 19-25 mm, and lateral diametre 19-20 mm. Ratio of lateral and dorsal diametres at the adoral part of the shell is 0.8 . The dorso-ventral angle of expansion is $17^{\circ}$. Eighteen phragmocone chambers correspond to the respective shell diametre (rch 0.06 at shell diametre of $25 \mathrm{~mm}$ ). The sutures are straight and directly transverse. Maximum siphuncular diametre is 0.14 of the corresponding phragmocone diametre.

Remaining two specimens (GIT 222-683, GIT 426-164) are parts of phragmocones measuring up to $28.5 \mathrm{~mm}$ in height, with respective maximum diametres of $22.6 \mathrm{~mm}$ and $28 \mathrm{~mm}$ (dorsoventral) and $16 \mathrm{~mm}$ and $18 \mathrm{~mm}$ (lateral). The ratio of lateral/dorso-ventral diametres is adorally 0.7 and 0.64 . The angle of expansion in specimen GIT 426-164 is $15.5^{\circ}$ laterally. Ten phragmocone chambers correspond to the respective shell diametre ( $\mathrm{rch} 0.1$ at shell diametre of 
$16 \mathrm{~mm}$ ) in specimen GIT 426-164. The sutures are straight and directly transverse. The siphuncle is marginal in position, with a diametre of 0.19 of the corresponding shell cross section (specimen GIT 222-683).

Remarks. The species differs from the type species and from Hemibeloitoceras arduum sp. nov. in its greater angle of expansion (more than $15^{\circ}$ ).

Order Oncocerida Flower in Flower \& Kummel, 1950

Family Oncoceratidae Hyatt, 1884

Genus Beloitoceras Foerste, 1924

Type species. Oncoceras pandion Hall, 1861, from the Black River Formation, Sandbian, Upper Ordovician, by original designation.

Diagnosis (after Frey 1995). Shell strongly curved and breviconic, circular to compressed in cross-section. Inflation of shell occurs in the adoral part of the phragmocone. Sutures straight and transverse, adapically, sloping with ontogeny to the concave side of the shell curvature.

Phragmocone chambers short (five to eight relative to shell diametre), increasing with ontogeny. Living chamber short, compressed. Muscle-scars ventromyarian. Surface smooth or with fine, raised transverse lirae. Siphuncle on the convex side of the shell curvature. Siphuncular segments subtubular, adapically, expanded and elongate ovate, adorally. Septal necks short, adapically, suborthochoanitic, more recurved and cyrtochoanitic with ontogeny. Connecting rings thin, homogenous. Endosiphuncular deposits not present. Cameral deposits may be present.

\section{Beloitoceras cautis sp. nov.}

(Fig. 4A, 24A-B, D)

Holotype. Specimen TUG 939-54 (by monotypy).

Type locality and horizon. Vasalemma, northern Estonia, Vasalemma Formation, Keila Regional Stage.

Diagnosis. Beloitoceras of a greater adult shell size with adult shell cross section of c. $36 \mathrm{~mm}$, with nearly circular shell cross section, with large, broadly expanded siphuncle, sculptured by straight and transverse rounded lirae (1 per $\mathrm{mm}$ at shell diametre $30 \mathrm{~mm}$ ), slight inflation at the concave side of the shell in the middle position between the phragmocone and living chamber.

Derivation of name. From Latin, cautis, reef.

Material. Known from the holotype, only.

Description. The holotype, specimen TUG 939-54, is part of a phragmocone and living chamber $59 \mathrm{~mm}$ in height, of which $25 \mathrm{~mm}$ is the height of the phragmocone. The living chamber is 34 $\mathrm{mm}$ in height and is nearly complete. Maximum diametre at adapical third is $35 \mathrm{~mm}$ dorsoventrally and $33.5 \mathrm{~mm}$ laterally (ratio 0.96). Maximum diametre at about the middle part of the living chamber is $36 \mathrm{~mm}$ dorso-ventrally. Maximum diametre at adoral third is $34.5 \mathrm{~mm}$ dorsoventrally. The living chamber is compressed. The aperture margin is not fully preserved but it is visible that the aperture was laterally restricted to create at least two lobes. Shell sculptured by coarse rounded transverse lirae (1 per $\mathrm{mm}$ at the diametre of $30 \mathrm{~mm}$ ).

The angle of expansion of the phragmocone at the lateral side is $22^{\circ}$. The sutures are straight and directly transverse. Seven phragmocone chambers correspond to the respective shell diametre (rch 0.14). The siphuncle is close to the shell margin, but not marginal, at the convex side of shell curvature. The siphuncular diametre at the septal foramen is 0.8 of the corresponding shell cross-section, and 0.15 at the position of the maximum ( $\operatorname{scr} 1.5$, rss 0.5$)$. The septal necks are short suborthochoanitic to cyrtochoanitic. The connecting rings are homogeneous and expand strongly within the chambers (globular in shape) (Figs 24D, 4A). Endosiphuncular or cameral 
deposits are not present. The surface of the shell is sculptured with coarse, straight and transverse lirae (1-2 per $\mathrm{mm}$ at the diametre of $30 \mathrm{~mm}$ ) (Fig. 24A, B).

Remarks. The otherwise similar Beloitoceras janesvillense Foerste, 1933 from the Platteville Formation, Sandbian Stage, Wisconsin, USA, differs in being more compressed (ratio of lateral and dorsal diametres of the phragmocone is 0.72-0.79). Beloitoceras stoermeri Sweet, 1958 from the Arnestad Formation, Sandbian Stage, Norway differs in having a larger adult size (maximum shell cross section c. $60 \mathrm{~mm}$ ) and only slightly expanded connecting rings.

\section{Beloitoceras sp. indet}

Type locality and horizon. Vasalemma, northern Estonia, Vasalemma Formation, Keila Regional Stage.

Material. Single specimen, TUG 1393-25, from locality Vasalemma.

Description. Specimen TUG 1393-25 is part of a phragmocone and living chamber $63 \mathrm{~mm}$ in total height, of which $15 \mathrm{~mm}$ is the height of the phragmocone and $48 \mathrm{~mm}$ is the height of the living chamber. The maximum dorso-ventral diametre of the base of the living chamber is 40 $\mathrm{mm}$. The shell is sculptured by straight and directly transverse, coarse lirae ( 1 or 2 per $\mathrm{mm}$ at the diametre of $35 \mathrm{~mm}$ ).

Remarks. The specimen is similar to the previously described species with respect to general shell morphology and shell parametres. However, the strong compression of the specimen inhibits a more precise comparison.

Family Oncoceratidae Hyatt, 1884

Genus and species indet

(Fig. 24C)

Material. Specimen, GIT 147-5b, from locality Vasalemma.

Description. Specimen GIT 147-5b is part of a phragmocone and living chamber $23 \mathrm{~mm}$ in total height, of which $14 \mathrm{~mm}$ is the height of the phragmocone and $9 \mathrm{~mm}$ is the height of the preserved fragment of the living chamber. The phragmocone is compressed in cross-section. At the most adoral part, the phragmocone measures $13 \mathrm{~mm}$ dorso-ventrally and $10 \mathrm{~mm}$ laterally. At the most apical part, the phragmocone measures $9 \mathrm{~mm}$ dorso-ventrally and $8 \mathrm{~mm}$ laterally. Ratio of lateral and dorsal diametres at the adoral part of the shell is 0.77 . Ratio of lateral and dorsal diametres at the apical part of the shell is 0.89 . The sutures are straight and directly transverse. Six phragmocone chambers correspond to the respective shell diametre (rch 0.16). The siphuncle is at the convex side of the shell in position, marginal, almost in contact with the shell wall. cross-section of the siphuncle was probably circular. Its diametre at the septal foramen is 0.03 and diametre at the position of the maximum expansion 0.05 of the corresponding phragmocone diametre (scr 0.5, rss 0.6). The septal necks are achoanitic. The connecting rings are thin like in other oncoceratids, homogenous and slightly expanded. The fragment of the living chamber is 9 $\mathrm{mm}$ in height and does not show any constriction or aperture. It is curved in shape.

Remarks. The overall shape and proportions of the shell and presence of siphuncle on the concave side of the side of the shell curvature suggests assignment to the order Oncocerida, family Oncoceratidae. However, it is not possible to assign the specimen to any lower-rank taxa because no parts of the adult body chamber are preserved.

Order Oncocerida Flower, in Flower \& Kummel 1950 Family, genus and species indet 
Material. Specimen TUG 939-55, from locality Vasalemma, northern Estonia, Vasalemma Formation, Keila Regional Stage.

Description. Specimen TUG 939-55 is part of a phragmocone and living chamber $75 \mathrm{~mm}$ in total height, of which $10 \mathrm{~mm}$ is the height of the phragmocone. The living chamber is $65 \mathrm{~mm}$ in height and is incomplete (aperture not preserved). It is curved and breviconic in shape. The maximum diametre at adapical third is $42 \mathrm{~mm}$ dorso-ventrally. The maximum diametre at about the middle part of the living chamber is $43 \mathrm{~mm}$ dorso-ventrally, and $45 \mathrm{~mm}$ laterally. The maximum diametre at adoral third is $40 \mathrm{~mm}$ dorso-ventrally, and and $41 \mathrm{~mm}$ laterally. Ratio of lateral and dorsal diametres of the shell is c. one. The sutures are straight and directly transverse. Thirteen phragmocone chambers correspond to the respective shell diametre (rch 0.08). The siphuncle is marginal, at the convex side of the shell.

Remarks. The overall shape and proportions of the shell and presence of siphuncle on the concave side of the side of the shell suggests assignment to the order Oncocerida. However, the specimen is poorly preserved and cut by previous researchers in such a manner that it is not possible to assign the specimen to any lower-rank taxa.

\section{Order, family, genus and species indet}

(Fig. 16B)

Diagnosis. Shell straight, with a low angle of expansion $\left(1.3^{\circ}\right)$, short phragmocone chambers (twenty-one chambers to respective shell diametre, rch 0.05) and thick shell wall. Septal necks short, cyrtochoanitic, free ventrally, recumbent dorsally. Septal foramen wide (scr 0.9).

Material. Specimen GIT 222-578, from the locality Vasalemma, northern Estonia, Vasalemma Formation, Keila Regional Stage.

Description. Specimen GIT 222-578 is a part of phragmocone and the living chamber $43.6 \mathrm{~mm}$ in total height, with the maximum diametre of 19 and minimum diametre of $18 \mathrm{~mm}$. The shell is straight and circular in cross-section. The angle of expansion is $1.3^{\circ}$. The sutures are straight and directly transverse. Twenty-one phragmocone chambers correspond to the respective shell diametre (rch 0.05). The siphuncle is subcentral in position ( $\mathrm{rsp} 0.3$ ). cross-section of the siphuncle is circular. Its diametre at the septal foramen is 0.1 and diametre at the position of the maximum expansion is 0.11 relative to the phragmocone diametre (scr 2.5). The septal necks are cyrtochoanitic, short, free ventrally and recumbent dorsally. The connecting rings are homogenous and expanded (Fig. 4D). Endosiphuncular deposits and cameral deposits were not observed. The shell is smooth. The living chamber is long, $38 \mathrm{~mm}$ in height (twice the maximum shell diametre) and it is almost complete, showing constriction in its central part and margin of the aperture.

Remarks. Combination of short phragmocone chambers, straight shell with low angle of expansion and a wide siphuncle with cyrtochoanitic septal necks does not allow a further taxonomic determination of the specimen.

\section{Results}

\section{Taphonomy and preservation}

All cephalopods collected from the Vasalemma Formation, and described herein are from within the reefal limestones and not from the echinoderm grainstone facies. The cephalopods occur as concentrations in decimetre to metre-sized pockets within the massive reef core limestone. The 
reef core limestone is a wackestone, packstone, framestone, and/or boundstone with echinoderm holdfasts, bryozoans and receptaculites as main skeletal components (Kröger et al. 2014a). The pockets are areas within the core limestone, which are in many places filled with laminar argillaceous or silty limestone to marl, and on the top by massive sparite, and are rich in either illeanid trilobite carapaces or chaotically oriented cephalopod shells (Fig. 25). Similar, but larger pockets are known from the mud mounds of the Boda Limestone Formation (late Katian to early Hirnantian), Sweden (Suzuki \& Bergström 1999).

The cephalopod shells are in many places filled with geopetal sparite. Almost all of the cephalopod shells are broken and recrystallised to calcite, nearly one sixth of them $(15 \%, n=30$ of 198) are partially encrusted by epibionts (Data Supplement 4). The main encrusters were bryozoans $(87 \%$ of the encrusted specimens, $n=26)$, but holdfasts of echinoderms and tubular organisms (conulariids?) are also present. The intensity of epibiont overgrowth varies significantly between taxa (standard deviation $=0.21$ with mean rate $=0.34$ ), it is most intense in breviconic an coiled forms (discosorids, oncocerids, tarphycerids), and the least intense in the actinocerid Orthonybyoceras Shimizu \& Obata, 1935 (Data Supplement 4). There is no trend between epibiont intensity and the relative abundance of different encrusters. The epibionts are equally distributed along the circumference of the shell and do not show any shell preferred position. Few of the shells show traces of bioerosion, such as sponge borings.

\section{Diversity}

The cephalopods of the Vasalemma Formation comprise a number of 22 identifiable species that belong to 13 genera, 10 families, and seven orders. A comparison of the fauna with other Ordovician cephalopod assemblages demonstrates that the Vasalemma cephalopods are extraordinarily rich in terms of taxonomic richness, evenness and taxonomic distinctness (Data Supplement 3). The estimates are among the highest known from the Ordovician. Only the assemblage of the late Katian-Hirnantian Boda Limestone Formation has consistently higher estimates. A comparison of these two highly diverse assemblages must take into account that the Boda Limestone represents a considerably longer depositional interval. The reef limestone of the Vasalemma Formation was deposited in a time interval that represents the rising limb of the GICE only (which is considerably less than $1 \mathrm{My}$, Sell et al. 2015). In contrast, the Boda Limestone deposition lasted throughout the entire Ka4 Stage Slice of Bergström et al. (2009) and the earliest Hirnantian, which represents a time interval of more than 3 My (Cooper et al. 2012). The dominant cephalopod genus in the Vasalemma Formation is the small actinocerid Orthonybyoceras Shimizu \& Obata, 1935 , which constitutes $66 \%$ of all specimens. The ribbed orthocerid Striatocycloceras Kröger \& Isakar, 2006 is the second most abundant (18\% of the total number of specimens), and the tarphycerid Discoceras Barrande, 1867 constitutes $15 \%$ of the specimens. Endocerids are completely absent.

The abundance distribution at generic level reflects the more general distribution at ordeal level (Fig. 26) with actinocerids, orthocerids and tarphycerids beeing the three dominant orders. Relative abundance data are not available for many Ordovician cephalopod assemblages, which makes comparison difficult. But, a global comparison of Late Ordovician occurrence data demonstrates that actinocerids are generally more widespread in shallow depositional settings (Kröger et al. 2009) and typical for low palaeo-latitudes (Kröger 2013a), which is in agreement with the data from the Vasalemma Formation.

The relative diversity of the Vasalemma cephalopod orders can be directly compared with several near-contemporaneous assemblages from published sources (Data Supplement 3). The 
results of a cluster analysis and subsequent pca reveals a pattern, which closely resembles a pattern recently found in late Sandbian/early Katian brachiopods (Candela 2015; Sohrabi \& Jin 2013). The Vasalemma assemblage clusters within a nested group that includes late Sandbian/early Katian assemblages from epicontinental Laurentia (north-eastern US, Mid US; Ontario, Canada). By contrast, the late Sandbian/early Katian cephalopods of the Oslo-Asker district, Norway cluster with contemporaneous faunas of the Appalachians (Virginia, Pennsylvania, Maryland). The main difference between these two main clusters, which can be termed Baltica-epicontinental Laurentia (BELB, see also Sohrabi \& Jin 2013) and BalticaAppalachians (BAPP) is the dominance of actinocerids in the former (see Fig. 27).

\section{Palaeogeography}

The species endemicity of the Vasalemma cephalopods is high, a number of 17 of the total of 22 identified species are exclusively known from the Vasalemma Formation. This high rate is probably an artefact, because contemporaneous cephalopod assemblages from elsewhere in the Baltoscandian Region are poorly known. The generic composition of the Vasalemma cephalopods is less endemic and allows for cluster analysis and subsequent pca with contemporaneous assemblages (Fig. 28). In a Raup-Crick clustering (see Methods paragraph) the Vasalemma cephalopods form a group with contemporaneous assemblages from North China and Australia which is contrasted with a more consistent group that includes the Laurentian assemblages, and with a third group that is less consistent and represents assemblages from the South China Craton and the Oslo-Asker district, Norway. The pca reveals that Hoeloceras and the tarphycerids are responsible for the Vasalemma-North China cluster. Tarphycerids, such as Discoceras and Trocholites Conrad, 1838 are generally very widespread genera, but they are absent or rare in many Laurentian assemblages during the Sandian/Katian (Kröger 2013a). This is in general agreement with the Sandbian brachiopod palaeogeography, in which an AngloWelsh Baltic Province was distinguished, that includes the North and South China cratons (Harper et al. 2013).

It is an interesting detail that nine of the eleven non-endemic cephalopod genera of the Vasalemma Formation have their earliest occurrence within Baltica, (Isorthoceras Flower, 1962, herein; Ordogeisonoceras Frey, 1995, herein; Orthonybyoceras Shimizu \& Obata, 1935, herein; Pleurorthoceras Flower, 1962, herein; Striatocycloceras; Kröger \& Isakar, 2006; Trocholites; Sweet, 1958), in Siberia, (Hemibeloitoceras Balashov, 1962), and in the South and North China Craton (Beloitoceras Foerste, 1924, Lai 1981, 1982; Hoeloceras Sweet, 1958, Chen \& Liu 1976) and migrated only during the Katian towards Laurentia.

\section{Interpretation}

The cephalopod assemblage of the Vasalemma Formation, described herein, is interpreted as parauthochtonous, representing the original reef dwelling fauna or a fauna of cephalopods that lived in the close vicinity of the Vasalemma reefs. The cephalopod shells are almost exclusively from shelly concentrations in syndepositional cavities, which are called 'pockets' in Palaeozoic reef settings elsewhere (e.g. Philcox 1970; Racki 1990; Suzuki \& Bergström 1999, Kröger et al. 2014a). The shell concentrations can be best explained as shells that were washed in or trapped in syndepositionary cavities (Kröger \& Ebbestad 2014). Taphonomic experiments and observations in Recent Nautilus indicate that small shells (diametre $<175 \mathrm{~mm}$ ) get flooded and submerge within a few days after dead (Wani et al. 2005). Additionally, Nautilus shells, which were deposited in shallow subtidal reefal environments of today are characterised by an 
extremely high percentage ( $>95 \%$ ) of post-mortem epizoan infestation (Mapes et al. 2010). This is similar to the relative high abundance of epizoan encrustation of the Vasalemma cephalopods (Data Supplement 4). Cephalopods of pocket concentrations from mud mounds of the co-eval Kullsberg limestone (see Calner et al. 2010) and from the Boda Limestone (late KatianHirnantian, Kröger 2013b) from Sweden are almost free of epibionts (personal observation BK, MA). Hence, the preservational features of the Vasalemma cephalopods support the general interpretation of the depositional setting of the Vasalemma reefs as shallow subtidal based on sedimentary features (Kröger et al. 2014a).

Several reports on Ordovician cephalopod shell encrustation interpret the majority of epizoans as syn-vivo (Baird et al. 1989; Kröger et al. 2009; Wyse-Jackson \& Key 2014; Wyse-Jackson et al. 2014). These reports focus on bryozoans exclusively. The majority of epizoans on the shells of Vasalemma cephalopods are bryozoans $(87 \%)$. We did not distinguish between syn-vivo and post-mortem incrustation in our analysis and there is no significant relation between incrustation intensity and echinoderm holdfast abundance, which can be considered as always post-mortem, and thus could give more evidence for the timing of the incrustation. However, the significant differences in incrustation intensity in between the cephalopod groups suggest differences in either post-mortem drift and (re-) deposition and/or life habitat. The breviconic cephalopods have more than $30 \%$ of shells infested with epizoans, in contrast, less than $5 \%$ are infested in Orthonybyoceras. This either indicates longer drifting periods of the breviconic and coiled shells or different life styles.

The taxonomic composition of the Vasalemma cephalopod assemblage with a dominance of actinocerids and an absence of endocerids is in agreement with a warm water (tropical or subtropical) shallow subtidal depositional environment (Kröger et al. 2009; Kröger 2013a). The Vasalemma assemblage is in strong contrast to the younger and deeper water reef-related assemblage of the Boda Limestone Formation (late Katian-early Hirnantian), central Sweden, which is dominated by orthocerids and barrandeocerids, and in which actinocerids are completely absent. The comparison of the Vasalemma cephalopod assemblage with other late Sandbian cephalopod assemblages supports this general impression (Fig. 27). The cephalopod diversity distribution results in two main late Sandbian faunal clusters (BELB, and BAPP), which is in a perfect agreement with taxonomic brachiopod clusters (Sohrabi \& Jin 2013). These two clusters also agree with the south-eastern, central Laurentia, and Scoto-Appalachian brachiopod clusters (Candela 2015) and with an earlier geochemistry based distinction between a Midcontinent and Taconic Aquafacies (Holmden et al. 1998). The causes for the clear distinction of the brachiopod faunas are discussed controversially (see review in Candela 2015). Our new cephalopod data support the interpretation of the BELB and BAPP clusters as mainly controlled by water temperature and depositional depth (see also Sohrabi \& Jin 2013).

The stratigraphic interpretation of the Vasalemma Formation as representing the terminal Sandbian (see above) allows for a refined analysis and interpretation of migration pattern and evolutionary faunal changes across the Sandbian / Katian stages boundary. The Sandbian / Katian boundary is roughly equivalent with the Keila / Oandu regional stage boundary in Baltoscandia and probably the prominent boundary between the M4/M5 depositional sequences (base of the Lexington Limestone, see Sell et al. 2015) in eastern North America and the boundary DS VII/VIII or Frognerkilen Lowstand, (Dronov et al. 2011; Nielsen 2011, respectively) in Baltoscandia. The Sandbian / Katian boundary also marks one of the most drastic faunal turnover events in the east Baltic palaeobasin with microfaunal crisis during the Oandu Stage and a subsequent appearance of many new taxa in the post-Oandu interval (Ainsaar 
et al. 2004; Hansen \& Harper, 2008). Previous comparisons of Baltoscandian faunas of this time interval emphasised on a Laurentian origin of some of the immigrants during these events (Hansen \& Harper, 2008; Kaljo et al. 2007). The cephalopod assemblage from the Vasalemma Formation tells a different story, because most of the genera known from the Vasalemma Formation have their first record on Baltica, and/or the South and North China cratons and migrated only during the Katian towards Laurentia. A similar early Katian immigration trend toward Laurentia was recognised also for ostracods (Mohibullah et al. 2010). The cephalopod migration pattern indicates that the northward shift of Baltica and the the concomitant closing of the Iapetus Ocean during the Mid-Late Ordovician caused not a one-way immigration route but affected the Late Ordovican faunas of Laurentia and Baltica alike.

\section{Acknowledgements}

We are indebted for the support by the Deutsche Forschungsgemeinschaft (grant KR 2095/7-1). BK is grateful to Mare Isakar for many years of support during fieldwork and collection trips in Estonia and for being such a good company. We thank Ursula Toom (Tallinn, Estonia), Gennadi Baranov (Tallinn, Estonia) for help in the collections and Olle Hints and Linda Hints (Tallinn, Estonia) for general support. We thank Helena Korkka (Helsinki, Finland) for help with the preparation of the specimens. MA is very grateful to Tõnu Meidla (Tartu, Estonia) for the essential support, useful advice and kind help during her stay and work at the collections and to Vojtěch Turek and Michal Kubajko (Prague, Czech Republic) for kindly proving several wellpreserved cephalopod specimens from Vasalemma. MA also wants to thank Martin Košt'ák (Prague, Czech Republic) for general help and advices and Mikuláš Muroň (Brno, Czech Republic) for instant support and technical help. This research was further supported by European Social Fund's Doctoral Studies, the Internationalisation Programme DoRa. It recieved support from SYNTHESYS3 which is financed by the European Community-Research Infrastructure Action under the Seventh Framework Programme (FP7/2007-2013, grant agreement $\mathrm{n}^{\circ} 226506$ ). This paper is a contribution to the IGCP 591 project 'The Early to Middle Palaeozoic Revolution'.

\section{References}

Ainsaar. L., Meidla, T. \& Martma, T. 1999. Evidence for a widespread carbon isotopic event associated with late Middle Ordovician sedimentological and faunal changes in Estonia. Geological Magazine, 136(1), 49-62.

Ainsaar. L., Meidla, T. \& Martma, T. 2004. The Middle Caradoc Facies and Faunal Turnover in the Late Ordovician Baltoscandian palaeobasin. Palaeogeography, Palaeoclimatology, Palaeoecology, 210(2-4), 119-133.

Ainsaar, L., Kaljo, D., Martma, T., Meidla, T., Männik, P., Nõlvak, J. \& Tinn, O. 2010. Middle and Upper Ordovician carbon isotope chemostratigraphy in Baltoscandia: a correlation standard and clues to environmental history. Palaeogeography, Palaeoclimatology, Palaeoecology, 294(3), 189-201.

Alroy, J. 2010. Fair sampling of taxonomic richness and unbiased estimation of origination and extinction rates. Quantitative methods in paleobiology. Paleontological Society Papers, 16, 55-80. 
Baird, G.C., Brett, C E \& Frey, R C. 1989. "Hitchhiking" epizoans on orthoconic cephalopods: preliminary review of the evidence and implications. Lethaea Senckenbergiana, 69, 439-465.

Balashov, Z. G. 1953. Svernutye i polivernutye nautiloidei ordovika pribaltiki. Trudy Vsesoyuznogo Neftyanogo Nauchno-Issledovatelskogo Geologo-Razvednoknogo Instituta, 78, 217-268.

Balashov, Z. G. 1962. Ordovician nautiloids from the Siberian platform. Isd. Leningrad University, Leningrad/St. Petersburg, $205 \mathrm{pp}$.

Balashov, Z. G. 1964. Nekotorye nautiloidei endoceratoidei i actinoceratoidei Ordovika Severo-Vostoka SSSR. Ucenye Zapiski Naucno Issledovatelskij Institut Geologii Arktiki Gosudarstvennogo Geologiceskogo Komiteta SSSR, 6, 12-71.

Barrande, J. 1865-1877. Système silurien du centre de la Bohême, Ire partie. Recherches palèontologiques, II. Classe de mollusques, ordre des cèphalopodes. Praha.

Bergström S.M., Chen X., Gutiérrez-Marco J.C. \& Dronov A. 2009. The new chronostratigraphic classification of the Ordovician System and its relation to major regional series and stages and to $\delta^{13} \mathrm{C}$ chemostratigraphy. Lethaia, 42, 97-107.

Bergström, S. M., Young, S. \& Schmitz, B. 2010. Katian (Upper Ordovician) $\delta^{13} \mathrm{C}$ chemostratigraphy and sequence stratigraphy in the United States and Baltoscandia: a regional comparison. Palaeogeography, Palaeoclimatology, Palaeoecology, 296(3), 217-234.

Bergström, S.M., Calner, M., Lehnert, O. \& Noor, A. 2011. A new upper Middle Ordovician-Lower Silurian drillcore standard succession from Borenshult in Östergötland, southern Sweden: 1. Stratigraphical review with regional comparisons. GFF, 133, 149-171.

Bergström, S. M., Lehnert, O., Calner, M. \& Joachimski, M. M. 2012. A new upper Middle Ordovician-Lower Silurian drillcore standard succession from Borenshult in Östergötland, southern Sweden: 2. Significance of $\delta^{13} \mathrm{C}$ chemostratigraphy. GFF, 134(1), 39-63.

Brugiére, J. G. 1789. Histoire naturelle des vers. Vol 1, Pt 1, Encyclopedie methodique 6, Panckoucke, Paris, 757 pp..

Calner, M., Lehnert, O. \& Joachimski, M. 2010. Carbonate mud mounds, conglomerates, and sea-level history in the Katian (Upper Ordovician) of central Sweden. Facies, 56(1), 157-172.

Candela, Y. 2015. Evolution of Laurentian brachiopod faunas during the Ordovician Phanerozoic sea level maximum. Earth-Science Reviews, 141, 27-44.

Chapman, E. J. 1857. On the occurrence of the genus Cryptoceras in Silurian rocks. Annals and Magazine of Natural History, 2nd Series, 20, 114-117, London.

Chen, T. 1987. Ordovician nautiloids from Xainza, northern Xizang. Bulletin of Nanjing Institute of Geology and Palaeontology, 11, 133-191. 
Chen, J. \& Liu, G. 1976. Ordovician nautiloids. Pp. 42-53 in Lu, Y. H., Chu, C. L., Chien, Y. Y., Zhou, Z. Y., Chen, J. Y., Liu, G. W. \& Xu, H. K. (eds.) Ordovician biostratigraphy and palaeozoogeography in China. Memoirs of the Nanjing Institute of Geology and Palaeontology, Academia Sinica, 7, Nanjing.

Clarke, K. R. \& Warwick, R. M. 1999. The taxonomic distinctness measure of biodiversity: weighting of step lengths between hierarchical level. Marine Ecology Progress Series, 184, 21-29.

Conrad, T. A. 1838. Report of the Palaeontological Department of the Survey. New York State Geological Survey, Annual Report, 2, 107-119.

Conrad, T. A. 1842. Observations on the Silurian and Devonian systems of the United States, with descriptions of new organic remains. Journal of the Academy of Natural Sciences of Philadelphia, 8, 229-280.

Cooper, R.A., Sadler, P.M., Hammer, O. \& Gradstein, F.M. 2012. Chapter 20-The Ordovician Period. Pp. 489523 in Gradstein, F.M., Schmitz, J.G.O.D. \& Ogg, G.M. (eds.) The Geologic Time Scale 2012. Boston, Elsevier.

Dronov, A. V., Ainsaar, L., Kaljo, D., Meidla, T., Saadre, T. \& Einasto, R. 2011. Ordovician of Baltoscandia: facies, sequences and sealevel changes. Pp. 143-150 in Gutiérrez-Marco, J. C., Rábano, D., Gárcia-Bellido, D. (eds) Ordovician of the World. 11th International Symposium on the Ordovician System, Cuademos del Museo Geominero 14, Instituto Geologógico y Minero de Espana, Madrid.

Dzik, J. 1984. Phylogeny of the Nautiloidea. Palaeontologia Polonica, 45, 1-203.

Ebbestad, J.O.R. \& Högström, A E S. 2007. Ordovician of the Siljan District, Sweden. WOGOGOB 2007, 9th meeting of the Working Group on Ordovician geology of Baltoscandia, Field Guide and Abstracts, 128, 52-58.

Eichwald, E. 1840. Über das silurische Schichtensystem in Esthland. Zeitschrift für Natur- und Heilkunde Medizinische Akademie zu St. Petersburg, 1/2, 1-210.

Eichwald, E. 1842. Die Urwelt Russlands durch Abbildungen erlaeutert. 2. Heft. Neuer Beitrag zur Geognosie Esthlands und Finlands. Akademie der Wissenschaften, St. Petersburg, 184 pp.

Eichwald, E. 1854. Die Grauwackenschichten von Liev- und Ehstland. Bulletin de la Societe Imperiale des Naturalistes de Moscou, 27(1), 1-111.

Eichwald, E. 1860. Lethaea Rossica ou Paléontologie de la Russie. Stuttgart, Schweizerbart, 1654 pp.

Evans, D. H. 2002. Some additional Ordovician and Silurian cephalopods from Ireland. Special papers in palaeontology, 67, 77-96.

Flower, R. H. 1941. Development of the mixochoanites. Journal of Paleontology, 15(5), 523-548.

Flower, R. H. 1946. Ordovician cephalopods from the Cincinnati region. Part 1. Bulletins of American Paleontology, 26(116), 3-547.

Flower, R. H. 1952. New Ordovician cephalopods from eastern North America. Journal of Paleontology, 26, 2459. 
Flower, R. H. 1957. Study of the Actinoceratida, I. The Ordovician development of the Actinocerida, with notes on actinoceroid morphology and Ordovician stratigraphy. New Mexico Institute of Mining and Technology, State Bureau of Mines and Mineral Resources, Bulletin, 2, 3-60.

Flower, R. H. 1962. Part 1, Revision of Buttsoceras. Part 2, Notes on the Michelinoceratida. State Bureau of Mines and Mineral Resources, New Mexico Institute of Mining and Technology, Memoir, 10, 1-58.

Flower, R. H. \& Kummel, B. 1950. A classification of the Nautiloidea. Journal of Paleontology, 24, 604-616.

Foerste, A. F. 1917. Notes on Richmond and related fossils. Journal of the Cincinnati Society of Natural History, $22,42-55$.

Foerste, A. F. 1924. Notes on American Paleozoic cephalopods. Denison University Bulletin, Journal of the Scientific Laboratories, 20, 193-268.

Foerste, A. F. 1925. Notes on Cephalopod genera, chiefly coiled Silurian forms. Journal of the Scientific Laboratories of Denison University, 21, 1-69.

Foerste, A. F. 1930. Three studies on cephalopods. Journal of the Scientific Laboratories of Denison University, 24, $265-381$.

Foerste, A. F. 1933. Black River and other cephalopods from Minnesota, Wisconsin, Michigan, and Ontario (Part 2). Denison University, Bulletin, Journal of Scientific Laboratories, 28, 1-136.

Foerste, A. F. 1936. The cephalopods of the Maquoketa Shale of Iowa. Journal of the Scientific Laboratories of Denison University, 30, 231-257.

Foerste, A. F. \& Teichert, C. 1930. The Actinoceroids of East-central North America. Denison University Bulletin, Journal of the Scientific Laboratories, 25, 201-296,

Furnish, W. M. \& Glenister, B. F. 1964. Tarphycerida. Pp. K343-K368 in Moore, R.C. (ed) Treatise on invertebrate paleontology. Part K. Mollusca 3. Endoceratoidea, Actinoceratoidea, Nautiloidea, Bactritoidea. GSA et University of Kansas Press, Lawrence, Kansas.

Frey, R. C. 1995. Middle and Upper Ordovician Cephalopods of the Cincinnati Region of Kentucky, Indiana, and Ohio. United States Geological Survey Professional Paper 1066P, 119 pp.

Ghavidel-Syooki, M., Evans, D. H., Ghobadi Pour, M., Popov, L. E., Álvaro, J. J., Rakhmonov, U., Klishevich, I. A. \& Ehsani, M. H. 2015. Late Ordovician cephalopods, tentaculitides, machaeridians and echinoderms from

Kuh-e Faraghan, High Zagros, Iran, Alcheringa: An Australasian Journal of Palaeontology, 39(4), $530-549$.

Goldman, D., Leslie, S. A., Nõlvak, J., Young, S., Bergström, S. M. \& Huff, W. D. 2007. The global stratotype section and point (GSSP) for the base of the Katian Stage of the Upper Ordovician Series at Black Knob Ridge, Southeastern Oklahoma, USA. Episodes, 30(4).

Hall, J. 1847. Natural History of New York, Paleontology, Volume 1, containing Descriptions of the Organic Remains of the Lower Division of the New York System (Equivalent of the Lower Silurian Rocks 
of Europe). Van Benthuysen, Albany, New York.

Hall, J. 1861. Report of the superintendent of the (Wisconsin) Geological Survey, exhibiting the progress of the work, January 1, 1861 (including the descriptions of new species of fossils from the investigations of the Survey). E. A. Calkins and Co, Madison, Wisconsin.

Hall, J. 1877. Cephalopoda. Pp. 284 in Miller, S. A. (ed.) The American Palaeozoic fossils: a catalogue of the genera and species, with names of authors, dates, places of publication, groups of rocks in which found, and the etymology and signification of the words, and an introduction devoted to the stratigraphical geology of the Palaeozoic rocks. Privately published, Cincinnati, Ohio.

Hansen, J. \& Harper, D. A. T. 2008. The late Sandbian-earliest Katian (Ordovician) brachiopod immigration and its influence on the brachiopod fauna in the Oslo Region, Norway. Lethaia, 41, 25-35.

Hansen, J., Kresten Nielsen, J. \& Hanken, N.-M. 2009. The relationships between Late Ordovician sea-level changes and faunal turnover in western Baltica: Geochemical evidence of oxic and dysoxic bottom-water conditions. Palaeogeography, Palaeoclimatology, Palaeoecology, 271, 268-278.

Harper, D.A.T., Rasmussen, C.M.Ø., Liljeroth, M., Blodgett, R.B., Candela, Y., Jin, J., Percival, I.G., Rong, J.-, Villas, E. \& Zhan, R. 2013. Chapter 11 Biodiversity, biogeography and phylogeography of Ordovician rhynchonelliform brachiopods. Geological Society, London, Memoirs, 38, 127-144.

Holmden, C., Creaser, R.A., Muehlenbachs, K., Leslie, S.A. Kaljo, D., Hints, L., Martma, T., Nõlvak, J. \& Bergström, S.M. 1998. Isotopic evidence for geochemical decoupling between ancient epeiric seas and bordering oceans: Implications for secular curves. Geology, 26, 567-570.

Hyatt, A. 1884. Genera of fossil cephalopods. Proceedings of the Boston Society of Natural History, 22, 253-338.

Kaljo, D., Hints, L., Martma, T., Nõlvak, J. \& Oraspõld, A. 2004. Late Ordovician carbon isotope trend in Estonia, its significance in stratigraphy and environmental analysis. Palaeogeography, Palaeoclimatology,

Palaeoecology, 210(2-4), 165-185.

Kaljo, D., Martma, T. \& Saadre, T. 2007. Post-Hunnebergian Ordovician carbon isotope trend in Baltoscandia, its environmental implications and some similarities with that of Nevada. Palaeogeography, Palaeoclimatology,

Palaeoecology, 245, 138-155.

Korn, D. \& Klug, C. 2003. Morphological pathways in the evolution of Early and Middle Devonian ammonoids. Paleobiology, 29(3), 329-348.

Korn, D. \& Klug, C. 2007. Conch form analysis, variability, morphological disparity, and mode of life of the Frasnian (Late Devonian) ammonoid Manticoceras from Coumiac (Montagne Noire, France). Pp. 57-85 in Landman, N. H., Davis, R. A. \& Mapes, R.H. (eds) Cephalopods present and past: new insights and fresh perspectives. Springer Netherlands.

Kröger, B. 2004. Revision of Middle Ordovician orthoceratacean nautiloids from Baltoscandia. Acta Palaeontologica Polonica, 49, 57-74. 
Kröger, B. 2013a. Chapter 27 Cambrian-Ordovician cephalopod palaeogeography and diversity. Pp. 428-429 in Servais, T. \& Harper, D.A.T. (eds) Early Palaeozoic Biogeography and Palaeogeography. Geological Society, London, Memoirs, 38.

Kröger, B. 2013b. The cephalopods of the Boda Limestone, Late Ordovician, of Dalarna, Sweden. European Journal of Taxonomy, 41, 1-110.

Kröger, B. \& Isakar, M. 2006. Revision of annulated orthoceridan cephalopods of the Baltoscandic Ordovician. Fossil Record, 9, 139-165.

Kröger, B., Servais, T. \& Zhang, Y. 2009. The origin and initial rise of pelagic cephalopods in the Ordovician. PLoS ONE, 4(9), e7262.

Kröger, B., Hints, L. \& Lehnert, O. 2014a. Age, facies, and geometry of the Sandbian/Katian (Upper Ordovician) pelmatozoan-bryozoan-receptaculitid reefs of the Vasalemma Formation, northern Estonia. Facies, 60(4), 963-986.

Kröger, B., Hints, L., Lehnert, O., Mannik, P. \& Joachimski, M. 2014b. The early Katian (Late Ordovician) reefs near Saku, northern Estonia and the age of the Saku Member, Vasalemma Formation. Estonian Journal of Earth Sciences, 63(4), 271-276.

Kröger, B. \& Ebbestad, J.O.R. 2014. Palaeoecology and palaeogeography of Late Ordovician (Katian-Hirnantian) cephalopods of the Boda Limestone, Siljan district, Sweden. Lethaia, 47, 15-30.

Kröger, B., Hints, L. \& Lehnert, O. 2016. Ordovician reef and mound evolution: the Baltoscandian picture. Geological Magazine, 24 pp., DOI: 10.1017/S0016756816000303.

Kuhn, O. 1940. Palaeozoologie in Tabellen. Fischer Verlag, Jena.

Lai, C. 1981. The Upper Ordovician cephalopods of Yaoxian area, Shansi Province. Bulletin of the Chinese Academy of Geological Sciences, 3(1), 85-99.

Lai, C. 1982. Ordovician cephalopods from Xainza, Xizang (Tibet). Acta palaeontologica sinica, 21, 553-559.

Mapes, R.H., Hembree, D.I., Rasor, B.A., Stigall, A., Goirand, C. \& Richer De Forges, B. 2010. Modern Nautilus (Cephalopoda) taphonomy in a subtidal to backshore environment Lifou (Loyalty Islands). PALAIOS, 25, 656-670.

McCoy, F. 1844. A Synopsis of the Characters of the Carboniferous Limestone Fossils of Ireland. University Press, Dublin, 207 pp.

Miller, S.A. 1875. Class Cephalopoda (Cuvier) as represented in the Cincinnati Group. Cincinnati Quarterly Journal of Science, 2(2), 121-134.

Miller, S. A. 1880. Orthoceras dyeri. Journal of the Cincinnati Society of Natural History, 3, 1-236.

Miller, S. A. \& Faber, C. L. 1894. Description of some Cincinnati fossils. The Journal of the Cincinnati Society of Natural History, 17, 137-158. 
Mohibullah, M., Afzal, J., Williams, M., Meidla, T., Siveter, D.J. \& Zalasiewicz, J.A. 2010. Ostracods from Upper Ordovician (Katian) carbonate lithofacies in southwest Scotland. Geological Magazine, 147, 919-939.

Moore, R.C. 1964. Treatise on invertebrate paleontology. Part K. Mollusca 3. Endoceratoidea, Actinoceratoidea, Nautiloidea, Bactritoidea. GSA et University of Kansas Press, Lawrence, Kansas, USA, 519 pp.

Mutvei, H. 2015. Characterization of two new superorders Nautilosiphonata and Calciosiphonata and a new order Cyrtocerinida of the subclass Nautiloidea; siphuncular structure in the Ordovician nautiloid Bathmoceras (Cephalopoda), GFF, 137(3), 164-174.

Mutvei, H. \& Dunca, E. 2011. Siphuncular structure in the orders Tarphycerida and Barrandeocerida (Cephalopoda: Nautiloidea). Palaeontology, 54(3), 705-710.

Neben, W. \& Krüger, H. H. 1971. Fossilien ordovizischer Geschiebe. Staringia, 1, 1-50.

Nielsen, A.T. 2011. A re-calibrated revised sea-level curve for the Ordovician of Baltoscandia. Ordovician of the World: 11th International Symposium on the Ordovician System, Cuadernos del Museo Geominero, 14, 399-402.

Oksanen, J., Guillaume Blanchet, F., Kindt, R., Legendre, P., Minchin, P.R., O’Hara, R.B., Simpson, G.L., Peter, S., Stevens, H.H. \& Wagner, H. 2013. Vegan: Community Ecology Package:

http://CRAN.R-project.org/package=vegan

Opalinski, P. R. \& Harland, T. L. 1981. The Middle Ordovician of the Oslo Region, Norway, 29, Stratigraphy of the Mjøsa Limestone in the Toten and Nes-Hamar areas. Norsk Geologisk Tidsskrift, 61, 59-78.

Pancost, R. D., Freeman, K. H., Herrmann, A. D., Patzkowsky, M. E., Ainsaar, L., \& Martma, T. 2013. Reconstructing Late Ordovician carbon cycle variations. Geochimica et Cosmochimica Acta, 105, 433-454.

Patzkowsky, M. E., Slupik, L. M., Arthur, M. A., Pancost, R. D. \& Freeman, K. H. 1997. Late Middle Ordovician environmental change and extinction: harbinger of the Late Ordovician or continuation of Cambrian patterns? Geology, 25, 911-914.

Philcox, M.E. 1970. Geometry and evolution of the Palisades Reef complex, Silurian of Iowa. Journal of Sedimentary Research, 40, 171-183.

Portlock, J. E. 1843. Report on the geology of the county of Londonderry and parts of Tyrone and Fermanagh. 784 pp., Dublin.

Quinton, P. C., Percival, I. G., Zhen, Y. Y. \& Macleod, K. G. 2015. Ordovician temperature trends: constraints from $\delta^{18} \mathrm{O}$ analysis of conodonts from New South Wales, Australia. Stratigraphy, 12(2), 62-67.

Racki, R. 1990. Frasnian/Famennian event in the Holy Cross Mts, Central Poland: stratigraphic and ecologic aspects. Pp. 169-181 in Kauffman, E. \& Walliser, O. (eds.) Extinction Events in Earth History.

Raymond, P. E. 1916. The correlation of the Ordovician strata of the Baltic Basin with those of Eastern North America. Bulletin of the Museum of Comparative Zoology at Harvard College, 7(3), 179-286. 
Remelé, A. 1880. Über einige neue oder seltene Versteinerungen aus silurischen Diluvialgeschieben der Gegend von Eberswalde. Festschrift für die Fünfzigjahrfeier der Forstakademie Eberswalde. Eberswalde, 179-252.

Ruedemann, R. 1912. The Lower Siluric shales of the Mohawk Valley. Albany Educational Department, New York State Museum Bulletin, 162, 1-151.

Saemann, L. 1853. Über die Nautiliden. Palaeontographica, 3, 121-167.

Schmidt, F. 1881. Revision der ostabaltischen silurischen Trilobiten nebst geognostischer Übersicht des ostbaltischen Silurgebiets. Abt. I. Phacopiden, Cheiruriden und Encrinuriden. Mémoires de l'Academie Imperiale des Sciences de St. Petersburg, 7(30), 1-238.

Schröder, H. 1891. Untersuchungen über silurische Cephalopoden. Palaeontologische Abhandlungen, Neue Folge, 1(4), 1-48.

Sell, B., Ainsaar, L. \& Leslie, S. 2013. Precise timing of the Late Ordovician (Sandbian) super-eruptions and associated environmental, biological, and climatological events. Journal of the Geological Society, 170, 711-714.

Sell, B. K., Samson, S. D., Mitchell, C. E., McLaughlin P. I. Koenig. A. E. \& Leslie, S. A. 2015. Stratigraphic correlations using trace elements in apatite from Late Ordovician (Sandbian-Katian) K-bentonites of eastern North America. Geological Society of America Bulletin, 127(9-10), 1259-1274.

Shimizu, S. \& Obata, T. 1935 On Some New Genera of Ordovician Nautiloids from East Asia. The Journal of the Shanghai Science Institute, sect. 2, 2, 11-25.

Sohrabi, A. \& Jin, J. 2013. Global palaeobiogeography of brachiopod faunas during the early Katian (Late Ordovician) greenhouse episode. Palaeogeography, Palaeoclimatology, Palaeoecology, 389, 78-86.

Stumbur, H. A. 1962. Rasprostranenie nautiloidei v ordovike Estonii (s opisaniem nekotorykh novykh rodov). Trudy Instituta Geologii Akademii Nauk Estonskoi SSR (ENSV Teaduste Akadeemia Geoloogia Institundi Uurimused), 10, 131-147.

Strand, T. 1934. The Upper Ordovician Cephalopods of the Oslo Area. Norsk Geologiske Tidsskrift, 14, 1-117.

Suzuki, Y. \& Bergström, J. 1999. Trilobite taphonomy and ecology in Upper Ordovician carbonate buildups in Dalarna, Sweden. Lethaia, 32(2), 159-172.

Sweet, W. C. 1958. The Middle Ordovician of the Oslo region of Norway. 10. Nautiloid cephalopods. Norsk Geologiske Tidsskrift, 31, 1-178.

Teichert, C. 1933. Der Bau der actinoceroiden Cephalopoden. Palaeontographica, A, 77, 111-230.

Teichert, C. 1964. Actinoceratoidea. Pp. K190-K216 in Moore, R.C. (ed) Treatise on invertebrate paleontology. Part K. Mollusca 3. Endoceratoidea, Actinoceratoidea, Nautiloidea, Bactritoidea. GSA et University of Kansas Press, Lawrence, Kansas, USA.

Torsvik, T. H. 2011. BugPlates: Linking Biogeography and Palaeogeography. Updated at: http://www.geodynamics.no/Web/Content/Software 
Tuuling, I. \& Flodén, T. 2000. Late Ordovician carbonate buildups and erosional features northeast of Gotland, northern Baltic Sea. $G F F$, 122(2), 237-249.

Ulrich, E. O., Foerste, A. F., Miller, A. K. \& Furnish, W. M. 1942. Ozarkian and Canadian Cephalopods Part I: Nautilicones. Geological Society of America Special Papers, 37, 1-157.

Wani, R., Kase, T., Shigeta, Y. \& De Ocampo, R. 2005. New look at ammonoid taphonomy, based on field experiments with modern chambered nautilus. Geology, 33(11), 849-852.

Whiteaves, J. F. 1891. Descriptions of Some New or Previously Unrecorded Species of Fossils from the Devonian Rocks of Manitoba. Transactions of the Royal Society of Canada, 8(4), 93-110.

Whitfield, R. P. 1886. Notice of Geological investigations along the Eastern shore of Lake Champlain, conducted by Prof. H. M. Seeley and Prest. Ezra Brainerd, of Middlebury College, with descriptions of the new Fossils discovered. Bulletin of the American Museum of Natural History, 1, 293-345.

Wyse-Jackson, P.N. \& Key, M.M. 2014. Epizoic bryozoans on cephalopods through the Phanerozoic: a review. Studi Trentini di Scienze Naturali, 94, 283-291.

Wyse-Jackson, P.N., Key Jr, M.M. \& Coakley, S.P. 2014. Epizoozoan trepostome bryozoans on nautiloids from the Upper Ordovician (Katian) of the Cincinnati Arch region, U.S.A.: an assessment of growth, form, and water flow dynamics. Journal of Paleontology, 88, 475-487.

Young, S. A., Saltzman, M. R., \& Bergström, S. M. 2005. Upper Ordovician (Mohawkian) carbon isotope $\left(\delta^{13}\right.$ C) stratigraphy in eastern and central North America: Regional expression of a perturbation of the global carbon cycle. Palaeogeography, Palaeoclimatology, Palaeoecology, 222(1), 53-76.

Young, S. A., Saltzman, M. R., Bergström, S. M., Leslie, S. A. \& Xu, C. 2008. Paired $\delta^{13} \mathrm{C}$ carb and $\delta^{13} \mathrm{C}$ org records of Upper Ordovician (Sandbian-Katian) carbonates in North America and China: implications for paleoceanographic change. Palaeogeography, Palaeoclimatology, Palaeoecology, 270(1), 166-178.

Young, S., A., Saltzman, M., R., Ausich, W., I., Desrochers, A. \& Dimitri, K. 2010. Did changes in atmospheric $\mathrm{CO}^{2}$ coincide with latest Ordovician glacial-interglacial cycles? Palaeogeography, Palaeoclimatology,

Palaeoecology, 296, 376-388.

Zhang, Y. \& Chen T. 2002. Ordovician nautiloids from Lijiang, Yunnan, southwest China. Acta Palaeontologica Sinica, 1, 007.

Zhuravleva, F. A. 1959. On the family Michelinoceratidae. Materialii k Osnovam Paleontologii, 3, 47-48.

\section{Figure captions}

Table 1. List of measured and calculated parameters used to describe the morphology of the studied specimens. * from Frey (1995), ${ }^{\#}$ from Korn \& Klug (2007).

\begin{tabular}{|l|l|l|}
\hline Parameter & Abbrevation & Calculation \\
\hline Minimum diameter of the shell & dmin &
\end{tabular}




\begin{tabular}{|c|c|c|}
\hline Maximum diameter of the shell & dmax & \\
\hline Height of the specimen & $\mathrm{h}$ & \\
\hline $\begin{array}{l}\text { Siphuncle diameter at the position of } \\
\text { the septal foramen }\end{array}$ & sdmin & \\
\hline $\begin{array}{l}\text { Siphuncle diameter at the position of } \\
\text { the maximum expansion }\end{array}$ & sdmax & \\
\hline $\begin{array}{l}\text { Distance of the siphuncle from the } \\
\text { shell wall }\end{array}$ & sdist & \\
\hline Angle of expansion & $\begin{array}{l}\text { e } \\
2^{*}((\text { Arctange } \\
\mathrm{ns}(((\mathrm{dmax}- \\
\mathrm{dmin}) / 2) / \mathrm{h}))^{*} \\
180) / \Pi\end{array}$ & \\
\hline Relative chamber height & rch & chamber height/corresponding diameter \\
\hline Relative siphuncular shape & rss & sdmin/sdmax \\
\hline Siphuncle compression ratio & $\mathrm{scr}^{*}$ & sdmax/corresponding chamber height \\
\hline Relative siphuncular position & rsp & $\begin{array}{l}\text { sdist/corresponding diameter } \\
(<0.5, \text { ventrally shifted; }=0.5, \text { central; }>0.5 \\
\text { dorsally shifted })\end{array}$ \\
\hline Relative siphuncular diameter & rsd & Sdmin/corresponding dmax \\
\hline Shell diameter of a coiled shell & $\mathrm{dm} 1$ & \\
\hline Shell diameter at dm1-180 & $\mathrm{dm} 2$ & \\
\hline Width at dm1 & ww1 & \\
\hline Width at dm2 & ww2 & \\
\hline Height at dm1 & wh1 & \\
\hline Height at dm2 & wh2 & \\
\hline Umbilical width & uw & dm1-wh1-wh2 \\
\hline Apertural height & ah & $\mathrm{dm} 1-\mathrm{dm} 2$ \\
\hline Imprint zone & IZ & wh1-ah or wh1-(dm1-dm2) \\
\hline Whorl expansion rate & WER $^{\#}$ & $\begin{array}{l}(\mathrm{dm} 1 / \mathrm{dm} 2)^{2} \\
\text { or: }(\mathrm{dm} 1 /(\mathrm{dm} 1-\mathrm{ah}))^{2}\end{array}$ \\
\hline Umbilical width index & $\mathrm{UWI}^{\#}$ & $\begin{array}{l}\mathrm{uw} / \mathrm{dm} 1 \\
\mathrm{OR}(\mathrm{dm} 1-\mathrm{wh} 1-\mathrm{wh} 2) / \mathrm{dm} 1\end{array}$ \\
\hline Imprint zone rate & $\mathrm{IZR}^{\#}$ & $\begin{array}{l}\text { wh1-ah/wh1 } \\
\text { or }(\text { wh1- }(\mathrm{dm} 1-\mathrm{dm} 2)) / \mathrm{wh} 1\end{array}$ \\
\hline Whorl width index & $\mathrm{WWI}^{\#}$ & ww1/wh1 \\
\hline
\end{tabular}


Figure 1. Outcrop area of the Vasalemma Formation in north-eastern Estonia with reef limestone occurrences in the Vasalemma Formation (Fm) type area.

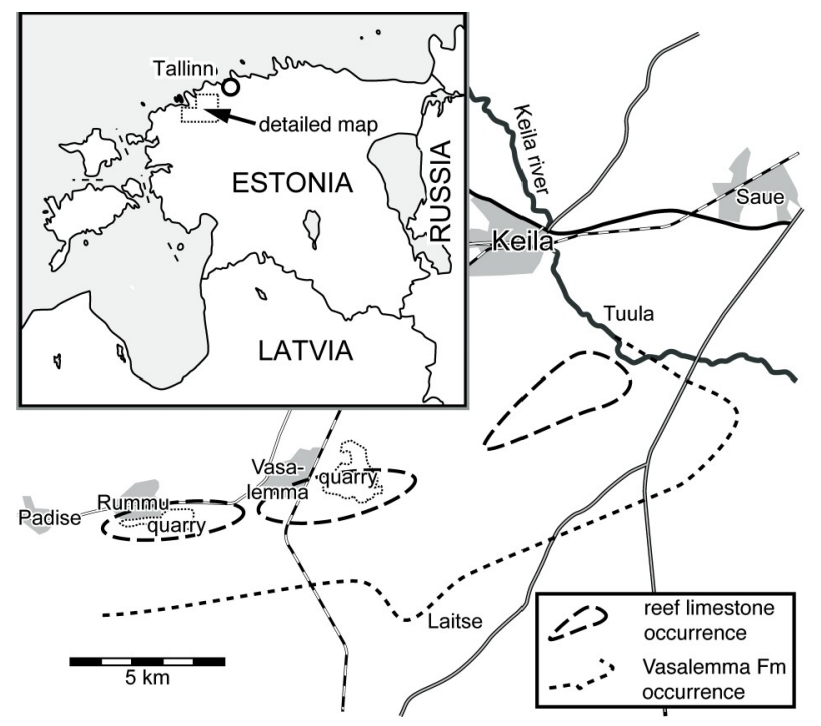

Figure 2. Lithostratigraphy and chronostratigraphic and chemostratigraphic interpretation of the Vasalemma Formation and related units in north-western Estonia (modified from Kröger et al. 2014b). Chemostratigraphy from Ainsaar et al. (2010). 'GICE' sensu lato, refers to the wider stratigraphic range of the Guttenberg-Spechts Ferry carbon isotope excursions see Sell et al. (2015) and discussion in text; KOPE refers to KOPE Carbon Isotope Excursion.

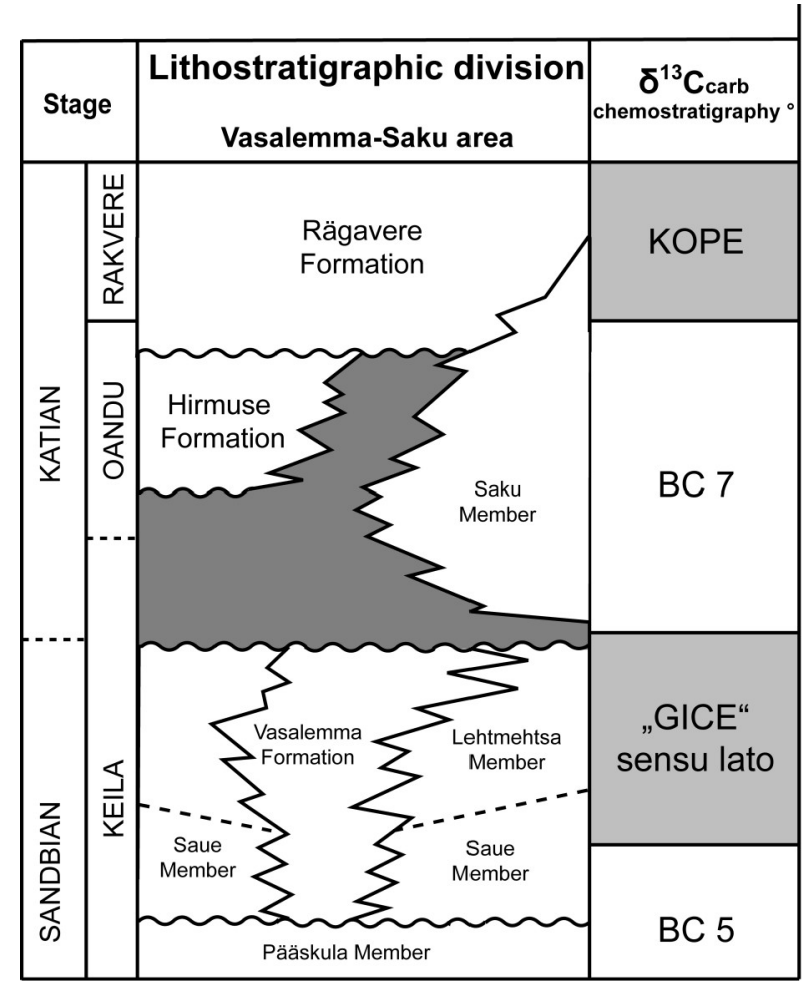


Figure 3. Rummoceras rummuensis gen. et sp. nov., TUG 1709-31, (A) and (B) general views from ventral and dorzal sides, respectively, (C) detail of the siphuncle (lateral section), thick projections visible at the inner side of the connecting rings, (D) transverse cross-section of the shell and the siphuncle. Oriented with apex down.
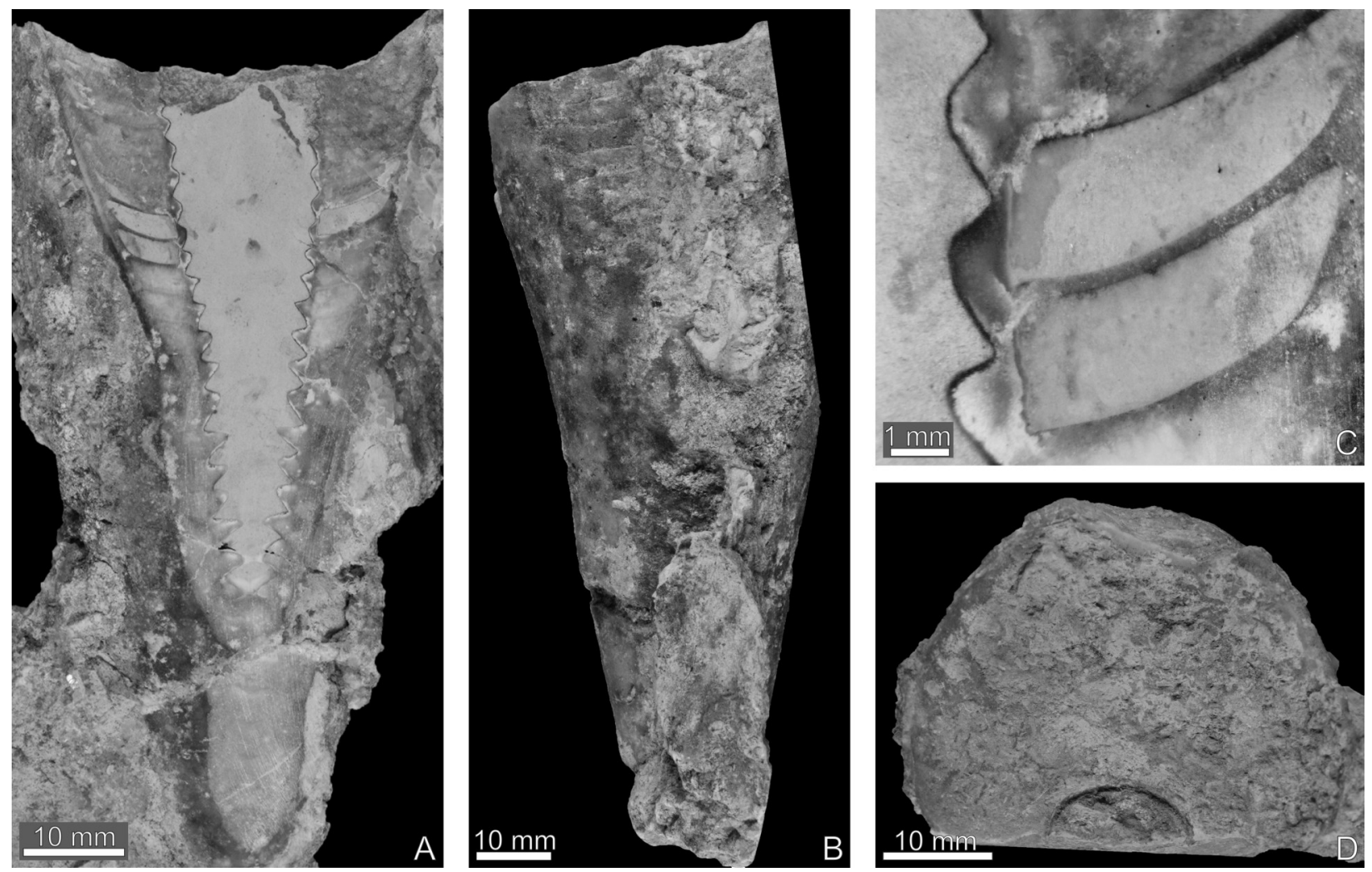
Figure 4. Reconstructions of the structure of the siphuncle in cephalopods from the Vasalemma Formation. Not to scale. A, Beloitoceras cautis sp. nov, TUG 939-54, dotted lines indicate endocameral? deposits; B, Hemibeloitoceras arduum sp.nov., TUG 1612-12; C, Rummoceras rummuensis gen. et sp. nov., TUG 1709-31, dotted lines indicate inner surface of connecting rings; D, Cephalopoda indet, GIT 222-578, note the variability in the shape of the septal necks.
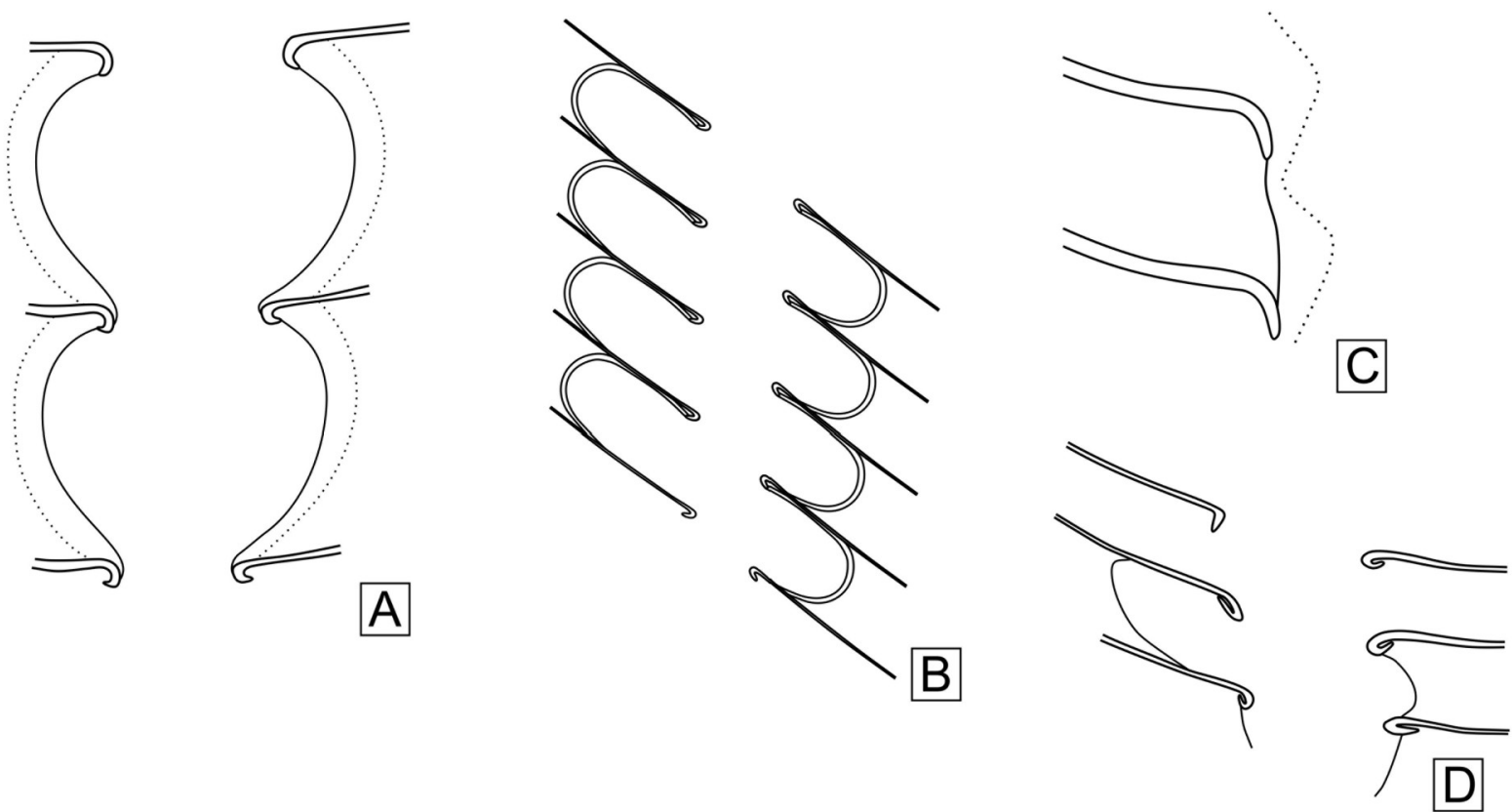

Figure 5. Rummoceras rummuensis, TUG 1709-31, reconstruction of the shape of the shell and siphuncle cross sections (dotted lines indicate reconstructed parts of the shell).

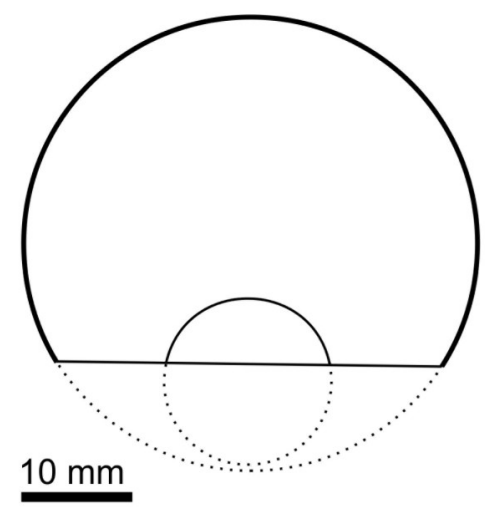


Figure 6. Tarphycerid cephalopods from the Vasalemma Formation. A, B, Trocholites gennadii sp. nov., TUG 93971, (A) general view, (B) shows detail of faint longitudinal and transverse lirae preserved at the ventral adoral side of the shell (apex on base); C, Curtoceras abditus sp. nov., GIT 222-676, reticulate sculpture (longitudinal lirae, transverse striae) preserved at the ventral and adoral side of the shell (apex on base).
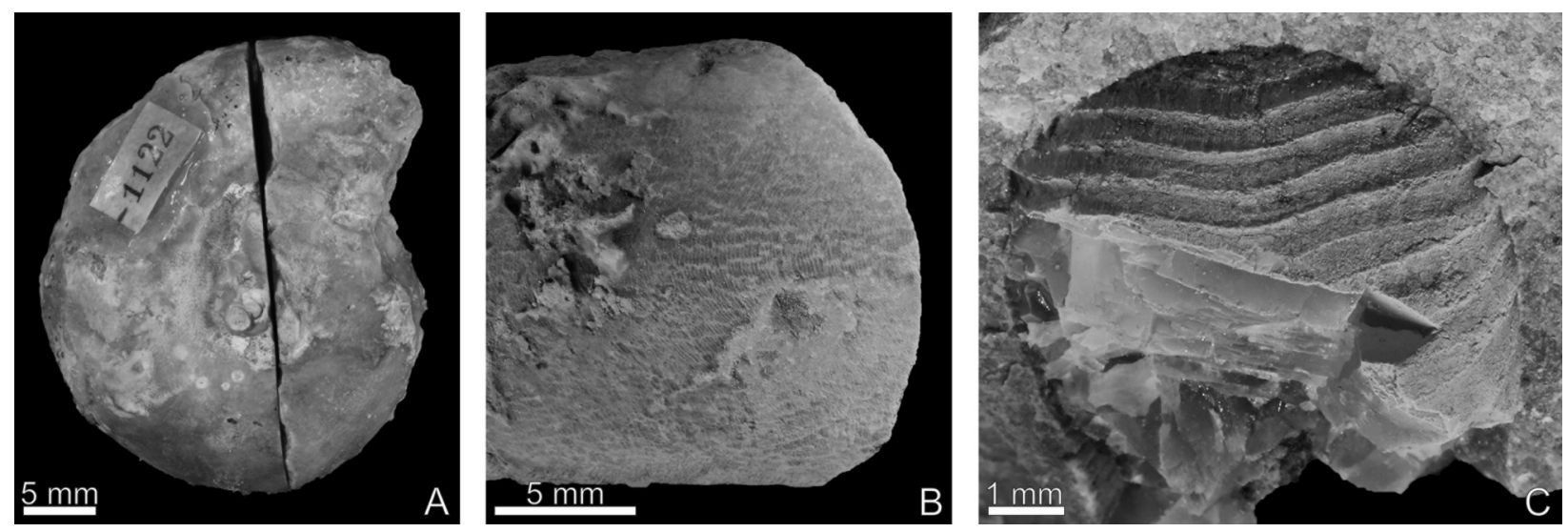
Figure 7. Siphuncular structure in tarphycerid cephalopods from the Vasalemma Formation. Body chamber upwards. A, D, Trocholites gennadii sp.nov., TUG 939-71, median section, (A) general view showing the body chamber and change in height of the latest phragmocone chambers, (D) is detail of the siphuncle with endocameral? deposits at the outer side of the connecting rings; B, E, Discoceras vasalemmense, TUG 939-64, median section, (B) general view, (E) is detail of the apex; C, D. vasalemmense, TUG 939-69, transverse cross-section through the shell (note the change of the cross-section shape from circular to compressed during ontogeny, for discussion see the text above).
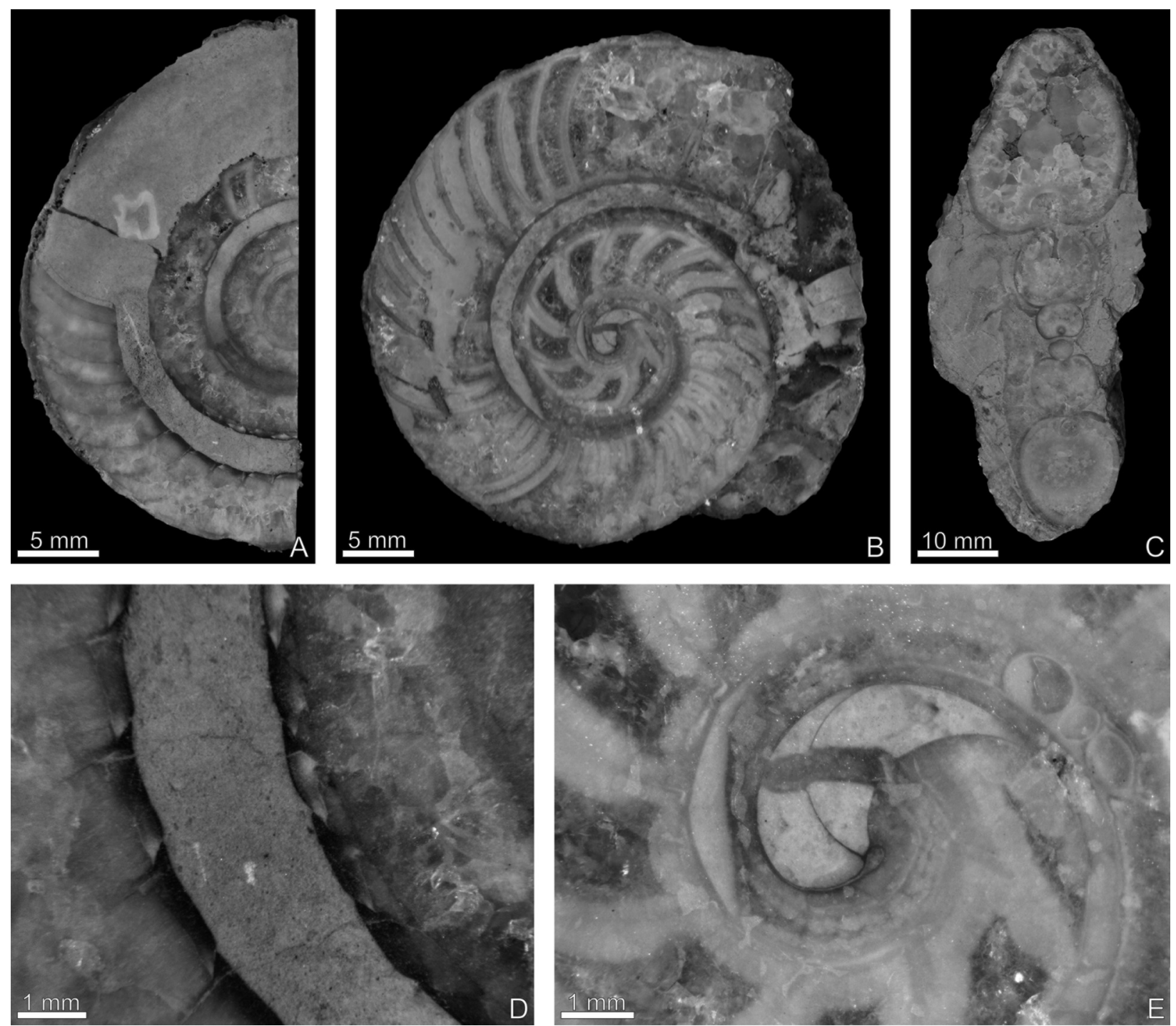
Figure 8. Drawings showing the change of the shell cross-section shape during ontogeny in tarphycerid and barrandeocerid cephalopods from the Vasalemma Formation (see respective discussions in the text above). Dotted lines indicate the assumed original outline of a broken shell. A, B, Discoceras vasalemmense, TUG 939-69 (A) and TUG 939-62 (B); C, D. rarospira, GIT 222-95; D, Trocholites gennadii sp. nov., TUG 939-71; E, Vasalemmoceras tolerabile, GIT 426-133; F, Curtoceras abditus, GIT 222-676.

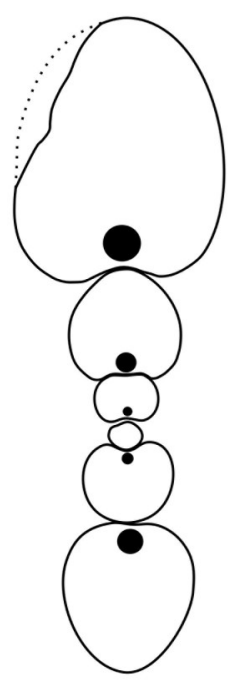

A

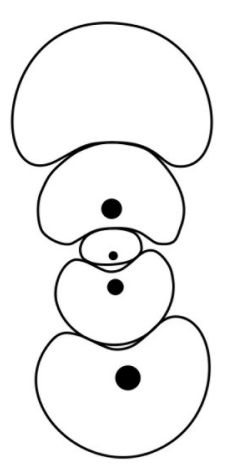

D
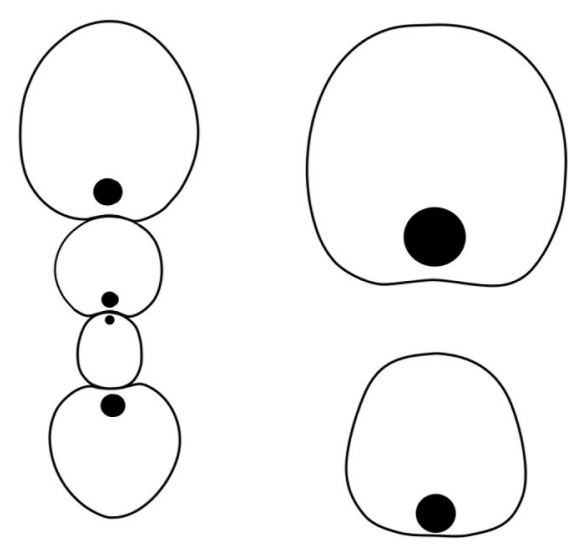

C

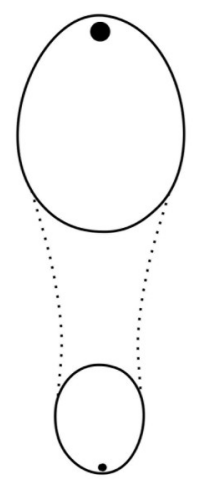

E

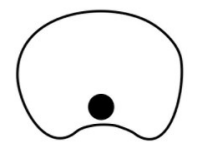

$5 \mathrm{~mm}$

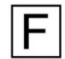


Figure 9. Reconstructions of the structure of the siphuncle in tarphycerid and barrandeocerid cephalopods from the Vasalemma Formation. Dotted lines indicate outer deposits at connecting ring. Not to scale. A, Discoceras vasalemmense, TUG 939-64; B, Trocholites gennadii sp.nov., TUG 939-71; C, Vasalemmoceras tolerabile, GIT 426-129.

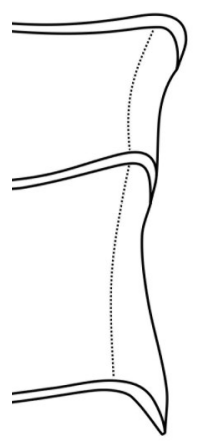

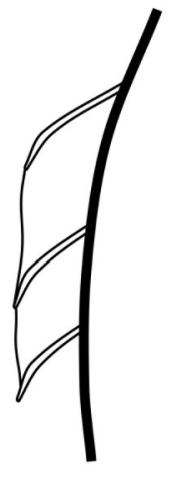

A
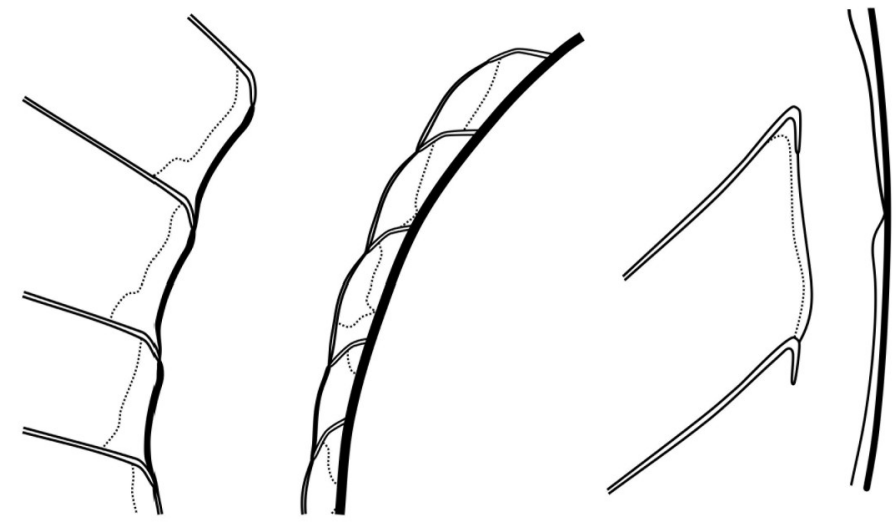

B

Figure 10. Variability in whorl expansion rate (WER) and umbilical width index (UWI) in tarphycerids Trocholites gennadii sp. nov. and Curtoceras abditus sp. nov. from the Vasalemma Formation in comparison with other species of genus Trocholites (see the text above for discussion).
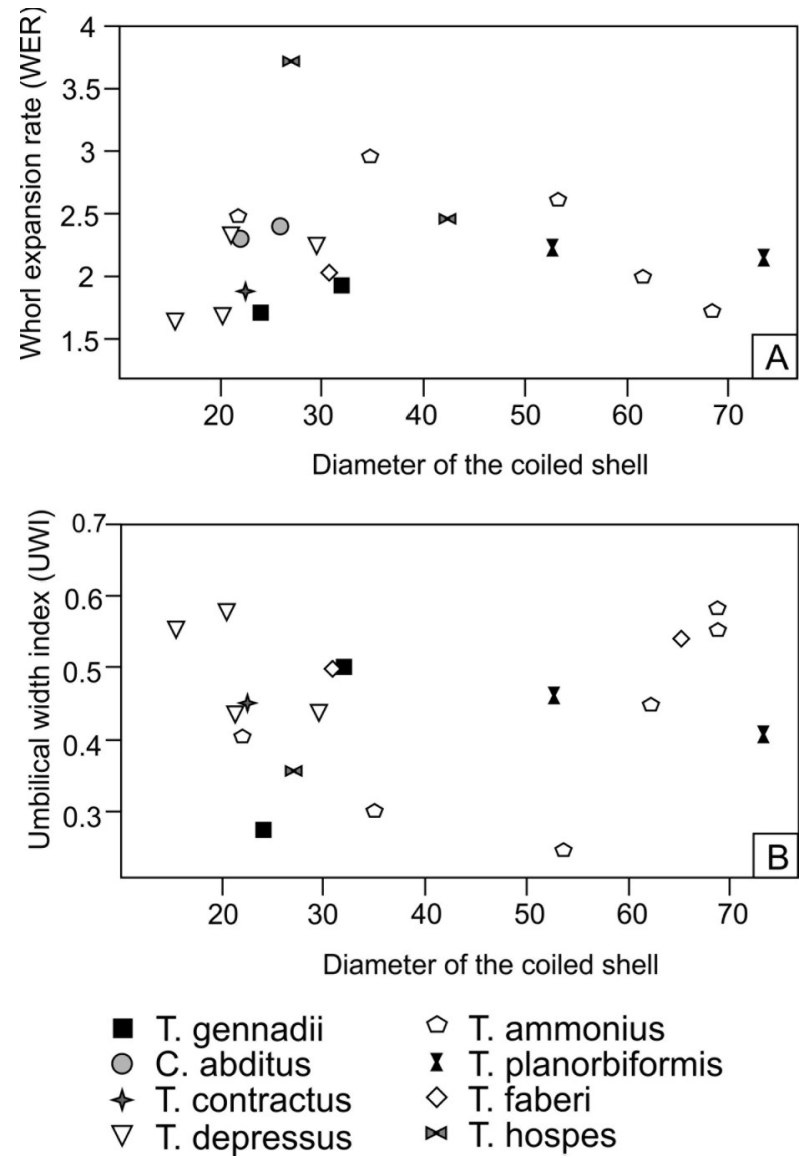

$\checkmark$ T. ammonius

\ T. planorbiformis

$\diamond \mathrm{T}$. faberi

$\bowtie$ T. hospes 
Figure 11. Variability in whorl expansion rate (A), umbilical width index (B) and whorl width index $(\mathbf{C})$ in tarphycerids Discoceras vasalemmense and $D$. rarospira and comparison to the same in $D$. vesenbergense (Balashov, 1953) and D. ievense (Balashov, 1953). Note, that D. rarospira differs from $D$. vasalemmense only in having a slightly higher WER (and flattened ventral side of the shell, see the text above for discussion).
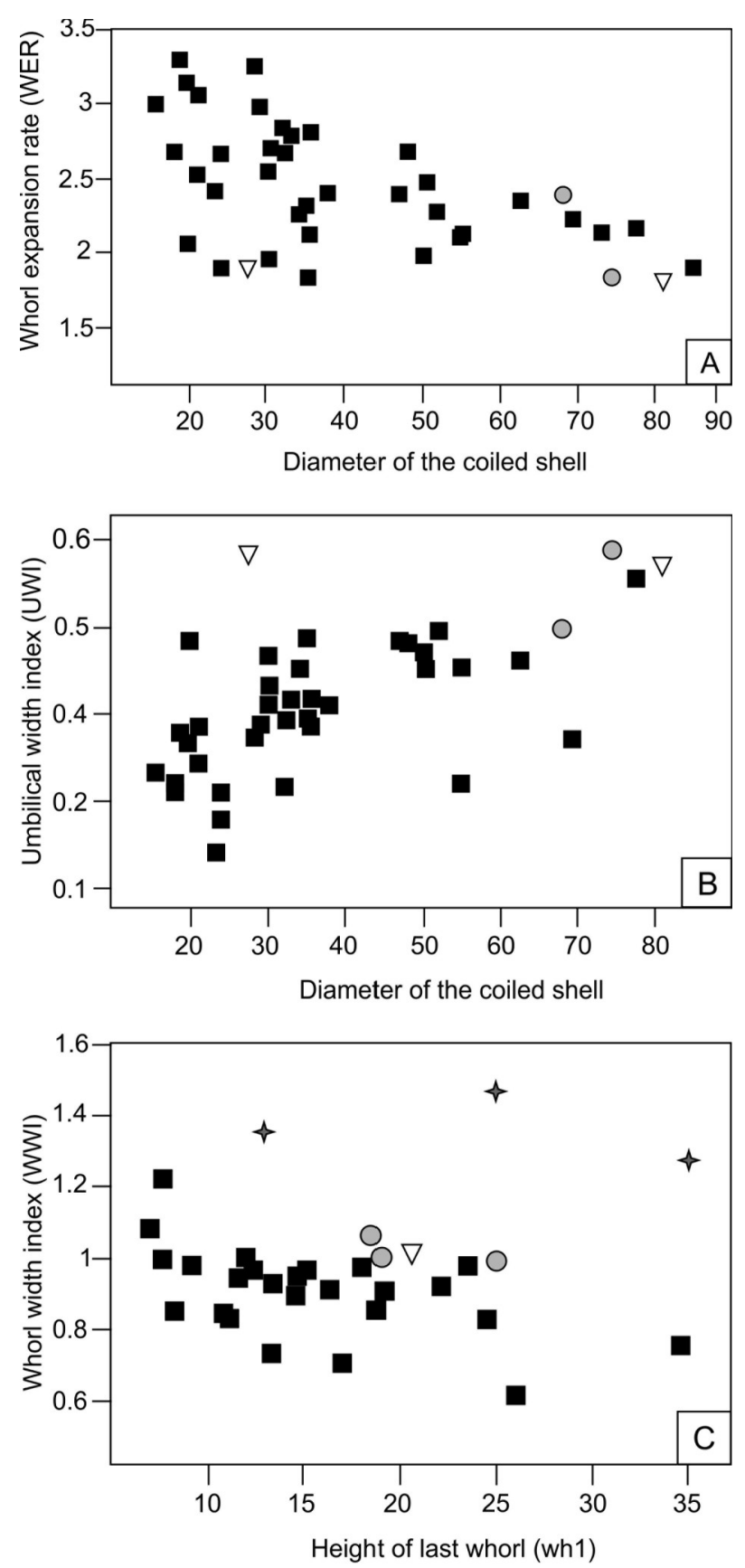

- D. vasalemmense $\&$ D. vesenbergense

D. rarospira $\quad \nabla$ D. ievense 
Figure 12. Discoceras vasalemmense from the Vasalemma Formation. Note the variability in shell sculpture (see the text above). All specimens coated and photographed from lateral side with body chamber upwards unless stated otherwise. (A) NM L 46529 with straight, regularly spaced transverse ribs, (B) and (E) TUG 939-76, specimen with straight, regular ribs and faint longitudinal sculpture (arrows) adapically and frilled transverse ribs adorally, (C) GIT 426-157, small specimen with curved transverse ribs, (D) TUG 1709-15, large specimen with extensive bryozoan overgrowths, (F) GIT 426-148, small specimen with coarse reticulate sculpture.
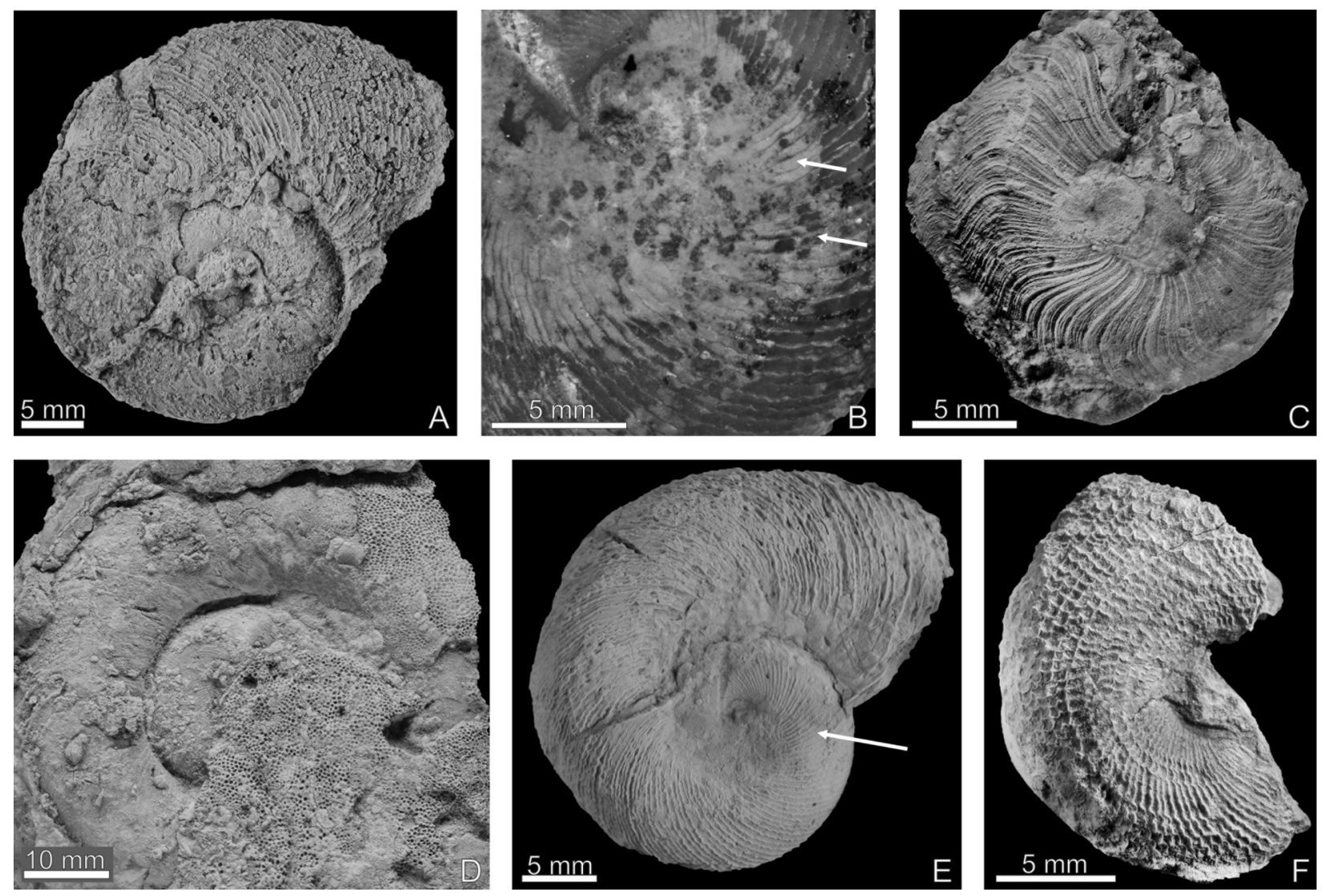
Figure 13. Change of whorl width index (WWI) during ontogeny in coiled cephalopods from the Vasalemma Formation (see the text above). Dotted lines link measurements on the same specimen. A, tarphycerids Discoceras vasalemmense (TUG 939-62, TUG 939-69) and Trocholites gennadii sp. nov. (TUG 939-71), during ontogeny, the WWI decreases in the former species but increases in the latter; B, barrandeocerid Vasalemmoceras tolerabile in which the WWI decreases during ontogeny.
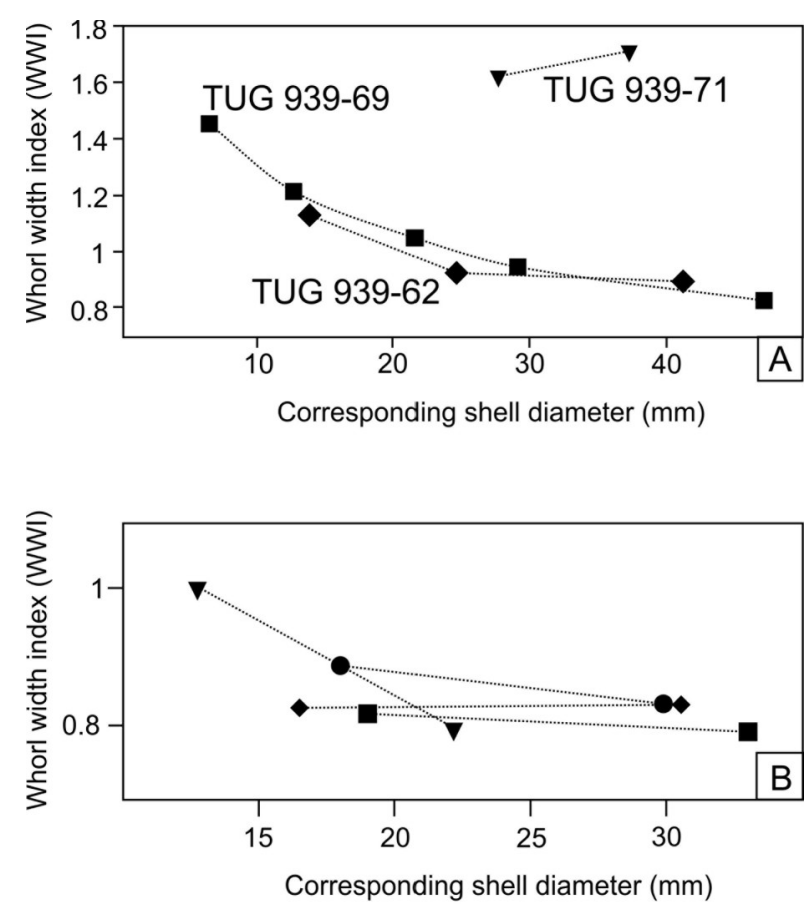

v GIT 426-129a

- GIT 147-4

- GIT 426-133

- GIT 222-91 
Figure 14. Variability in whorl expansion rate (A) and whorl width index (B) in barrandeocerid Vasalemmoceras tolerabile from the Vasalemma Formation. In (A) see also the comparison of WER with Avilionella multicamerata (Ruedemann, 1906) (see the text above for discussion).

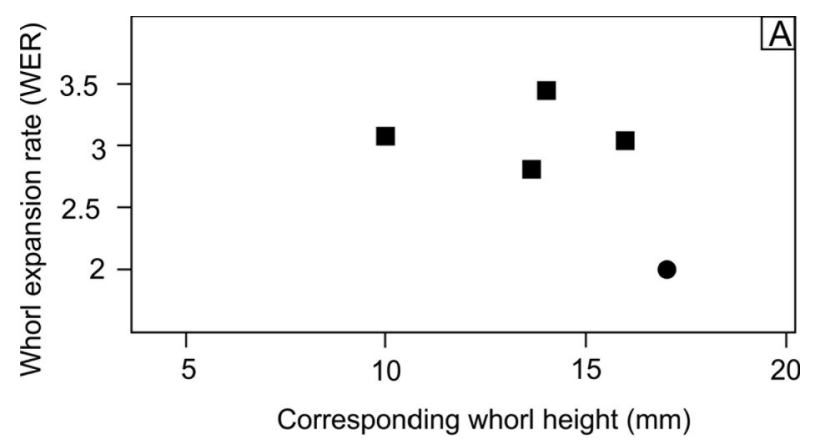

- Vasalemmoceras tolerabile Avilionella multicamerata

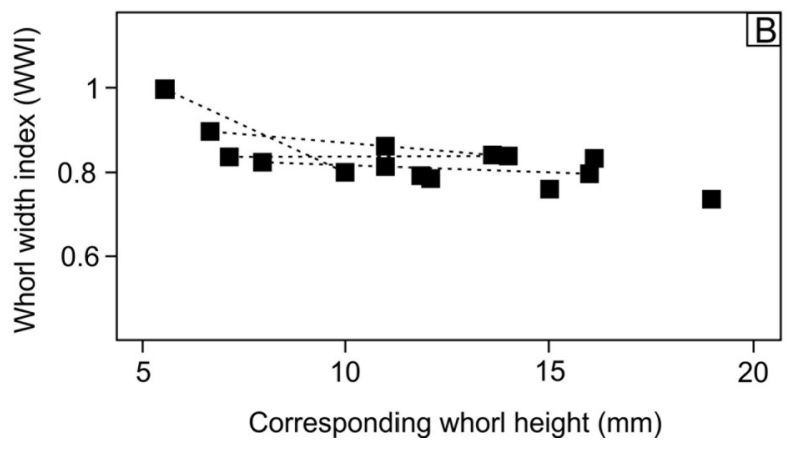


Figure 15. Barrandeocerid Vasalemmoceras tolerabile from the Vasalemma Formation. Specimens photographed from lateral side with body chamber upwards. A, C, GIT 147-4, (A) shell surface with growth-lines (specimen coated), greater angle of expansion of the dorsal side of the shell, (C) median section showing the siphuncle; B, GIT 222-91, shell surface, not coated; D, GIT 426-129, median section showing the siphuncle and apex (partly covered, see the text above); E, F, GIT 426-129, median section showing the siphuncle (E) and detail of the siphuncle (F) with deposits at the outer side of the connecting ring.
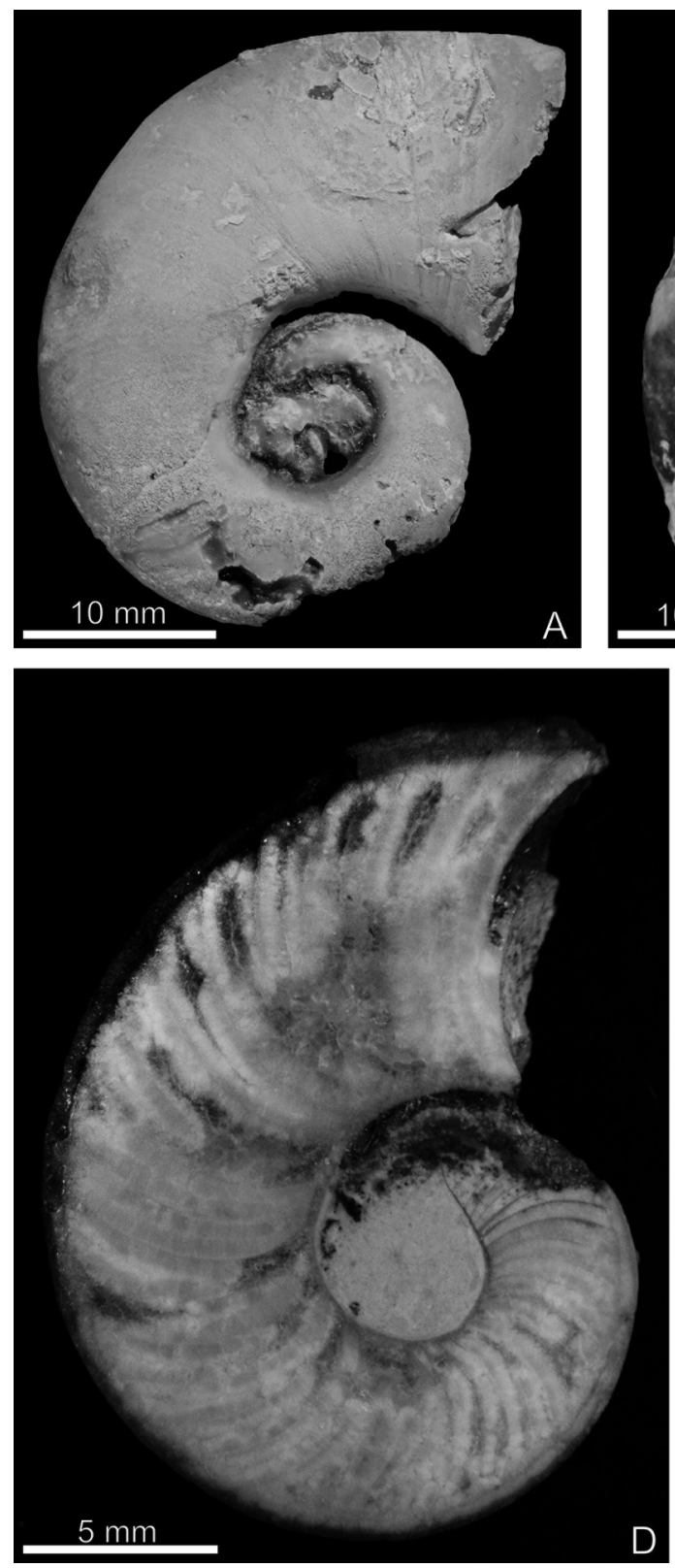
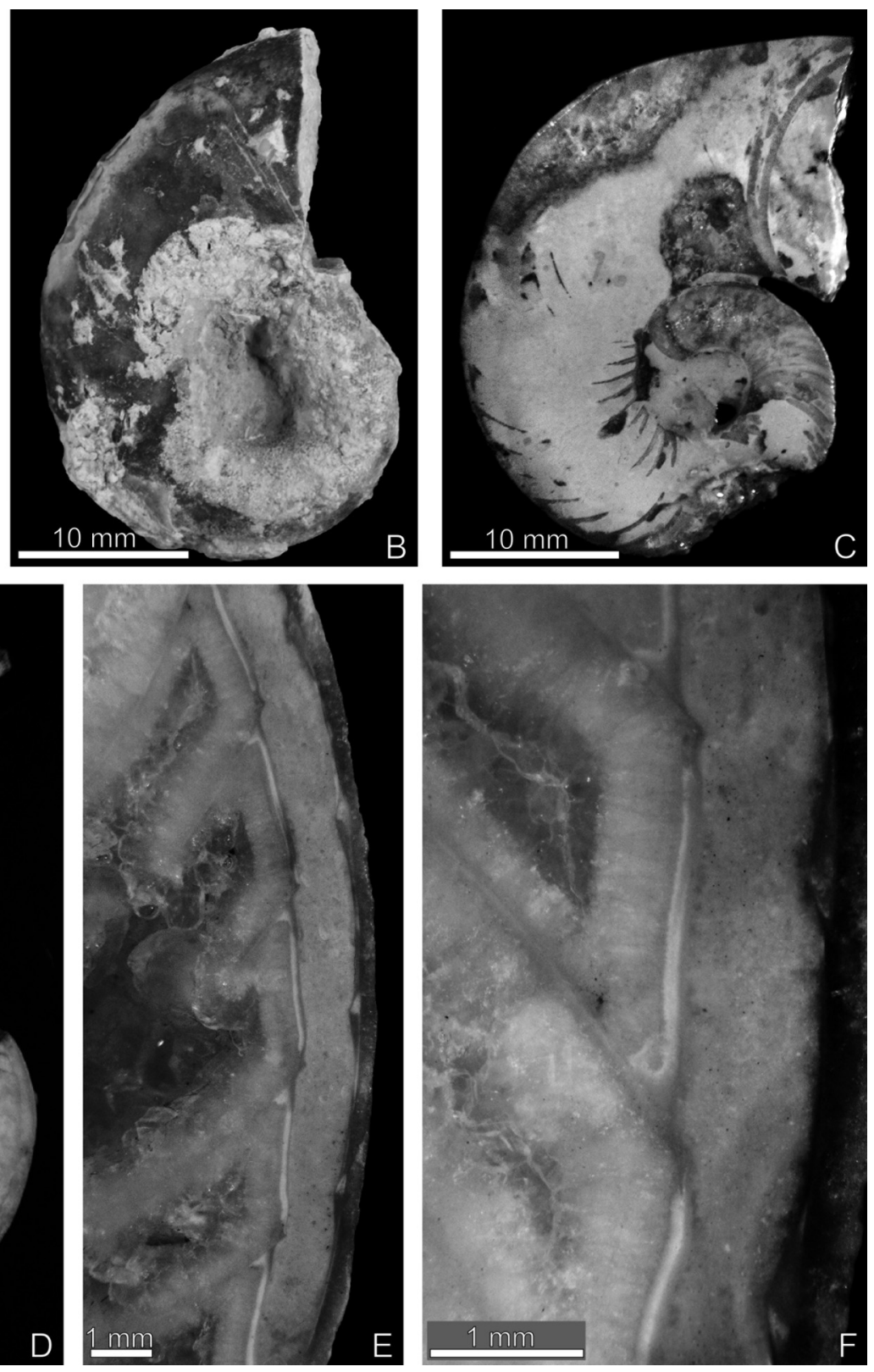
Figure 16. Cephalopods from the Vasalemma Formation. Oriented with apex down. A, Hoeloceras muroni sp. nov., TUG 1709-6, median section showing the siphuncle with heart-shaped connecting rings; B, Cephalopoda indet, GIT 222-578, median section, note the combination of short phragmocone chambers, straight shell, low angle of expansion and a wide siphuncle with cyrtochoanitic septal necks (see the text above); C, Orthonybyoceras isakari sp. nov., TUG 100-8, coated, with shell sculpture of transverse lirae, arrow indicates a repaired shell damage; D, $O$. moisense sp. nov., GIT 222-658, coated, characteristic longitudinal sculpture (lirae).
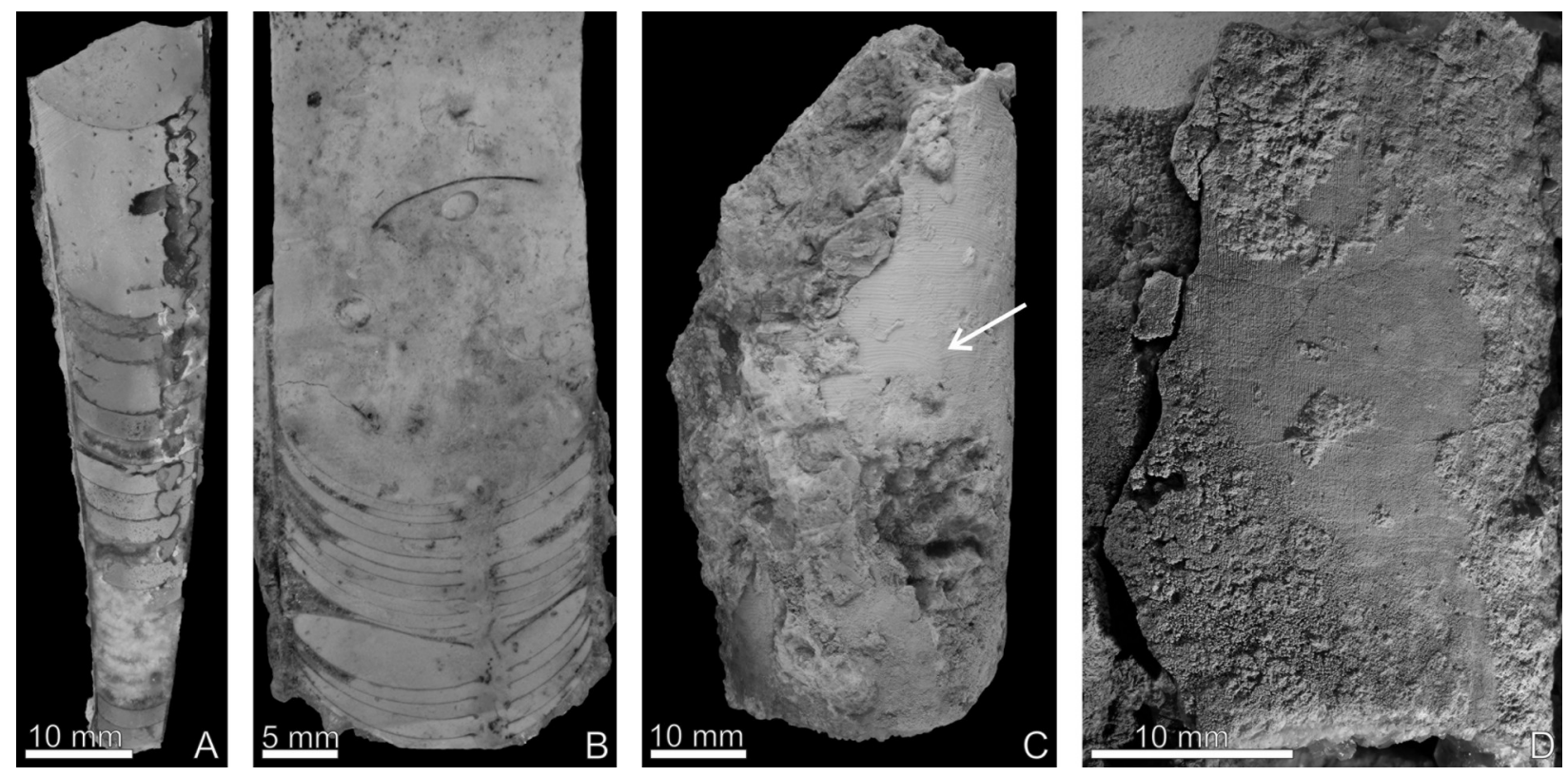
Figure 17. Reconstructions of the structure of the siphuncle in actinocerid cephalopods from the Vasalemma Formation. Note the variability of the septal necks and shape of the connecting rings within the genus Orthonybyoceras. Dotted lines indicate the shape of the annulosiphonate deposits. Not to scale. A, Orthonybyoceras cf. dyeri, TUG 1393-46; B, O. isakari sp. nov., TUG 1709-37; C, O. moisense sp. nov., TUG 939-44; D, Hoeloceras muroni sp. nov., TUG 1709-6; E, O. cf. dyeri, TUG 1709-32.
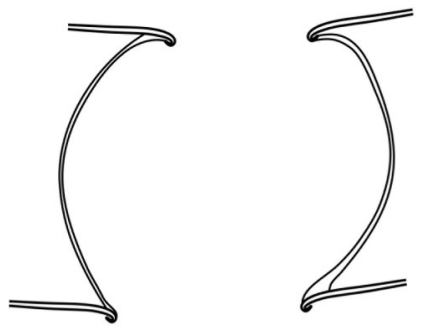

A

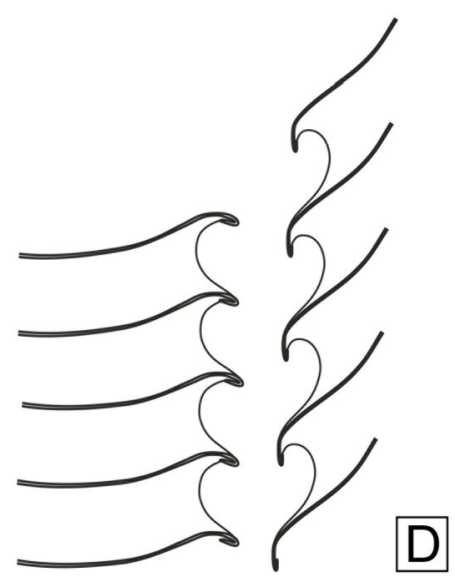

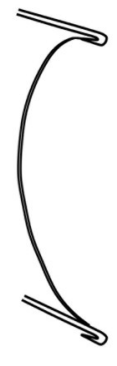
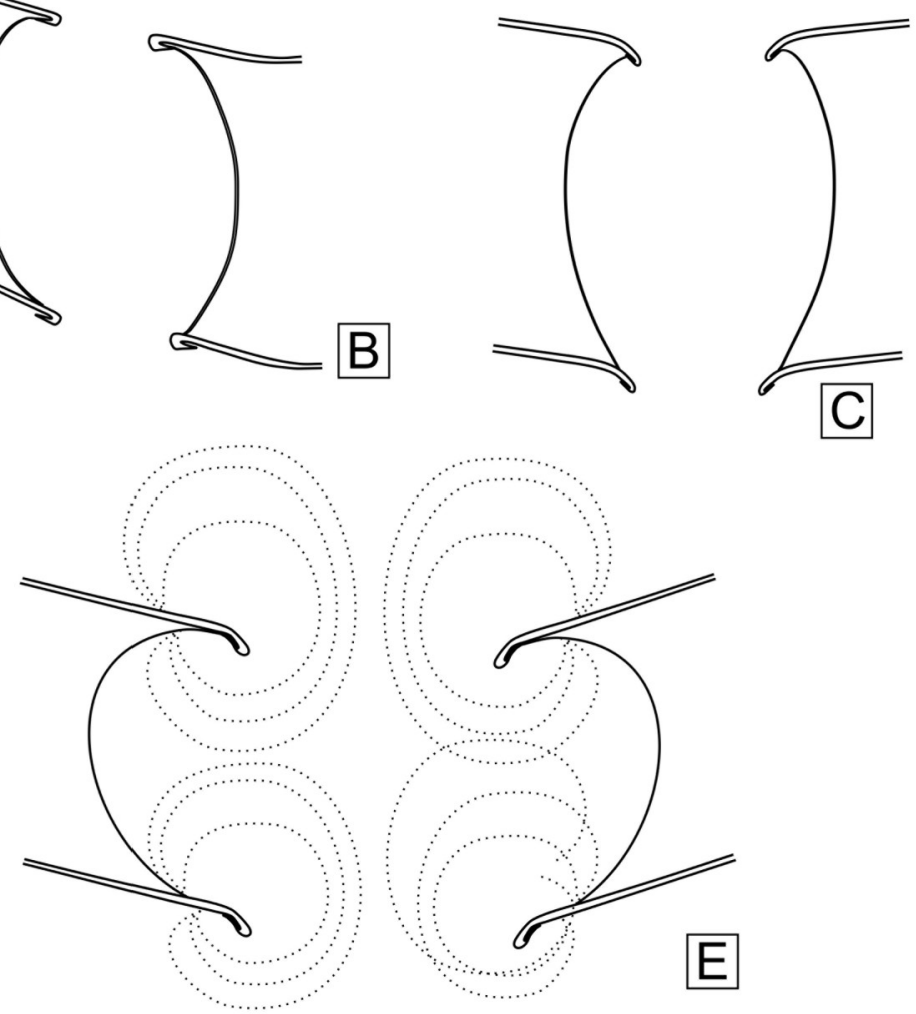
Figure 18. Siphuncular structure in actinocerid Orthonybyoceras. Note the variability in siphuncular structure, annulosiphonate deposits and position of the siphuncle (see text above for discussion). Oriented with apex down. Median section. A, G, $O$. isakari sp. nov., TUG 1393-19, (A) general view, note the broken septa in adoral part of the shell, (G) detail of the siphuncle; B, C, O. cf. dyeri, TUG 1307-1, (B) general view, (C) detail of the siphuncle; D, $O$. cf. dyeri, TUG 1393-46, note the free cyrtochoanitic septal necks; E, I, $O$. cf. dyeri, TUG 939-31, (E) detail of the siphuncle, (I) general view; F, O. moisense sp. nov., TUG 939-44, with small annulosiphonate deposits; H, $O$. isakari sp. nov., TUG 1709-37.
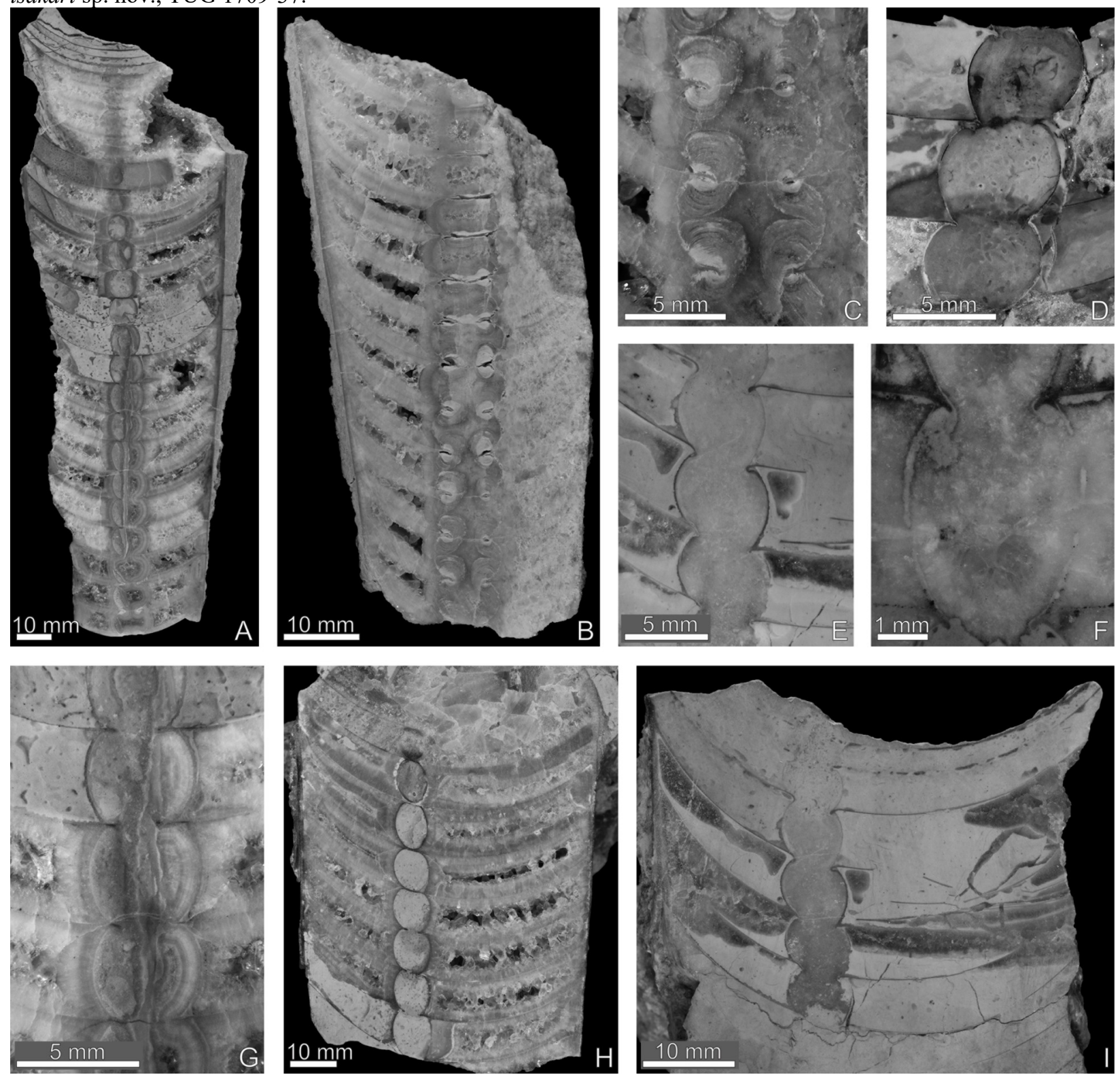
Figure 19. Variability in the angle of expansion (A), relative siphuncular shape (B) and relative siphuncular position $(\mathbf{C})$ in the actinocerid genus Orthonybyoceras from the Vasalemma Formation and comparison with $O$. crebriseptum (Hall, 1847). In (B) note the strong correlation between rss and the respective shell diametre for species $O$. isakari sp. nov. $\left(\mathrm{R}^{2}=0.89\right)$. No significant correlation was observed for $O$. cf. dyeri. See the text above for discussion.
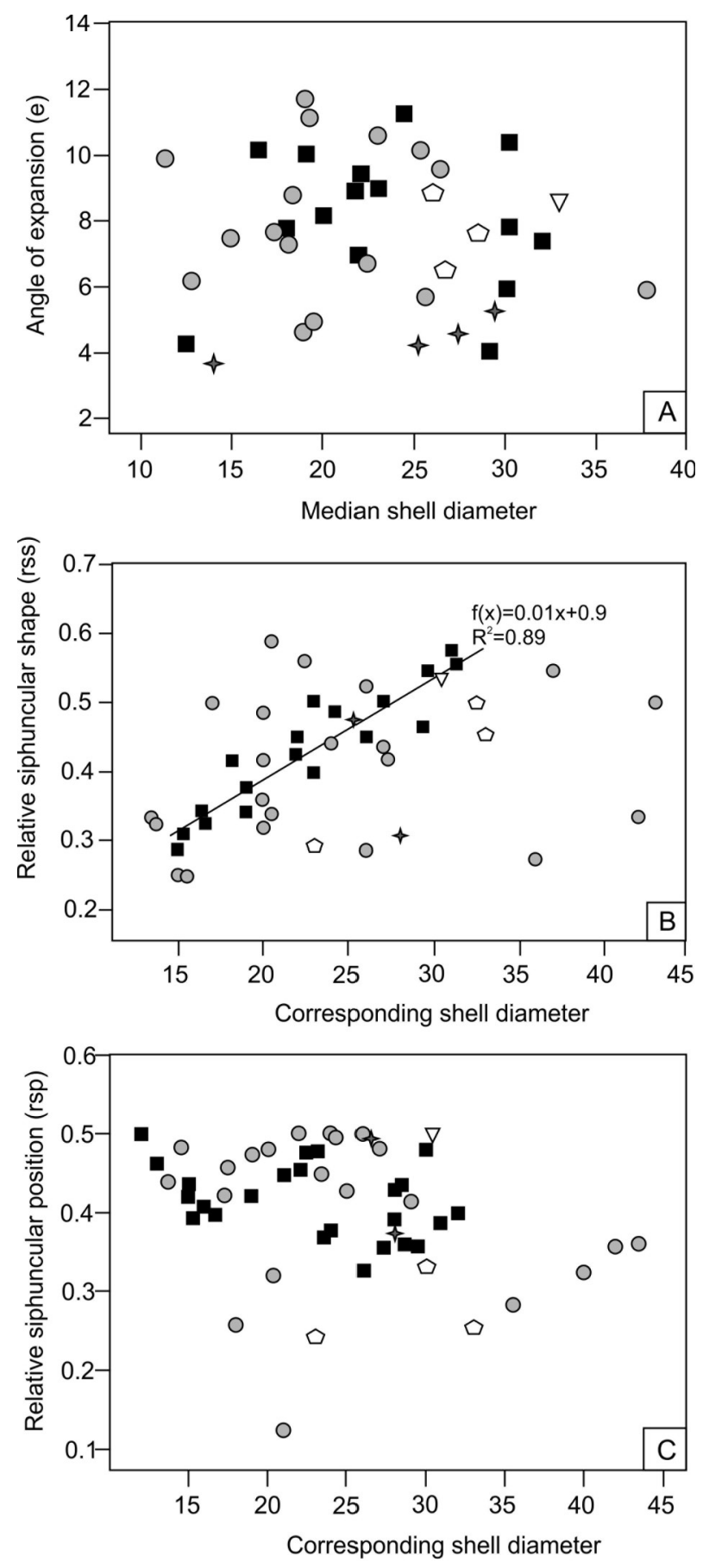

- O. isakari $\nabla$ O. crebriseptum $\bullet \quad$ O. dyeri

O O. cf. dyeri $\&$ O. moisense 
Figure 20. Shell sculpture in orthocerid cephalopods from the Vasalemma Formation. Oriented with apex down. A, D, Isorthoceras cavi sp. nov., TUG 1585-41 (A), TUG 1393-22 (D), transverse, obliquely oriented striae with shallow lobe/sinus and longitudinal lirae; B, I. maris sp. nov., TUG 1393-16, sharp transverse lirae with two lobes and two saddles; C, I. padisense sp. nov., TUG 1585-18b, faint longitudinal lirae, arrow points to a small bryozoan colony; E, F, Pleurorthoceras organi sp. nov., GIT 222-536-2 (E), TUG 1307-27 (F), shell smooth; G, I. vexilli sp. nov., TUG 939-11, arrow points to position of the best preservation of sculpture (transverse, obliquely oriented lirae); H, Ordogeisonoceras tartuensis sp. nov, TUG 939-1065a, sculpture fine transverse lireae, notice bryozoan overgrowth and reparation after shell damage; I, Ordogeisonoceras? sp., TUG 939-8, arrow points to position of the best preservation of sculpture (fine transverse lirae).
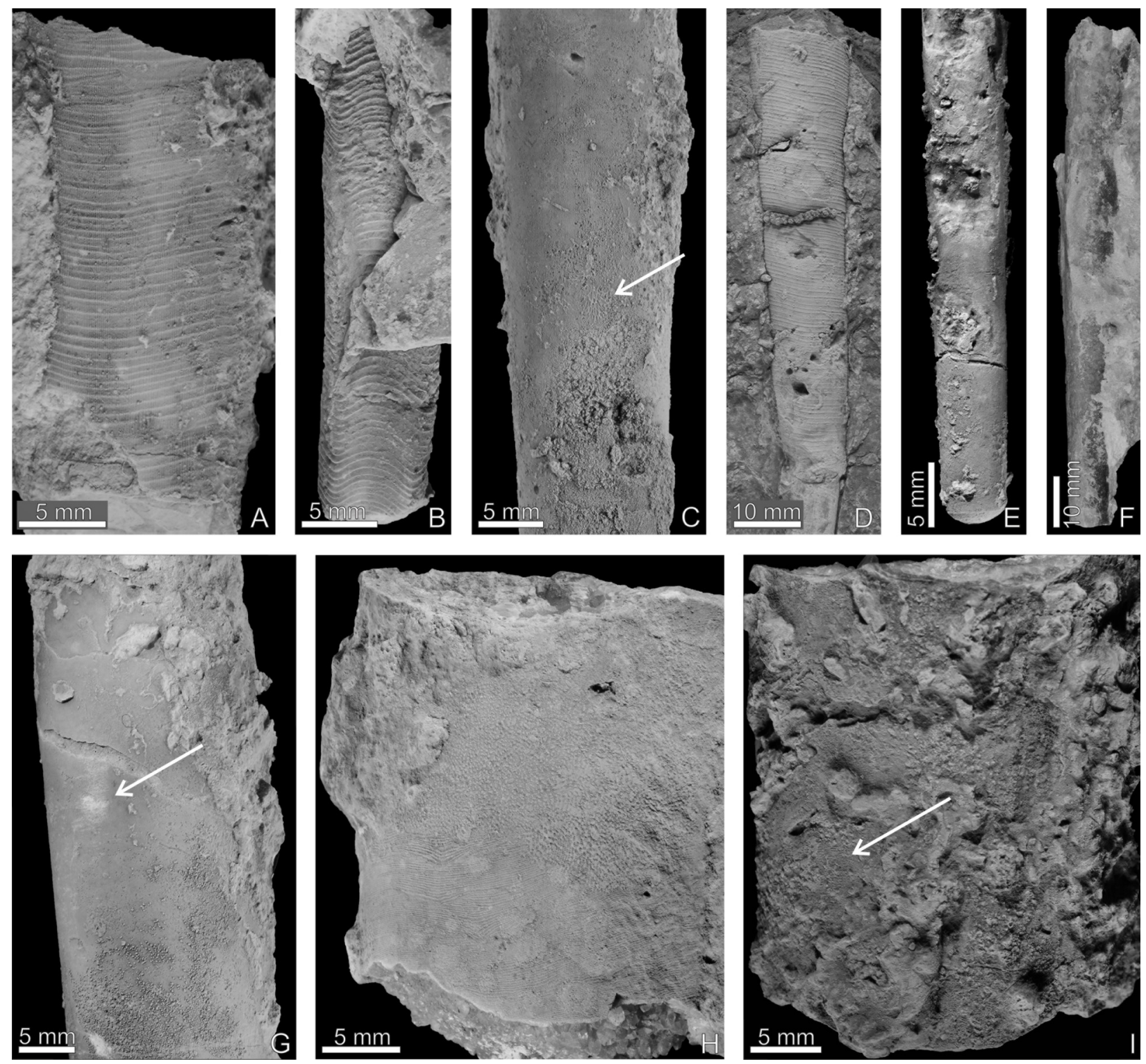
Figure 21. Siphuncular structure in orthocerid cephalopods from the Vasalemma Formation. Oriented with apex down. Median section. A, Ordogeisonoceras? sp., TUG 939-9a; B, Ordogeisonoceras tartuensis sp. nov, TUG 93910; C, H Isorthoceras vexilli sp. nov., (C) TUG 939-33 and (H) TUG 939-11 showing last, shortened phragmocone chambers; D, F I. cavi sp. nov., (D) TUG 1585-41, (F) TUG 1393-45; E, I. maris sp. nov., TUG 1307-26, showing basal portion of the living chamber; G, I. padisense sp. nov., TUG 1709-5; I, Pleurorthoceras organi sp. nov., TUG 939-84.
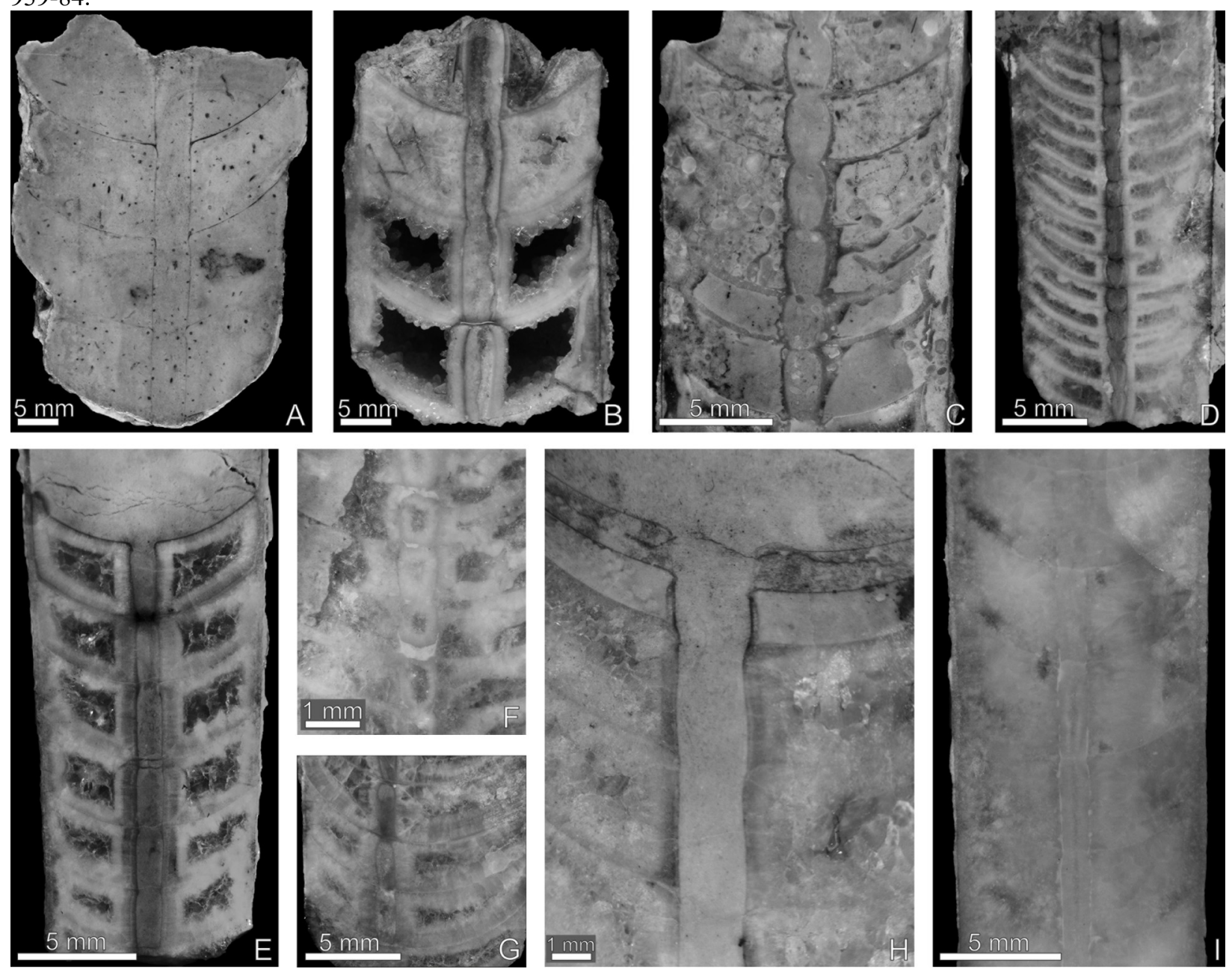
Figure 22. Reconstructions of the structure of the siphuncle in orthocerid cephalopods from the Vasalemma Formation. Not to scale. A, Ordogeisonoceras tartuensis sp. nov, TUG 939-10 with small annulosiphonate deposits (dotted lines); B, Ordogeisonoceras? sp., TUG 939-9a; C, Pleurorthoceras organi sp. nov., TUG 939-84b; C, Isorthoceras vexilli, TUG 939-33; D, Isorthoceras cavi, TUG 1585-41; E, Isorthoceras maris, TUG 1307-26; F, Isorthoceras padisense, TUG 1709-5.
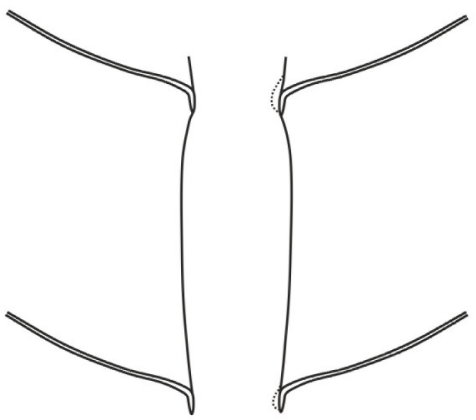

A
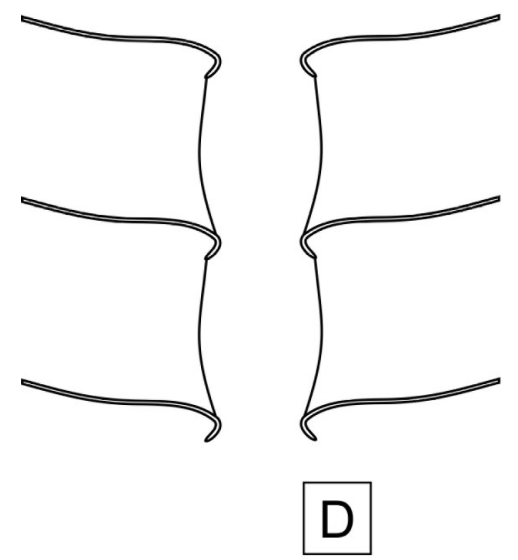
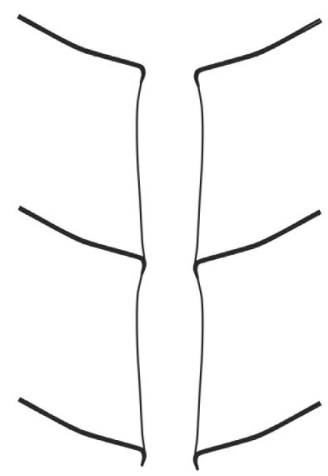

B

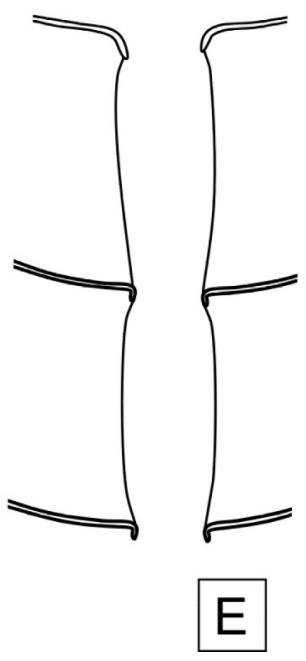

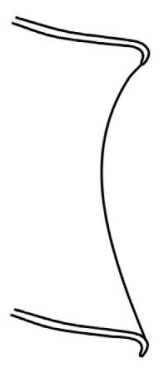

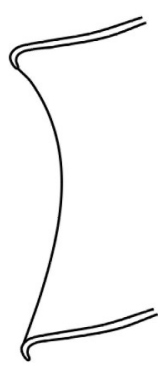

C

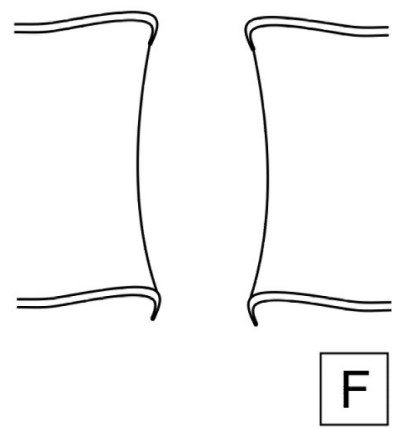


Figure 23. Discosorid Hemibeloitoceras from the Vasalemma Formation. Oriented with apex down. A, F, $H$. arduum sp. nov., TUG 1612-13, (A) lateral view showing shell surface with shallow, irregularly spaced undulations and fine growth lines, (F) lateral section through the siphuncle; B, E, H. arduum sp. nov., TUG 1612-12, median section, (B) general view, (E) detail of the siphuncle; C, Hemibeloitoceras sp., TUG 1307-2b, shell surface shallow undulations and fine growth lines; D, H. arduum sp. nov., TUG 1585-49, large part of the phragmocone with preserved sculpture of undulations and growth lines; G, H. molis sp. nov., GIT 426-164, note the high angle of expansion of the shell.
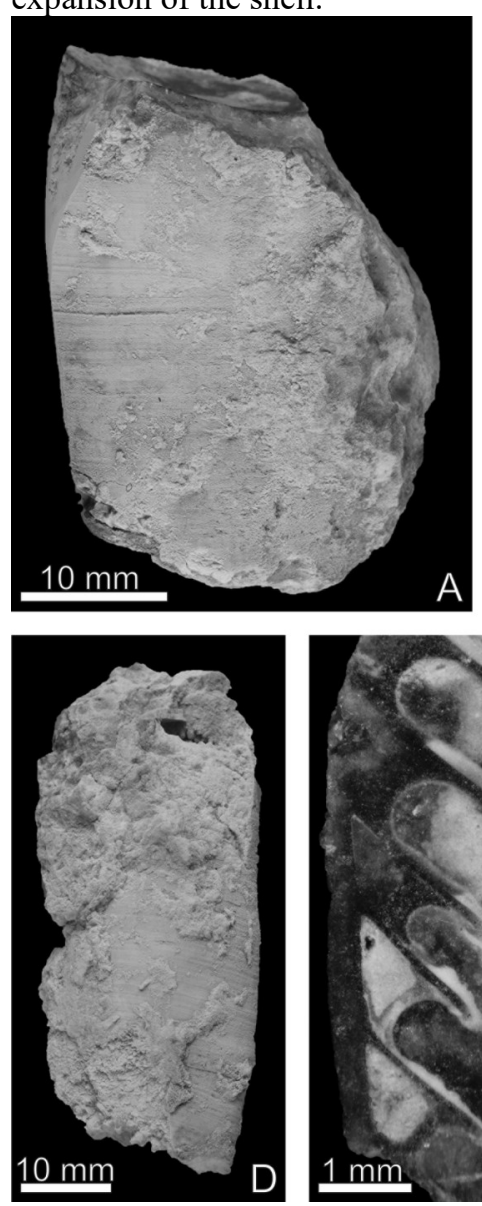
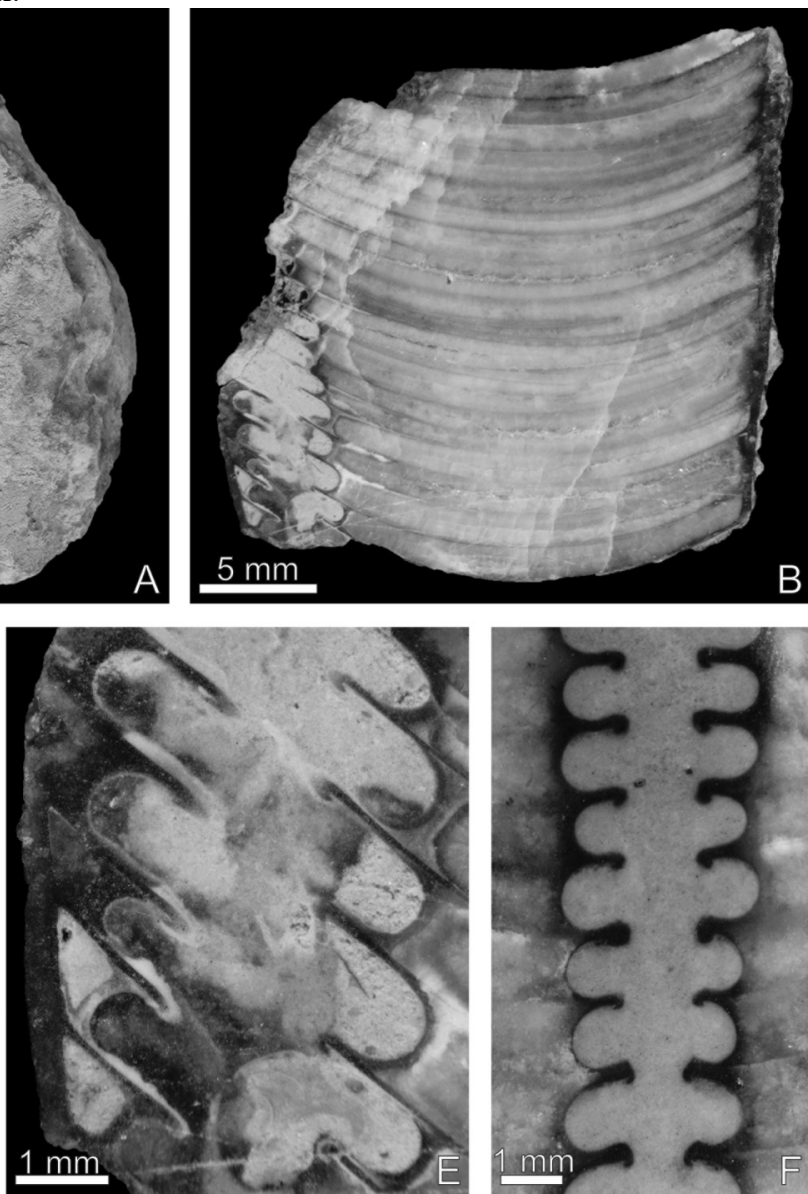

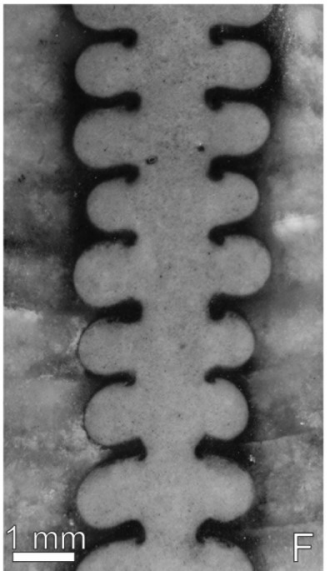

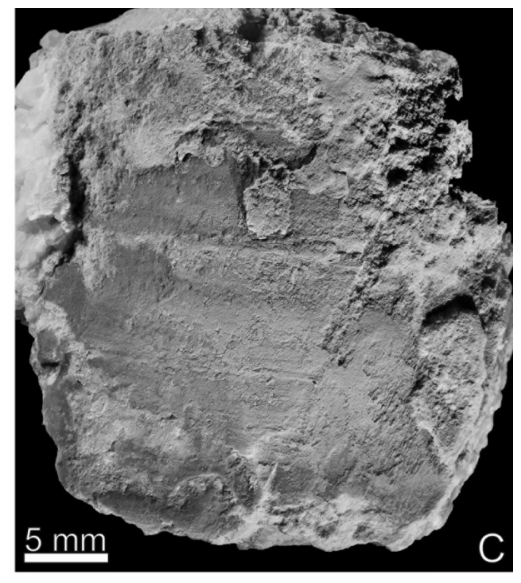

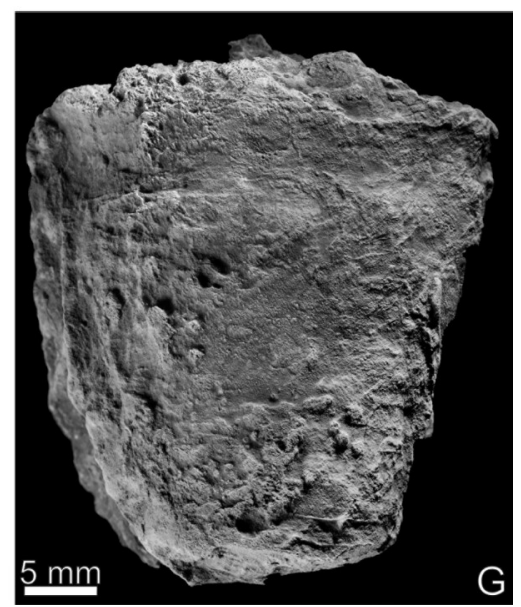


Figure 24. Oncocerid cephalopods from the Vasalemma Formation. Oriented with apex down. A, B, D, Beloitoceras cautis sp. nov., TUG 939-54, shell sculpture (transverse lirae) as shown at the lateral (A) and concave (B) side of the specimen (coated), (D) is detail of the siphuncle (lateral section) with deposits at the outer side of the connecting rings; C, Oncoceratidae indet, GIT 147-5, median section showing the siphuncle and basal portion of the body chamber.
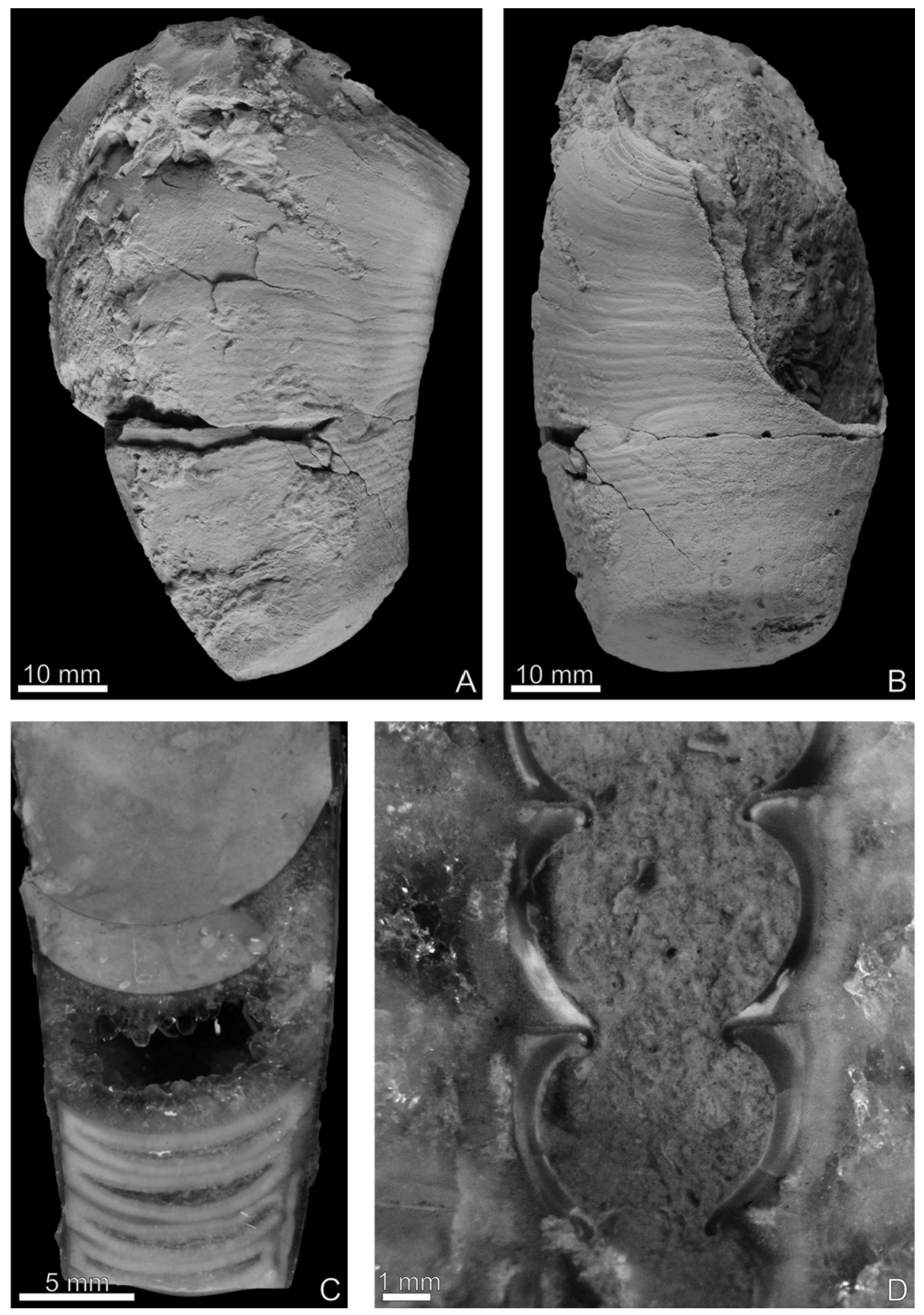
Figure 25. Field photograph of part of a 'cephalopod pocket' in a loose block of reef limestone of the Vasalemma Formation, Keila Regional Stage, Rummu quarry, locality Rummu \#1. Note the chaotic bedding of the fragmented cephalopod shells.

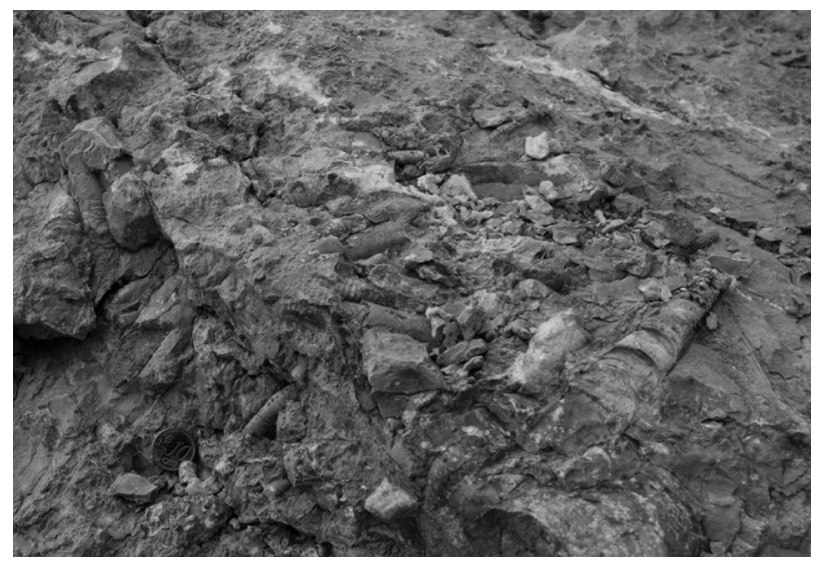

Figure 26. Histogram with sample size of cephalopod orders from the Vasalemma Formation, late Keila Regional Stage, northern Estonia. (Actinocerida: $\mathrm{n}=194$; Orthocerida: $\mathrm{n}=81$; Tarphycerida: $\mathrm{n}=47$; Barrandeocerida: $\mathrm{n}=14$; Discosorida: $n=14$; Oncocerida: $n=4$; Cyrtocerinidia: $n=1$ ).

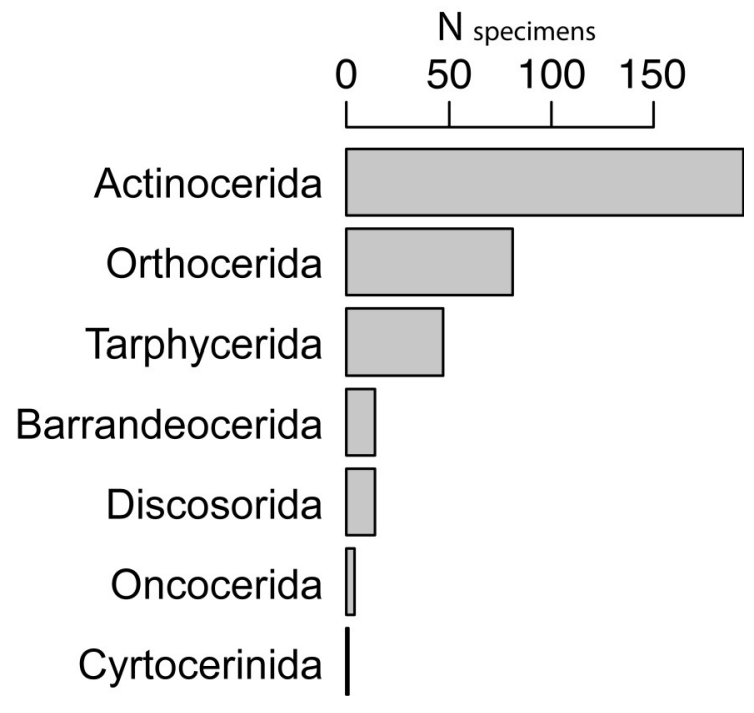


Figure 27. Comparison of selected cephalopod assemblages by relative diversity of cephalopod orders (number of genera per cephalopod order) of selected cephalopod assemblage groups. A, Cluster dendrogram based on BrayCurtis distance matrix and average clustering method; B, Principal Component Analysis (PCA) - plot with Eigenvalues of PC1=34.99, PC2 12.67. BAPP, Baltica-Appalachian cluster; BELB, Baltica-epicontinental Laurentia cluster; Vasalemma, Vasalemma Formation; NOR, Frognerkilen, Mjøsa, and Steinvika formations, Norway (Strand 1934; Sweet 1958); NCH, North Chin, mainly Sheshan Formation; SCH, South China, mainly Pagoda Formation; USEast, Trentonian of New York, USA, and Ontario, Canada; USMid, Illinois, Indiana, Iowa, Kentucky, Minnesota, Wisconsin, USA; USApp, Pennsylvania, Tennessee, Virginia, USA (see Data Supplement 2 for details).
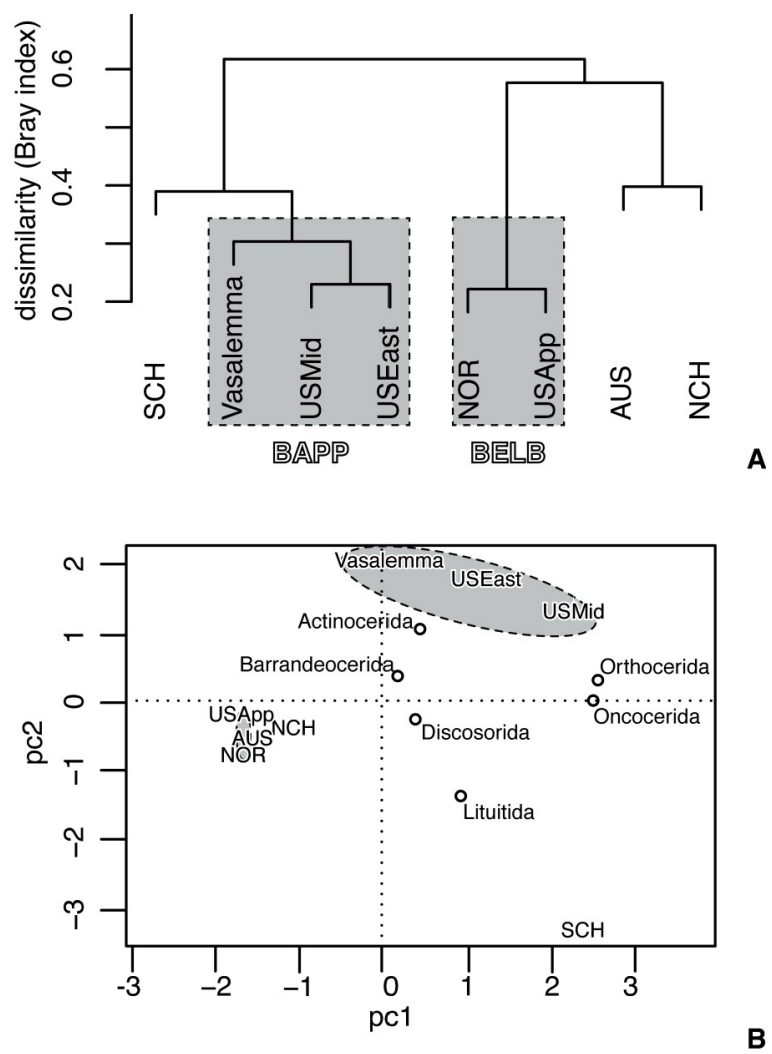
Figure 28. Comparison of selected cephalopod assemblages by genera occurrences. A, Global palaeogeography of late Sandbian Stage after Galls Project from BugPlates (Torsvik 2011); B, Cluster dendrogram based on Raup-Crick distance matrix and average clustering method; C, Principal Component Analysis (PCA) - plot with Eigenvalues of PC1=6.51, PC2 4.34; Vasalemma, Vasalemma Formation; NOR, Frognerkilen, Mjøsa, and Steinvika formations, Norway (Strand 1934; Sweet 1958); NCH, North Chin, mainly Sheshan Formation; SCH, South China, mainly Pagoda Formation; USEast, Trentonian of New York, USA, and Ontario, Canada; USMid, Illinois, Indiana, Iowa, Kentucky, Minnesota, Wisconsin, USA; USApp, Pennsylvania, Tennessee, Virginia, USA (see Data Supplement 2 for details).
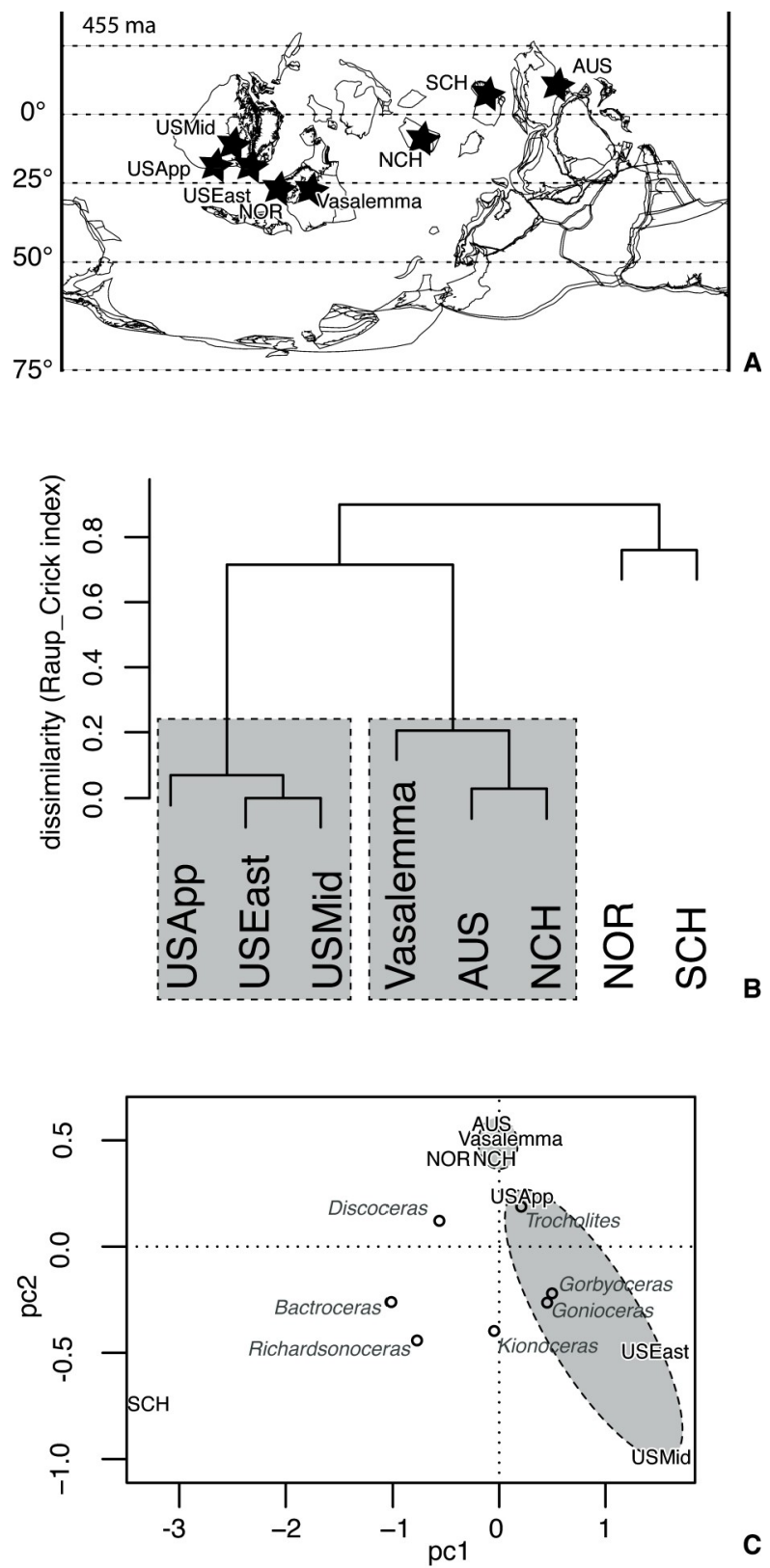

C 
Data Supplement 1. Counts of specimens of the Rummu and Vasalemma localities.

\begin{tabular}{|c|c|c|c|}
\hline Species & Species nr. & Rummu & Vasalemma \\
\hline Barrandeocerid indet & & 0 & 1 \\
\hline Beloitoceras cautis sp. nov. & 1 & 0 & 1 \\
\hline Beloitoceras sp. indet & & 0 & 1 \\
\hline Cephalopoda indet & & 0 & 1 \\
\hline Curtoceras abditus sp. nov. & 2 & 0 & 1 \\
\hline Discoceras rarospira (Eichwald, 1860) & 3 & 1 & 1 \\
\hline Discoceras sp. & & 0 & 3 \\
\hline Discoceras vasalemmense (Balashov, 1953) & 4 & 12 & 24 \\
\hline Hemibeloitoceras arduum sp. nov. & 5 & 3 & 0 \\
\hline Hemibeloitoceras molis sp. nov. & 6 & 1 & 7 \\
\hline Hemibeloitoceras sp. & & 1 & 2 \\
\hline Hoeloceras muroni sp. nov. & 7 & 1 & 0 \\
\hline Isorthoceras cavi sp. nov. & 8 & 3 & 6 \\
\hline Isorthoceras maris sp. nov. & 9 & 0 & 2 \\
\hline Isorthoceras padisense sp. nov. & 10 & 2 & 0 \\
\hline Isorthoceras vexilli sp. nov. & 11 & 1 & 2 \\
\hline Oncoceratidae indet & & 0 & 1 \\
\hline Oncocerida indet & & 0 & 1 \\
\hline Ordogeisonoceras tartuensis sp. nov. & 12 & 0 & 7 \\
\hline Ordogeisonoceras? sp. & & 0 & 2 \\
\hline Orthonybyoceras cf. dyeri (Miller, 1875) & 13 & 25 & 74 \\
\hline Orthonybyoceras isakari sp. nov. & 14 & 25 & 38 \\
\hline Orthonybyoceras moisense sp. nov. & 15 & 1 & 6 \\
\hline Orthonybyoceras sp. & & 0 & 22 \\
\hline Pleurorthoceras organi sp. nov. & 16 & 0 & 5 \\
\hline Rummoceras rummuensis gen. et sp. nov. & 17 & 1 & 0 \\
\hline Striatocycloceras undulostriatum Kröger \& Isakar, 2006 & 18 & 18 & 33 \\
\hline Trocholites gennadii sp. nov. & 19 & 0 & 2 \\
\hline Vasalemmoceras tolerabile Stumbur, 1962 & 20 & 1 & 12 \\
\hline
\end{tabular}

Data Supplement 2. List of all specimens used in this study.

\begin{tabular}{|l|l|l|}
\hline Species & $\begin{array}{l}\text { Specimen } \\
\text { number }\end{array}$ & Locality \\
\hline DISCOCERAS VASALEMMENSE (BALASHOV, 1953) & TUG 939-61 & Vasalemma \\
\hline DISCOCERAS VASALEMMENSE (BALASHOV, 1953) & TUG 939-76 & Vasalemma \\
\hline DISCOCERAS VASALEMMENSE (BALASHOV, 1953) & TUG 939-64 & Vasalemma \\
\hline
\end{tabular}




\begin{tabular}{|c|c|c|}
\hline DISCOCERAS VASALEMMENSE (BALASHOV, 1953) & TUG 939-63 & Vasalemma \\
\hline DISCOCERAS VASALEMMENSE (BALASHOV, 1953) & TUG 939-69 & Vasalemma \\
\hline DISCOCERAS VASALEMMENSE (BALASHOV, 1953) & TUG 939-70 & Vasalemma \\
\hline DISCOCERAS VASALEMMENSE (BALASHOV, 1953) & TUG 47-860 & \\
\hline DISCOCERAS VASALEMMENSE (BALASHOV, 1953) & TUG 1307-30 & Vasalemma Quarry \\
\hline DISCOCERAS VASALEMMENSE (BALASHOV, 1953) & NM L 46527 & Rummu Quarry \\
\hline DISCOCERAS VASALEMMENSE (BALASHOV, 1953) & NM L 46528 & Rummu Quarry \\
\hline DISCOCERAS VASALEMMENSE (BALASHOV, 1953) & NM L 46529 & Rummu Quarry \\
\hline DISCOCERAS VASALEMMENSE (BALASHOV, 1953) & NM L 46530 & Rummu Quarry \\
\hline DISCOCERAS VASALEMMENSE (BALASHOV, 1953) & NM L 46531 & Rummu Quarry \\
\hline DISCOCERAS VASALEMMENSE (BALASHOV, 1953) & NM L 46532 & Rummu Quarry \\
\hline DISCOCERAS VASALEMMENSE (BALASHOV, 1953) & TUG 1644-95 & Vasalemma Quarry \\
\hline DISCOCERAS VASALEMMENSE (BALASHOV, 1953) & TUG 1644-97 & \\
\hline DISCOCERAS VASALEMMENSE (BALASHOV, 1953) & TUG 1393-42 & \\
\hline DISCOCERAS VASALEMMENSE (BALASHOV, 1953) & TUG 1709-15 & Rummu Quarry, Rummu 1 \\
\hline DISCOCERAS VASALEMMENSE (BALASHOV, 1953) & TUG 1585-39 & Rummu Quarry, Rummu 1 \\
\hline DISCOCERAS VASALEMMENSE (BALASHOV, 1953) & TUG 1393-43 & Vasalemma Quarry, reef 25 \\
\hline DISCOCERAS VASALEMMENSE (BALASHOV, 1953) & TUG 1393-44 & Vasalemma Quarry, reef 26 \\
\hline DISCOCERAS VASALEMMENSE (BALASHOV, 1953) & TUG 1585-33 & Rummu Quarry, Rummu 1 \\
\hline DISCOCERAS VASALEMMENSE (BALASHOV, 1953) & TUG 1585-61 & Rummu Quarry, Rummu 1 \\
\hline DISCOCERAS VASALEMMENSE (BALASHOV, 1953) & TUG 1585-36 & Rummu Quarry, Rummu 1 \\
\hline DISCOCERAS VASALEMMENSE (BALASHOV, 1953) & TUG 1585-40 & Rummu Quarry, Rummu 1 \\
\hline DISCOCERAS VASALEMMENSE (BALASHOV, 1953) & GIT 222-668 & Vasalemma \\
\hline DISCOCERAS VASALEMMENSE (BALASHOV, 1953) & GIT 222-536-1 & Vasalemma \\
\hline DISCOCERAS VASALEMMENSE (BALASHOV, 1953) & GIT 222-93 & Vasalemma Quarry \\
\hline DISCOCERAS VASALEMMENSE (BALASHOV, 1953) & GIT 222-94 & Vasalemma Quarry \\
\hline DISCOCERAS VASALEMMENSE (BALASHOV, 1953) & GIT 222-92 & Vasalemma Quarry \\
\hline DISCOCERAS VASALEMMENSE (BALASHOV, 1953) & GIT 222-543 & Vasalemma Quarry \\
\hline DISCOCERAS VASALEMMENSE (BALASHOV, 1953) & GIT 222-544 & Vasalemma Quarry \\
\hline DISCOCERAS VASALEMMENSE (BALASHOV, 1953) & GIT 222-545-2 & Vasalemma Quarry \\
\hline DISCOCERAS VASALEMMENSE (BALASHOV, 1953) & GIT 222-98 & Vasalemma Quarry \\
\hline DISCOCERAS VASALEMMENSE (BALASHOV, 1953) & GIT 222-90 & Vasalemma Quarry \\
\hline DISCOCERAS VASALEMMENSE (BALASHOV, 1953) & GIT 222-96 & Vasalemma Quarry \\
\hline DISCOCERAS VASALEMMENSE (BALASHOV, 1953) & GIT 222-439 & Vasalemma Quarry \\
\hline DISCOCERAS VASALEMMENSE (BALASHOV, 1953) & GIT 222-589 & Vasalemma Quarry \\
\hline DISCOCERAS VASALEMMENSE (BALASHOV, 1953) & GIT 222-590 & Vasalemma Quarry \\
\hline \multicolumn{3}{|l|}{ total 39 specimens } \\
\hline DISCOCERAS RAROSPIRA (EICHWALD, 1860) & GIT 222-95 & Vasalemma Quarry \\
\hline DISCOCERAS RAROSPIRA (EICHWALD, 1860) & TUG 1585-34 & Rummu Quarry, Rummu 1 \\
\hline \multicolumn{3}{|l|}{ total 2 specimens } \\
\hline DISCOCERAS sp. & GIT 222-571 & Vasalemma Quarry \\
\hline DISCOCERAS sp. & GIT 222-677-1 & Vasalemma \\
\hline DISCOCERAS sp. & GIT 222-677-2 & Vasalemma \\
\hline
\end{tabular}




\begin{tabular}{|c|c|c|}
\hline \multicolumn{3}{|l|}{ total 3 specimens } \\
\hline TROCHOLITES GENNADII sp. nov. & TUG 939-71 & Vasalemma \\
\hline TROCHOLITES GENNADII sp. nov. & GIT 222-669 & Vasalemma \\
\hline \multicolumn{3}{|l|}{ total 2 specimens } \\
\hline CURTOCERAS ABDITUS sp. nov. & GIT 222-676 & Vasalemma \\
\hline \multicolumn{3}{|l|}{ total 1 specimen } \\
\hline VASALEMMOCERAS TOLERABILE STUMBUR, 1962 & GIT 426-134 & Vasalemma \\
\hline VASALEMMOCERAS TOLERABILE STUMBUR, 1962 & GIT 426-132 & Vasalemma \\
\hline VASALEMMOCERAS TOLERABILE STUMBUR, 1962 & GIT 426-130 & Vasalemma \\
\hline VASALEMMOCERAS TOLERABILE STUMBUR, 1962 & GIT 426-133 & Vasalemma \\
\hline VASALEMMOCERAS TOLERABILE STUMBUR, 1962 & GIT 426-135 & Vasalemma \\
\hline VASALEMMOCERAS TOLERABILE STUMBUR, 1962 & GIT 426-129a & Vasalemma \\
\hline VASALEMMOCERAS TOLERABILE STUMBUR, 1962 & GIT 426-129b & Vasalemma \\
\hline VASALEMMOCERAS TOLERABILE STUMBUR, 1962 & GIT 426-131 & Vasalemma \\
\hline VASALEMMOCERAS TOLERABILE STUMBUR, 1962 & TUG 1585-20a & Rummu Quarry, Rummu 1 \\
\hline VASALEMMOCERAS TOLERABILE STUMBUR, 1962 & GIT 147-4 & Vasalemma \\
\hline VASALEMMOCERAS TOLERABILE STUMBUR, 1962 & GIT 222-91 & Vasalemma Quarry \\
\hline VASALEMMOCERAS TOLERABILE STUMBUR, 1962 & GIT 222-689 & Vasalemma Quarry \\
\hline VASALEMMOCERAS TOLERABILE STUMBUR, 1962 & GIT 147-5a & Vasalemma \\
\hline \multicolumn{3}{|l|}{ total 13 specimens } \\
\hline BARRANDEOCERID indet & GIT 222-570 & Vasalemma Quarry \\
\hline \multicolumn{3}{|l|}{ total 1 specimen } \\
\hline HEMIBELOITOCERAS MOLIS sp. nov. & TUG 1585-32 & Rummu Quarry, Rummu 1 \\
\hline HEMIBELOITOCERAS MOLIS sp. nov. & TUG 1307-2a & Vasalemma Quarry \\
\hline HEMIBELOITOCERAS MOLIS sp. nov. & GIT 222-683 & Vasalemma \\
\hline HEMIBELOITOCERAS MOLIS sp. nov. & GIT 426-163 & Vasalemma Quarry \\
\hline HEMIBELOITOCERAS MOLIS sp. nov. & GIT 426-164 & Vasalemma Quarry \\
\hline HEMIBELOITOCERAS MOLIS sp. nov. & GIT 426-165 & Vasalemma Quarry \\
\hline HEMIBELOITOCERAS MOLIS sp. nov. & GIT 426-166 & Vasalemma Quarry \\
\hline HEMIBELOITOCERAS MOLIS sp. nov. & GIT 426-167 & Vasalemma Quarry \\
\hline \multicolumn{3}{|l|}{ total 8 specimens } \\
\hline HEMIBELOITOCERAS ARDUUM sp. nov. & TUG 1612-12 & Rummu Quarry, Rummu 2 \\
\hline HEMIBELOITOCERAS ARDUUM sp. nov. & TUG 1612-13 & Rummu Quarry, Rummu 2 \\
\hline HEMIBELOITOCERAS ARDUUM sp. nov. & TUG 1585-49 & Rummu Quarry, reef in Saku \\
\hline \multicolumn{3}{|l|}{ total 3 specimens } \\
\hline HEMIBELOITOCERAS sp. & TUG 1307-2b & Vasalemma Quarry \\
\hline HEMIBELOITOCERAS sp. & TUG 1612-14 & Rummu \\
\hline HEMIBELOITOCERAS sp. & GIT 222-671 & Vasalemma \\
\hline \multicolumn{3}{|l|}{ total 3 specimens } \\
\hline ISORTHOCERAS MARIS sp. nov. & TUG 1307-26 & Vasalemma Quarry \\
\hline ISORTHOCERAS MARIS sp. nov. & TUG 1393-16 & Vasalemma Quarry, reef 27 \\
\hline \multicolumn{3}{|l|}{ total 2 specimens } \\
\hline ISORTHOCERAS PADISENSE sp. nov. & TUG 1585-18 B & Rummu Quarry, Rummu 1 \\
\hline
\end{tabular}




\begin{tabular}{|c|c|c|}
\hline ISORTHOCERAS PADISENSE sp. nov. & TUG 1709-5 & Rummu Quarry, Rummu 1 \\
\hline \multicolumn{3}{|l|}{ total 2 specimens } \\
\hline ISORTHOCERAS CAVI sp. nov. & TUG 1585-23 & Rummu Quarry, Rummu 1 \\
\hline ISORTHOCERAS CAVI sp. nov. & TUG 1393-45 & Vasalemma \\
\hline ISORTHOCERAS CAVI sp. nov. & TUG 1393-22 & Vasalemma Quarry,I reef 42 \\
\hline ISORTHOCERAS CAVI sp. nov. & TUG 1585-25 & Rummu Quarry, Rummu 1 \\
\hline ISORTHOCERAS CAVI sp. nov. & TUG 1307-5 & Vasalemma Quarry \\
\hline ISORTHOCERAS CAVI sp. nov. & TUG 1585-41 & Rummu Quarry, Rummu 1 \\
\hline ISORTHOCERAS CAVI sp. nov. & GIT 222-637 & Vasalemma Quarry \\
\hline ISORTHOCERAS CAVI sp. nov. & GIT 222-653 & Vasalemma Quarry \\
\hline ISORTHOCERAS CAVI sp. nov. & GIT 222-664 & Vasalemma Quarry \\
\hline \multicolumn{3}{|l|}{ total 9 specimens } \\
\hline ISORTHOCERAS VEXILLI sp. nov. & TUG 939-11 & Vasalemma \\
\hline ISORTHOCERAS VEXILLI sp. nov. & TUG $1585-18 \mathrm{C}$ & Rummu Quarry, Rummu 1 \\
\hline ISORTHOCERAS VEXILLI sp. nov. & TUG 939-33 & Vasalemma \\
\hline \multicolumn{3}{|l|}{ total 3 specimens } \\
\hline $\begin{array}{l}\text { STRIATOCYCLOCERAS UNDULOSTRIATUM KRÖGER \& ISAKAR, } \\
2006\end{array}$ & TUG 939-24 & Vasalemma \\
\hline $\begin{array}{l}\text { STRIATOCYCLOCERAS UNDULOSTRIATUM KRÖGER \& ISAKAR, } \\
2006\end{array}$ & TUG 1393-15 & Vasalemma Quarry, reef 26 \\
\hline $\begin{array}{l}\text { STRIATOCYCLOCERAS UNDULOSTRIATUM KRÖGER \& ISAKAR, } \\
2006\end{array}$ & TUG 1585-19 & Rummu 1, Saku \\
\hline $\begin{array}{l}\text { STRIATOCYCLOCERAS UNDULOSTRIATUM KRÖGER \& ISAKAR, } \\
2006\end{array}$ & TUG 1307-4 & Vasalemma Quarry \\
\hline $\begin{array}{l}\text { STRIATOCYCLOCERAS UNDULOSTRIATUM KRÖGER \& ISAKAR, } \\
2006\end{array}$ & TUG 1307-3 A & Vasalemma Quarry \\
\hline $\begin{array}{l}\text { STRIATOCYCLOCERAS UNDULOSTRIATUM KRÖGER \& ISAKAR, } \\
2006\end{array}$ & TUG 1307-3 B & Vasalemma Quarry \\
\hline $\begin{array}{l}\text { STRIATOCYCLOCERAS UNDULOSTRIATUM KRÖGER \& ISAKAR, } \\
2006\end{array}$ & TUG $1307-3 \mathrm{C}$ & Vasalemma Quarry \\
\hline $\begin{array}{l}\text { STRIATOCYCLOCERAS UNDULOSTRIATUM KRÖGER \& ISAKAR, } \\
2006\end{array}$ & TUG 1307-3 D & Vasalemma Quarry \\
\hline $\begin{array}{l}\text { STRIATOCYCLOCERAS UNDULOSTRIATUM KRÖGER \& ISAKAR, } \\
2006\end{array}$ & TUG $1307-3 \mathrm{E}$ & Vasalemma Quarry \\
\hline $\begin{array}{l}\text { STRIATOCYCLOCERAS UNDULOSTRIATUM KRÖGER \& ISAKAR, } \\
2006\end{array}$ & TUG 1585-62 & Rummu Quarry, Rummu 1 \\
\hline $\begin{array}{l}\text { STRIATOCYCLOCERAS UNDULOSTRIATUM KRÖGER \& ISAKAR, } \\
2006\end{array}$ & TUG 1709-24 & $\begin{array}{l}\text { Rummu Quarry, Rummu 1, loose } \\
\text { blocks, reef facies }\end{array}$ \\
\hline $\begin{array}{l}\text { STRIATOCYCLOCERAS UNDULOSTRIATUM KRÖGER \& ISAKAR, } \\
2006\end{array}$ & TUG 1585-63 & Rummu Quarry, Rummu 1 \\
\hline $\begin{array}{l}\text { STRIATOCYCLOCERAS UNDULOSTRIATUM KRÖGER \& ISAKAR, } \\
2006\end{array}$ & TUG 1709-25 & Rummu Quarry, Rummu 1 \\
\hline $\begin{array}{l}\text { STRIATOCYCLOCERAS UNDULOSTRIATUM KRÖGER \& ISAKAR, } \\
2006\end{array}$ & TUG 1709-26 & Rummu Quarry, Rummu 1 \\
\hline $\begin{array}{l}\text { STRIATOCYCLOCERAS UNDULOSTRIATUM KRÖGER \& ISAKAR, } \\
2006\end{array}$ & TUG 1709-27 & $\begin{array}{l}\text { Rummu Quarry, Rummu 1, loose } \\
\text { blocks, reef facies }\end{array}$ \\
\hline $\begin{array}{l}\text { STRIATOCYCLOCERAS UNDULOSTRIATUM KRÖGER \& ISAKAR, } \\
2006\end{array}$ & TUG 1709-28 & $\begin{array}{l}\text { Rummu Quarry, Rummu 1, loose } \\
\text { blocks, reef facies }\end{array}$ \\
\hline
\end{tabular}




\begin{tabular}{|c|c|c|}
\hline $\begin{array}{l}\text { STRIATOCYCLOCERAS UNDULOSTRIATUM KRÖGER \& ISAKAR, } \\
2006\end{array}$ & TUG 1709-29 & Rummu Quarry, Rummu 1 \\
\hline $\begin{array}{l}\text { STRIATOCYCLOCERAS UNDULOSTRIATUM KRÖGER \& ISAKAR, } \\
2006\end{array}$ & TUG 1709-30 & Rummu Quarry, Rummu 1 \\
\hline $\begin{array}{l}\text { STRIATOCYCLOCERAS UNDULOSTRIATUM KRÖGER \& ISAKAR, } \\
2006\end{array}$ & TUG 1585-64 & Rummu Quarry, Rummu 1 \\
\hline $\begin{array}{l}\text { STRIATOCYCLOCERAS UNDULOSTRIATUM KRÖGER \& ISAKAR, } \\
2006\end{array}$ & TUG 1585-63 & Rummu Quarry, Rummu 1 \\
\hline $\begin{array}{l}\text { STRIATOCYCLOCERAS UNDULOSTRIATUM KRÖGER \& ISAKAR, } \\
2006\end{array}$ & TUG 1585-62 & Rummu Quarry, Rummu 1 \\
\hline $\begin{array}{l}\text { STRIATOCYCLOCERAS UNDULOSTRIATUM KRÖGER \& ISAKAR, } \\
2006\end{array}$ & TUG 1585-61 & Rummu Quarry, Rummu 1 \\
\hline $\begin{array}{l}\text { STRIATOCYCLOCERAS UNDULOSTRIATUM KRÖGER \& ISAKAR, } \\
2006\end{array}$ & GIT 222-599 & Vasalemma Quarry \\
\hline $\begin{array}{l}\text { STRIATOCYCLOCERAS UNDULOSTRIATUM KRÖGER \& ISAKAR, } \\
2006\end{array}$ & GIT 222-598 & Vasalemma Quarry \\
\hline $\begin{array}{l}\text { STRIATOCYCLOCERAS UNDULOSTRIATUM KRÖGER \& ISAKAR, } \\
2006\end{array}$ & GIT 222-597 & Vasalemma Quarry \\
\hline $\begin{array}{l}\text { STRIATOCYCLOCERAS UNDULOSTRIATUM KRÖGER \& ISAKAR, } \\
2006\end{array}$ & GIT 222-596 & Vasalemma Quarry \\
\hline $\begin{array}{l}\text { STRIATOCYCLOCERAS UNDULOSTRIATUM KRÖGER \& ISAKAR, } \\
2006\end{array}$ & GIT 222-595 & Vasalemma Quarry \\
\hline $\begin{array}{l}\text { STRIATOCYCLOCERAS UNDULOSTRIATUM KRÖGER \& ISAKAR, } \\
2006\end{array}$ & GIT 222-594 & Vasalemma Quarry \\
\hline $\begin{array}{l}\text { STRIATOCYCLOCERAS UNDULOSTRIATUM KRÖGER \& ISAKAR, } \\
2006\end{array}$ & GIT 222-593 & Vasalemma Quarry \\
\hline $\begin{array}{l}\text { STRIATOCYCLOCERAS UNDULOSTRIATUM KRÖGER \& ISAKAR, } \\
2006\end{array}$ & GIT 222-592 & Vasalemma Quarry \\
\hline $\begin{array}{l}\text { STRIATOCYCLOCERAS UNDULOSTRIATUM KRÖGER \& ISAKAR, } \\
2006\end{array}$ & GIT 222-591 & Vasalemma Quarry \\
\hline $\begin{array}{l}\text { STRIATOCYCLOCERAS UNDULOSTRIATUM KRÖGER \& ISAKAR, } \\
2006\end{array}$ & GIT 222-686 & Vasalemma \\
\hline $\begin{array}{l}\text { STRIATOCYCLOCERAS UNDULOSTRIATUM KRÖGER \& ISAKAR, } \\
2006\end{array}$ & GIT 222-438-1 & Vasalemma Quarry \\
\hline $\begin{array}{l}\text { STRIATOCYCLOCERAS UNDULOSTRIATUM KRÖGER \& ISAKAR, } \\
2006\end{array}$ & GIT 222-554 & Vasalemma Quarry \\
\hline $\begin{array}{l}\text { STRIATOCYCLOCERAS UNDULOSTRIATUM KRÖGER \& ISAKAR, } \\
2006\end{array}$ & GIT 222-666 & Vasalemma Quarry \\
\hline $\begin{array}{l}\text { STRIATOCYCLOCERAS UNDULOSTRIATUM KRÖGER \& ISAKAR, } \\
2006\end{array}$ & GIT 222-97 & Vasalemma Quarry \\
\hline $\begin{array}{l}\text { STRIATOCYCLOCERAS UNDULOSTRIATUM KRÖGER \& ISAKAR, } \\
2006\end{array}$ & GIT 222-600-1 & Vasalemma Quarry \\
\hline $\begin{array}{l}\text { STRIATOCYCLOCERAS UNDULOSTRIATUM KRÖGER \& ISAKAR, } \\
2006\end{array}$ & GIT 222-600-2 & Vasalemma Quarry \\
\hline $\begin{array}{l}\text { STRIATOCYCLOCERAS UNDULOSTRIATUM KRÖGER \& ISAKAR, } \\
2006\end{array}$ & GIT 222-609 & Vasalemma Quarry \\
\hline $\begin{array}{l}\text { STRIATOCYCLOCERAS UNDULOSTRIATUM KRÖGER \& ISAKAR, } \\
2006\end{array}$ & GIT 222-608 & Vasalemma Quarry \\
\hline $\begin{array}{l}\text { STRIATOCYCLOCERAS UNDULOSTRIATUM KRÖGER \& ISAKAR, } \\
2006\end{array}$ & GIT 222-607 & Vasalemma Quarry \\
\hline
\end{tabular}




\begin{tabular}{|c|c|c|}
\hline $\begin{array}{l}\text { STRIATOCYCLOCERAS UNDULOSTRIATUM KRÖGER \& ISAKAR, } \\
2006\end{array}$ & GIT 222-606 & Vasalemma Quarry \\
\hline $\begin{array}{l}\text { STRIATOCYCLOCERAS UNDULOSTRIATUM KRÖGER \& ISAKAR, } \\
2006\end{array}$ & GIT 222-605 & Vasalemma Quarry \\
\hline $\begin{array}{l}\text { STRIATOCYCLOCERAS UNDULOSTRIATUM KRÖGER \& ISAKAR, } \\
2006\end{array}$ & GIT 222-604 & Vasalemma Quarry \\
\hline $\begin{array}{l}\text { STRIATOCYCLOCERAS UNDULOSTRIATUM KRÖGER \& ISAKAR, } \\
2006\end{array}$ & GIT 222-603 & Vasalemma Quarry \\
\hline $\begin{array}{l}\text { STRIATOCYCLOCERAS UNDULOSTRIATUM KRÖGER \& ISAKAR, } \\
2006\end{array}$ & GIT 222-602 & Vasalemma Quarry \\
\hline $\begin{array}{l}\text { STRIATOCYCLOCERAS UNDULOSTRIATUM KRÖGER \& ISAKAR, } \\
2006\end{array}$ & GIT 222-601 & Vasalemma Quarry \\
\hline \multicolumn{3}{|l|}{ total 51 specimens } \\
\hline RUMMOCERAS RUMMUENSIS gen. et sp. nov. & TUG 1709-31 & Rummu Quarry, Rummu 1 \\
\hline \multicolumn{3}{|l|}{ total 1 specimen } \\
\hline PLEURORTHOCERAS ORGANI sp. nov. & TUG 1307-27 & Vasalemma Quarry \\
\hline PLEURORTHOCERAS ORGANI sp. nov. & TUG 939-84a & Vasalemma \\
\hline PLEURORTHOCERAS ORGANI sp. nov. & TUG 939-84b & Vasalemma \\
\hline PLEURORTHOCERAS ORGANI sp. nov. & TUG 939-84c & Vasalemma \\
\hline PLEURORTHOCERAS ORGANI sp. nov. & GIT 222-536-2 & Vasalemma \\
\hline \multicolumn{3}{|l|}{ total 5 specimens } \\
\hline ORDOGEISONOCERAS? sp. & TUG 939-8 & Vasalemma \\
\hline ORDOGEISONOCERAS? sp. & TUG 939-9a & Vasalemma \\
\hline \multicolumn{3}{|l|}{ total 2 specimens } \\
\hline ORDOGEISONOCERAS TARTUENSIS sp. nov. & TUG 939-10 & Vasalemma \\
\hline ORDOGEISONOCERAS TARTUENSIS sp. nov. & TUG 939-1065a & Vasalemma \\
\hline ORDOGEISONOCERAS TARTUENSIS sp. nov. & TUG 939-1065b & Vasalemma \\
\hline ORDOGEISONOCERAS TARTUENSIS sp. nov. & TUG 939-1065c & Vasalemma \\
\hline ORDOGEISONOCERAS TARTUENSIS sp. nov. & TUG 939-1065d & Vasalemma \\
\hline ORDOGEISONOCERAS TARTUENSIS sp. nov. & TUG 939-1065e & Vasalemma \\
\hline ORDOGEISONOCERAS TARTUENSIS sp. nov. & GIT 222-667 & Vasalemma Quarry \\
\hline \multicolumn{3}{|l|}{ total 7 specimens } \\
\hline ORTHONYBYOCERAS cf. DYERI (miller, 1875) & TUG 1307-1 & Vasalemma Quarry \\
\hline ORTHONYBYOCERAS cf. DYERI (miller, 1875) & TUG 1709-32 & Rummu Quarry, Rummu 1 \\
\hline ORTHONYBYOCERAS cf. DYERI (miller, 1875) & TUG 939-35 & Vasalemma \\
\hline ORTHONYBYOCERAS cf. DYERI (miller, 1875) & TUG 1709-33 & Rummu Quarry, Rummu 1 \\
\hline ORTHONYBYOCERAS cf. DYERI (miller, 1875) & TUG 939-36 & Rummu Quarry, Rummu 1 \\
\hline ORTHONYBYOCERAS cf. DYERI (miller, 1875) & TUG 1307-6 & Vasalemma Quarry \\
\hline ORTHONYBYOCERAS cf. DYERI (miller, 1875) & TUG 1393-46 & Vasalemma Quarry, reef 42 \\
\hline ORTHONYBYOCERAS cf. DYERI (miller, 1875) & TUG 1393-47 & Vasalemma Quarry, reef 42 \\
\hline ORTHONYBYOCERAS cf. DYERI (miller, 1875) & TUG 1709-34 & Rummu Quarry, Rummu 1 \\
\hline ORTHONYBYOCERAS cf. DYERI (miller, 1875) & TUG 1585-18a & Rummu Quarry, Saku \\
\hline ORTHONYBYOCERAS cf. DYERI (miller, 1875) & TUG 939-42 & Vasalemma \\
\hline ORTHONYBYOCERAS cf. DYERI (miller, 1875) & TUG 939-83 & Vasalemma \\
\hline ORTHONYBYOCERAS cf. DYERI (miller, 1875) & TUG 1709-3a & Rummu Quarry, Rummu 1 \\
\hline
\end{tabular}




\begin{tabular}{|c|c|c|}
\hline ORTHONYBYOCERAS cf. DYERI (miller, 1875) & TUG 1709-3b & Rummu Quarry, Rummu 1 \\
\hline ORTHONYBYOCERAS cf. DYERI (miller, 1875) & TUG 100-6a & Vasalemma \\
\hline ORTHONYBYOCERAS cf. DYERI (miller, 1875) & TUG 100-6b & Vasalemma \\
\hline ORTHONYBYOCERAS cf. DYERI (miller, 1875) & TUG 939-31 & Vasalemma \\
\hline ORTHONYBYOCERAS cf. DYERI (miller, 1875) & TUG 939-39 & Vasalemma \\
\hline ORTHONYBYOCERAS cf. DYERI (miller, 1875) & TUG 939-43 & Vasalemma \\
\hline ORTHONYBYOCERAS cf. DYERI (miller, 1875) & TUG 939-46 & Vasalemma \\
\hline ORTHONYBYOCERAS cf. DYERI (miller, 1875) & TUG 1709-35 & Rummu Quarry, Rummu 1 \\
\hline ORTHONYBYOCERAS cf. DYERI (miller, 1875) & TUG 939-40 & Vasalemma \\
\hline ORTHONYBYOCERAS cf. DYERI (miller, 1875) & TUG 1709-20 & Rummu Quarry, Rummu 1 \\
\hline ORTHONYBYOCERAS cf. DYERI (miller, 1875) & TUG 1307-6 & Vasalemma quarry \\
\hline ORTHONYBYOCERAS cf. DYERI (miller, 1875) & TUG 1393-34 & $\begin{array}{l}\text { Vasalemma Quarry, reef } 42, \\
\text { cephalopod cave }\end{array}$ \\
\hline ORTHONYBYOCERAS cf. DYERI (miller, 1875) & TUG 1307-31 & Vasalemma Quarry \\
\hline ORTHONYBYOCERAS cf. DYERI (miller, 1875) & TUG 1393-30 & $\begin{array}{l}\text { Vasalemma Quarry, reef } 42 \text {, } \\
\text { cephalopod cave }\end{array}$ \\
\hline ORTHONYBYOCERAS cf. DYERI (miller, 1875) & TUG 1709-18a & Rummu Quarry, Rummu 1 \\
\hline ORTHONYBYOCERAS cf. DYERI (miller, 1875) & TUG 1709-18b & Rummu Quarry, Rummu 1 \\
\hline ORTHONYBYOCERAS cf. DYERI (miller, 1875) & TUG 1709-18c & Rummu Quarry, Rummu 1 \\
\hline ORTHONYBYOCERAS cf. DYERI (miller, 1875) & TUG 1709-21 & Rummu Quarry, Rummu 1 \\
\hline ORTHONYBYOCERAS cf. DYERI (miller, 1875) & TUG 1585-44 & Rummu Quarry, Rummu 1 \\
\hline ORTHONYBYOCERAS cf. DYERI (miller, 1875) & TUG 1585-48a & Rummu 1, Saku fissure in reef \\
\hline ORTHONYBYOCERAS cf. DYERI (miller, 1875) & TUG1585-48b & Rummu 1, Saku fissure in reef \\
\hline ORTHONYBYOCERAS cf. DYERI (miller, 1875) & TUG 1585-48c & Rummu 1, Saku fissure in reef \\
\hline ORTHONYBYOCERAS cf. DYERI (miller, 1875) & TUG 1585-47 & Rummu Quarry, Rummu 1 \\
\hline ORTHONYBYOCERAS cf. DYERI (miller, 1875) & TUG1393-31 & $\begin{array}{l}\text { Vasalemma Quarry, reef } 42 \text {, } \\
\text { cephalopod cave }\end{array}$ \\
\hline ORTHONYBYOCERAS cf. DYERI (miller, 1875) & TUG 1644-56b & Vasalemma \\
\hline ORTHONYBYOCERAS cf. DYERI (miller, 1875) & TUG 1644-56c & Vasalemma \\
\hline ORTHONYBYOCERAS cf. DYERI (miller, 1875) & TUG 1644-56d & Vasalemma \\
\hline ORTHONYBYOCERAS cf. DYERI (miller, 1875) & TUG 1585-46 & $\begin{array}{l}\text { Rummu Quarry, Rummu 1, Saku } \\
\text { reef }\end{array}$ \\
\hline ORTHONYBYOCERAS cf. DYERI (miller, 1875) & TUG 1709-17a & $\begin{array}{l}\text { Rummu Quarry, Rummu 1, reef } \\
\text { facies }\end{array}$ \\
\hline ORTHONYBYOCERAS cf. DYERI (miller, 1875) & TUG 1709-17b & $\begin{array}{l}\text { Rummu Quarry, Rummu 1, reef } \\
\text { facies }\end{array}$ \\
\hline ORTHONYBYOCERAS cf. DYERI (miller, 1875) & TUG 1393-33 & $\begin{array}{l}\text { Vasalemma Quarry, reef } 42, \\
\text { cephalopod cave }\end{array}$ \\
\hline ORTHONYBYOCERAS cf. DYERI (miller, 1875) & TUG 1585-43 & Rummu Quarry, Rummu 1 \\
\hline ORTHONYBYOCERAS cf. DYERI (miller, 1875) & TUG 1709-19 & Rummu Quarry, Rummu 1 \\
\hline ORTHONYBYOCERAS cf. DYERI (miller, 1875) & TUG 1585-45 & Rummu Quarry, Rummu 1 \\
\hline ORTHONYBYOCERAS cf. DYERI (miller, 1875) & TUG 1393-36 & $\begin{array}{l}\text { Vasalemma Quarry, reef } 42, \\
\text { cephalopod cave }\end{array}$ \\
\hline ORTHONYBYOCERAS cf. DYERI (miller, 1875) & TUG 1393-28 & Vasalemma Quarry, reef 27 \\
\hline ORTHONYBYOCERAS cf. DYERI (miller, 1875) & TUG 1393-29 & $\begin{array}{l}\text { Vasalemma Quarry, reef } 42, \\
\text { cephalopod cave }\end{array}$ \\
\hline
\end{tabular}




\begin{tabular}{|c|c|c|}
\hline ORTHONYBYOCERAS cf. DYERI (miller, 1875) & TUG 1709-16 & Rummu Quarry, Rummu 1 \\
\hline ORTHONYBYOCERAS cf. DYERI (miller, 1875) & GIT 222-652-1 & Vasalemma Quarry \\
\hline ORTHONYBYOCERAS cf. DYERI (miller, 1875) & GIT 222-652-2 & Vasalemma Quarry \\
\hline ORTHONYBYOCERAS cf. DYERI (miller, 1875) & GIT 222-672 & Vasalemma \\
\hline ORTHONYBYOCERAS cf. DYERI (miller, 1875) & GIT 222-673 & Vasalemma \\
\hline ORTHONYBYOCERAS cf. DYERI (miller, 1875) & GIT 222-694 & Vasalemma \\
\hline ORTHONYBYOCERAS cf. DYERI (miller, 1875) & GIT 222-693 & Vasalemma \\
\hline ORTHONYBYOCERAS cf. DYERI (miller, 1875) & GIT 222-692 & Vasalemma \\
\hline ORTHONYBYOCERAS cf. DYERI (miller, 1875) & GIT 222-691 & Vasalemma \\
\hline ORTHONYBYOCERAS cf. DYERI (miller, 1875) & GIT 222-690 & Vasalemma \\
\hline ORTHONYBYOCERAS cf. DYERI (miller, 1875) & GIT 222-674 & Vasalemma \\
\hline ORTHONYBYOCERAS cf. DYERI (miller, 1875) & GIT 222-675 & Vasalemma \\
\hline ORTHONYBYOCERAS cf. DYERI (miller, 1875) & GIT 222-636 & Vasalemma Quarry \\
\hline ORTHONYBYOCERAS cf. DYERI (miller, 1875) & GIT 222-635 & Vasalemma Quarry \\
\hline ORTHONYBYOCERAS cf. DYERI (miller, 1875) & GIT 222-634 & Vasalemma Quarry \\
\hline ORTHONYBYOCERAS cf. DYERI (miller, 1875) & GIT 222-633 & Vasalemma Quarry \\
\hline ORTHONYBYOCERAS cf. DYERI (miller, 1875) & GIT 222-617 & Vasalemma Quarry \\
\hline ORTHONYBYOCERAS cf. DYERI (miller, 1875) & GIT 222-616 & Vasalemma Quarry \\
\hline ORTHONYBYOCERAS cf. DYERI (miller, 1875) & GIT 222-615 & Vasalemma Quarry \\
\hline ORTHONYBYOCERAS cf. DYERI (miller, 1875) & GIT 222-649 & Vasalemma Quarry \\
\hline ORTHONYBYOCERAS cf. DYERI (miller, 1875) & GIT 222-648 & Vasalemma Quarry \\
\hline ORTHONYBYOCERAS cf. DYERI (miller, 1875) & GIT 222-647 & Vasalemma Quarry \\
\hline ORTHONYBYOCERAS cf. DYERI (miller, 1875) & GIT 222-646 & Vasalemma Quarry \\
\hline ORTHONYBYOCERAS cf. DYERI (miller, 1875) & GIT 222-645 & Vasalemma Quarry \\
\hline ORTHONYBYOCERAS cf. DYERI (miller, 1875) & GIT 222-644 & Vasalemma Quarry \\
\hline ORTHONYBYOCERAS cf. DYERI (miller, 1875) & GIT 222-643 & Vasalemma Quarry \\
\hline ORTHONYBYOCERAS cf. DYERI (miller, 1875) & GIT 222-642 & Vasalemma Quarry \\
\hline ORTHONYBYOCERAS cf. DYERI (miller, 1875) & GIT 222-641 & Vasalemma Quarry \\
\hline ORTHONYBYOCERAS cf. DYERI (miller, 1875) & GIT 222-640 & Vasalemma Quarry \\
\hline ORTHONYBYOCERAS cf. DYERI (miller, 1875) & GIT 222-639 & Vasalemma Quarry \\
\hline ORTHONYBYOCERAS cf. DYERI (miller, 1875) & GIT 222-638 & Vasalemma Quarry \\
\hline ORTHONYBYOCERAS cf. DYERI (miller, 1875) & GIT 222-650 & Vasalemma Quarry \\
\hline ORTHONYBYOCERAS cf. DYERI (miller, 1875) & GIT 222-580 & Vasalemma Quarry \\
\hline ORTHONYBYOCERAS cf. DYERI (miller, 1875) & GIT 222-584-5 & Vasalemma Quarry \\
\hline ORTHONYBYOCERAS cf. DYERI (miller, 1875) & GIT 222-586-1 & Vasalemma Quarry \\
\hline ORTHONYBYOCERAS cf. DYERI (miller, 1875) & GIT 222-586-2 & Vasalemma Quarry \\
\hline ORTHONYBYOCERAS cf. DYERI (miller, 1875) & GIT 222-630 & Vasalemma Quarry \\
\hline ORTHONYBYOCERAS cf. DYERI (miller, 1875) & GIT 222-631 & Vasalemma Quarry \\
\hline ORTHONYBYOCERAS cf. DYERI (miller, 1875) & GIT 222-632 & Vasalemma Quarry \\
\hline ORTHONYBYOCERAS cf. DYERI (miller, 1875) & GIT 222-665 & Vasalemma Quarry \\
\hline ORTHONYBYOCERAS cf. DYERI (miller, 1875) & GIT 222-577 & Vasalemma Quarry \\
\hline ORTHONYBYOCERAS cf. DYERI (miller, 1875) & GIT 222-676 & Vasalemma Quarry \\
\hline ORTHONYBYOCERAS cf. DYERI (miller, 1875) & GIT 222-677 & Vasalemma Quarry \\
\hline
\end{tabular}




\begin{tabular}{|c|c|c|}
\hline ORTHONYBYOCERAS cf. DYERI (miller, 1875) & GIT 222-547 & Vasalemma Quarry \\
\hline ORTHONYBYOCERAS cf. DYERI (miller, 1875) & GIT 222-682 & Vasalemma \\
\hline ORTHONYBYOCERAS cf. DYERI (miller, 1875) & GIT 222-681 & Vasalemma \\
\hline ORTHONYBYOCERAS cf. DYERI (miller, 1875) & GIT 222-680 & Vasalemma \\
\hline ORTHONYBYOCERAS cf. DYERI (miller, 1875) & GIT 222-679 & Vasalemma \\
\hline ORTHONYBYOCERAS cf. DYERI (miller, 1875) & GIT 222-57 & Vasalemma Quarry \\
\hline \multicolumn{3}{|l|}{ total 99 specimens } \\
\hline ORTHONYBYOCERAS ISAKARI sp. nov. & TUG 1393-48 & Vasalemma Quarry, reef 42 \\
\hline ORTHONYBYOCERAS ISAKARI sp. nov. & TUG 939-1180a & Vasalemma \\
\hline ORTHONYBYOCERAS ISAKARI sp. nov. & TUG 1709-36 & Rummu Quarry, Rummu 1 \\
\hline ORTHONYBYOCERAS ISAKARI sp. nov. & TUG 1307-32 & Vasalemma \\
\hline ORTHONYBYOCERAS ISAKARI sp. nov. & TUG 1585-68 & Rummu Quarry, Rummu 1 \\
\hline ORTHONYBYOCERAS ISAKARI sp. nov. & TUG 1393-19 & Vasalemma Quarry, reef 42 \\
\hline ORTHONYBYOCERAS ISAKARI sp. nov. & TUG 100-7 & Vasalemma \\
\hline ORTHONYBYOCERAS ISAKARI sp. nov. & TUG 100-8a & Vasalemma \\
\hline ORTHONYBYOCERAS ISAKARI sp. nov. & TUG 100-8b & Vasalemma \\
\hline ORTHONYBYOCERAS ISAKARI sp. nov. & TUG 1393-21 & Vasalemma Quarry, reef 42 \\
\hline ORTHONYBYOCERAS ISAKARI sp. nov. & TUG 1307-33 & Vasalemma \\
\hline ORTHONYBYOCERAS ISAKARI sp. nov. & TUG 939-38 & Vasalemma \\
\hline ORTHONYBYOCERAS ISAKARI sp. nov. & TUG 1585-21 & Rummu Quarry, Rummu 1 \\
\hline ORTHONYBYOCERAS ISAKARI sp. nov. & TUG 939-45 & Vasalemma \\
\hline ORTHONYBYOCERAS ISAKARI sp. nov. & TUG 1709-37 & Rummu Quarry, Rummu 1 \\
\hline ORTHONYBYOCERAS ISAKARI sp. nov. & TUG 1585-22 & Rummu Quarry, Rummu 1 \\
\hline ORTHONYBYOCERAS ISAKARI sp. nov. & TUG 1709-38 & Rummu Quarry, Rummu 1 \\
\hline ORTHONYBYOCERAS ISAKARI sp. nov. & TUG 1709-39 & Rummu Quarry, Rummu 1 \\
\hline ORTHONYBYOCERAS ISAKARI sp. nov. & TUG 1585-24 & Rummu Quarry, Rummu 1 \\
\hline ORTHONYBYOCERAS ISAKARI sp. nov. & TUG 1709-4 & Rummu Quarry, Rummu 1 \\
\hline ORTHONYBYOCERAS ISAKARI sp. nov. & TUG 939-37 & Vasalemma \\
\hline ORTHONYBYOCERAS ISAKARI sp. nov. & TUG 1585-26a & Rummu Quarry, Rummu 1 \\
\hline ORTHONYBYOCERAS ISAKARI sp. nov. & TUG 1585-26b & Rummu Quarry, Rummu 1 \\
\hline ORTHONYBYOCERAS ISAKARI sp. nov. & TUG $1585-26 \mathrm{c}$ & Rummu Quarry, Rummu 1 \\
\hline ORTHONYBYOCERAS ISAKARI sp. nov. & TUG 1709-23 & Rummu Quarry, Rummu 1 \\
\hline ORTHONYBYOCERAS ISAKARI sp. nov. & TUG 1589-50 & Rummu Quarry, Rummu 1 \\
\hline ORTHONYBYOCERAS ISAKARI sp. nov. & TUG 1585-52 & Rummu Quarry, Rummu 1 \\
\hline ORTHONYBYOCERAS ISAKARI sp. nov. & TUG 1393-40 & $\begin{array}{l}\text { Vasalemma Quarry, reef } 42, \\
\text { cephalopod cave }\end{array}$ \\
\hline ORTHONYBYOCERAS ISAKARI sp. nov. & TUG 1393-38 & $\begin{array}{l}\text { Vasalemma Quarry, reef } 42, \\
\text { cephalopod cave }\end{array}$ \\
\hline ORTHONYBYOCERAS ISAKARI sp. nov. & TUG 1393-32 & $\begin{array}{l}\text { Vasalemma Quarry, reef } 42, \\
\text { cephalopod cave }\end{array}$ \\
\hline ORTHONYBYOCERAS ISAKARI sp. nov. & TUG 1585-51 & Rummu Quarry, Rummu 1 \\
\hline ORTHONYBYOCERAS ISAKARI sp. nov. & TUG 1393-41 & $\begin{array}{l}\text { Vasalemma Quarry, reef } 42, \\
\text { cephalopod cave }\end{array}$ \\
\hline ORTHONYBYOCERAS ISAKARI sp. nov. & TUG 1393-37 & $\begin{array}{l}\text { Vasalemma Quarry, reef } 42 \text {, } \\
\text { cephalopod cave }\end{array}$ \\
\hline
\end{tabular}




\begin{tabular}{|c|c|c|}
\hline ORTHONYBYOCERAS ISAKARI sp. nov. & TUG 1585-59-1 & \\
\hline ORTHONYBYOCERAS ISAKARI sp. nov. & TUG 1585-59-2 & \\
\hline ORTHONYBYOCERAS ISAKARI sp. nov. & TUG 1585-57 & Rummu Quarry, Rummu 1 \\
\hline ORTHONYBYOCERAS ISAKARI sp. nov. & TUG 1585-60 & $\begin{array}{l}\text { Rummu Quarry, Rummu 1, reef in } \\
\text { Saku }\end{array}$ \\
\hline ORTHONYBYOCERAS ISAKARI sp. nov. & TUG 1393-39 & $\begin{array}{l}\text { Vasalemma Quarry, reef } 42, \\
\text { cephalopod cave }\end{array}$ \\
\hline ORTHONYBYOCERAS ISAKARI sp. nov. & TUG 1709-22 & Rummu Quarry, Rummu 1 \\
\hline ORTHONYBYOCERAS ISAKARI sp. nov. & TUG 1585-53 & $\begin{array}{l}\text { Rummu Quarry, Rummu 1, reef in } \\
\text { Saku }\end{array}$ \\
\hline ORTHONYBYOCERAS ISAKARI sp. nov. & TUG 1585-58 & $\begin{array}{l}\text { Rummu Quarry, Rummu 1, reef in } \\
\text { Saku }\end{array}$ \\
\hline ORTHONYBYOCERAS ISAKARI sp. nov. & TUG 1585-54 & Rummu Quarry, Rummu 1 \\
\hline ORTHONYBYOCERAS ISAKARI sp. nov. & TUG 1585-56 & Rummu Quarry, Rummu 1 \\
\hline ORTHONYBYOCERAS ISAKARI sp. nov. & TUG 1585-55 & Rummu Quarry, Rummu 1 \\
\hline ORTHONYBYOCERAS ISAKARI sp. nov. & TUG 1644-56 & Rummu Quarry, flank of reef \\
\hline ORTHONYBYOCERAS ISAKARI sp. nov. & TUG 1393-35 & $\begin{array}{l}\text { Vasalemma Quarry, reef } 42 \text {, } \\
\text { cephalopod cave }\end{array}$ \\
\hline ORTHONYBYOCERAS ISAKARI sp. nov. & GIT 222-613 & Vasalemma Quarry \\
\hline ORTHONYBYOCERAS ISAKARI sp. nov. & GIT 222-550 & Vasalemma Quarry \\
\hline ORTHONYBYOCERAS ISAKARI sp. nov. & GIT 222-657 & Vasalemma Quarry \\
\hline ORTHONYBYOCERAS ISAKARI sp. nov. & GIT 222-678 & Vasalemma \\
\hline ORTHONYBYOCERAS ISAKARI sp. nov. & GIT 222-641 & Vasalemma Quarry \\
\hline ORTHONYBYOCERAS ISAKARI sp. nov. & GIT 222-660 & Vasalemma Quarry \\
\hline ORTHONYBYOCERAS ISAKARI sp. nov. & GIT 222-659 & Vasalemma Quarry \\
\hline ORTHONYBYOCERAS ISAKARI sp. nov. & GIT 222-662 & Vasalemma Quarry \\
\hline ORTHONYBYOCERAS ISAKARI sp. nov. & GIT 222-582 & Vasalemma Quarry \\
\hline ORTHONYBYOCERAS ISAKARI sp. nov. & GIT 222-583 & Vasalemma Quarry \\
\hline ORTHONYBYOCERAS ISAKARI sp. nov. & GIT 222-619 & Vasalemma Quarry \\
\hline ORTHONYBYOCERAS ISAKARI sp. nov. & GIT 222-620 & Vasalemma Quarry \\
\hline ORTHONYBYOCERAS ISAKARI sp. nov. & GIT 222-612 & Vasalemma Quarry \\
\hline ORTHONYBYOCERAS ISAKARI sp. nov. & GIT 222-572 & Vasalemma Quarry \\
\hline ORTHONYBYOCERAS ISAKARI sp. nov. & GIT 222-687 & Vasalemma \\
\hline ORTHONYBYOCERAS ISAKARI sp. nov. & GIT 222-688 & Vasalemma \\
\hline ORTHONYBYOCERAS ISAKARI sp. nov. & GIT 222-573 & Vasalemma Quarry \\
\hline ORTHONYBYOCERAS ISAKARI sp. nov. & GIT 222-684 & Vasalemma \\
\hline ORTHONYBYOCERAS ISAKARI sp. nov. & GIT 222-610 & Vasalemma \\
\hline \multicolumn{3}{|l|}{ total 65 specimens } \\
\hline ORTHONYBYOCERAS MOISENSE SP. nOV. & TUG 1393-49 & Vasalemma Quarry, reef 42 \\
\hline ORTHONYBYOCERAS MOISENSE sp. nov. & TUG 939-44 & Vasalemma \\
\hline ORTHONYBYOCERAS MOISENSE Sp. nOV. & TUG 1393-26 & $\begin{array}{l}\text { Vasalemma Quarry, reef } 42, \\
\text { cephalopod cave }\end{array}$ \\
\hline ORTHONYBYOCERAS MOISENSE sp. nOV. & TUG 1585-42 & Rummu Quarry, Rummu 1 \\
\hline ORTHONYBYOCERAS MOISENSE sp. nov. & TUG 1393-27 & $\begin{array}{l}\text { Vasalemma Quarry, reef } 27, \\
\text { cephalopod cave }\end{array}$ \\
\hline
\end{tabular}




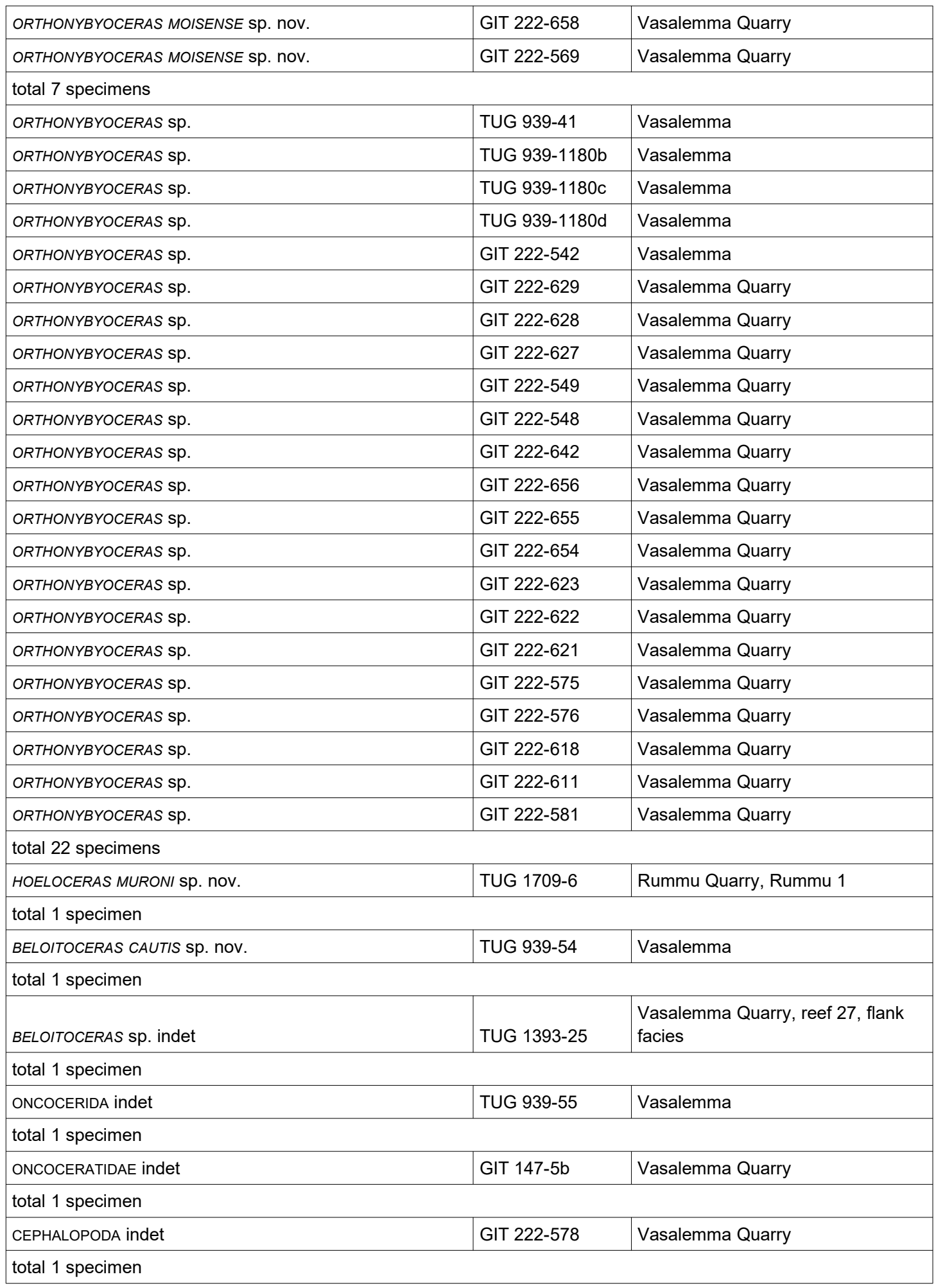

Data Supplement 3. Diversity estimates of the cephalopod assemblage of the Vasalemma Formation compared with other Ordovician cephalopod assemblages from reef settings. Note the high taxonomic distinctness of the Vasalemma cephalopods. S rarified based on rarefaction function in Oksanen et al. (2013); $\mathrm{S}_{\mathrm{SQs}}$ based on Shareholder Quorum Subsampling (Alroy, 2010); $\mathrm{J}=\mathrm{H} / \log (\mathrm{S})=\log ; \Delta$ after Clarke \& Warwick, 1999. Data: ${ }^{\circ}$ from Kröger \& Ebbestad (2014); * from Kröger \& Landing (2009); " from Kröger \& Landing (2007). 


\begin{tabular}{|l|l|l|l|l|}
\hline & $\begin{array}{l}\text { Boda Limestone } \\
\text { Formation } \\
\text { (late Katian- } \\
\text { early } \\
\text { Hirnantian) }\end{array}$ & $\begin{array}{l}\text { Vasalemma } \\
\text { Formation } \\
\text { (late Sandbian) }\end{array}$ & $\begin{array}{l}\text { Fort Cassin } \\
\text { Formation } \\
\text { (early-mid } \\
\text { Floian) }^{*}\end{array}$ & $\begin{array}{l}\text { Tribes Hill } \\
\text { Formation } \\
\text { (early } \\
\text { Tremadocian) }\end{array}$ \\
\hline $\begin{array}{l}\text { Raw richness } \\
(\mathrm{S})\end{array}$ & 63 & 19 & 13 & 11 \\
\hline Sample size $(\mathrm{N})$ & 543 & 282 & 72 & 222 \\
\hline S $_{\text {rarified }}$ & 30 & 12 & $-/-$ & 6 \\
\hline SsQS & 41 & 9 & $-/-$ & 3 \\
\hline $\begin{array}{l}\text { Shannon-Index } \\
(\mathrm{H})\end{array}$ & 3.42 & 1.94 & 1.68 & 1.37 \\
\hline $\begin{array}{l}\text { Pielou's } \\
\text { evenness }(\mathrm{J})\end{array}$ & 0.83 & 0.66 & 0.66 & 0.57 \\
\hline $\begin{array}{l}\text { Taxonomic } \\
\text { distinctness }(\Delta)\end{array}$ & 3.66 & 3.75 & 3.67 & 1.2 \\
\hline
\end{tabular}

Data Supplement 4. Counts of cephalopod specimens of the Vasalemma Formation with epizoans.

\begin{tabular}{|l|l|l|l|l|}
\hline & Sample Size & $\begin{array}{l}\text { N with } \\
\text { epizoans }\end{array}$ & $\begin{array}{l}\text { N with } \\
\text { bryozoans }\end{array}$ & $\begin{array}{l}\text { N with } \\
\text { echinoderm } \\
\text { holdfasts }\end{array}$ \\
\hline Actinocerida & 106 & 5 & 4 & 1 \\
\hline Discosorida & 7 & 3 & 1 & 1 \\
\hline Oncocerida & 5 & 2 & 2 & 0 \\
\hline Orthocerida & 48 & 9 & 8 & 1 \\
\hline Tarphycerida & 29 & 9 & 9 & 0 \\
\hline indet & 3 & 2 & 2 & 0 \\
\hline
\end{tabular}

